\title{
ANÁliSE REGULATÓRIA DA PARTICIPAÇÃO DA ENERGIA SOLAR FOTOVOLTAICA E ESTUDO DO MELHOR MECANISMO DE SUPORTE PARA INSERI-LA NA MATRIZ ELÉTRICA BRASILEIRA
}

\section{HELENA MAGALHÃES MIAN}

DISSERTAÇÃO DE MESTRADO EM ENGENHARIA ELÉTRICA

Brasília, maio de 2015

\section{UNIVERSIDADE DE BRASÍLIA}

\author{
FACULDADE DE TECNOLOGIA
}


UNIVERSIDADE DE BRASÍLIA

FACULDADE DE TECNOLOGIA

DEPARTAMENTO DE ENGENHARIA ELÉTRICA

\begin{abstract}
ANÁliSE REGULATÓRIA DA PARTICIPAÇÃO DA ENERGIA SOLAR FOTOVOLTAICA E ESTUDO DO MELHOR MECANISMO DE SUPORTE PARA INSERI-LA NA MATRIZ ELÉTRICA BRASILEIRA
\end{abstract} HELENA MAGALHÃES MIAN ORIENTADOR: RAFAEL AMARAL SHAYANI

DISSERTAÇÃO DE MESTRADO EM ENGENHARIA ELÉTRICA PUBLICAÇÃO: PPGEE.DM - 592/15 BRASÍLIA/DF: MAIO - 2015 


\section{UNIVERSIDADE DE BRASÍLIA \\ FACULDADE DE TECNOLOGIA DEPARTAMENTO DE ENGENHARIA ELÉTRICA}

\section{ANÁLISE REGULATÓRIA DA PARTICIPAÇÃO DA ENERGIA SOLAR FOTOVOLTAICA E ESTUDO DO MELHOR MECANISMO DE SUPORTE PARA INSERI-LA NA MATRIZ ELÉTRICA BRASILEIRA}

\section{HELENA MAGALHÃES MIAN}

DISSERTAÇÃO DE MESTRADO SUBMETIDA AO DEPARTAMENTO DE ENGENHARIA ELÉTRICA DA FACULDADE DE TECNOLOGIA DA UNIVERSIDADE DE BRASÍLIA, COMO PARTE DOS REQUISITOS NECESSÁRIOS PARA A OBTENÇÃO DO GRAU DE MESTRE.

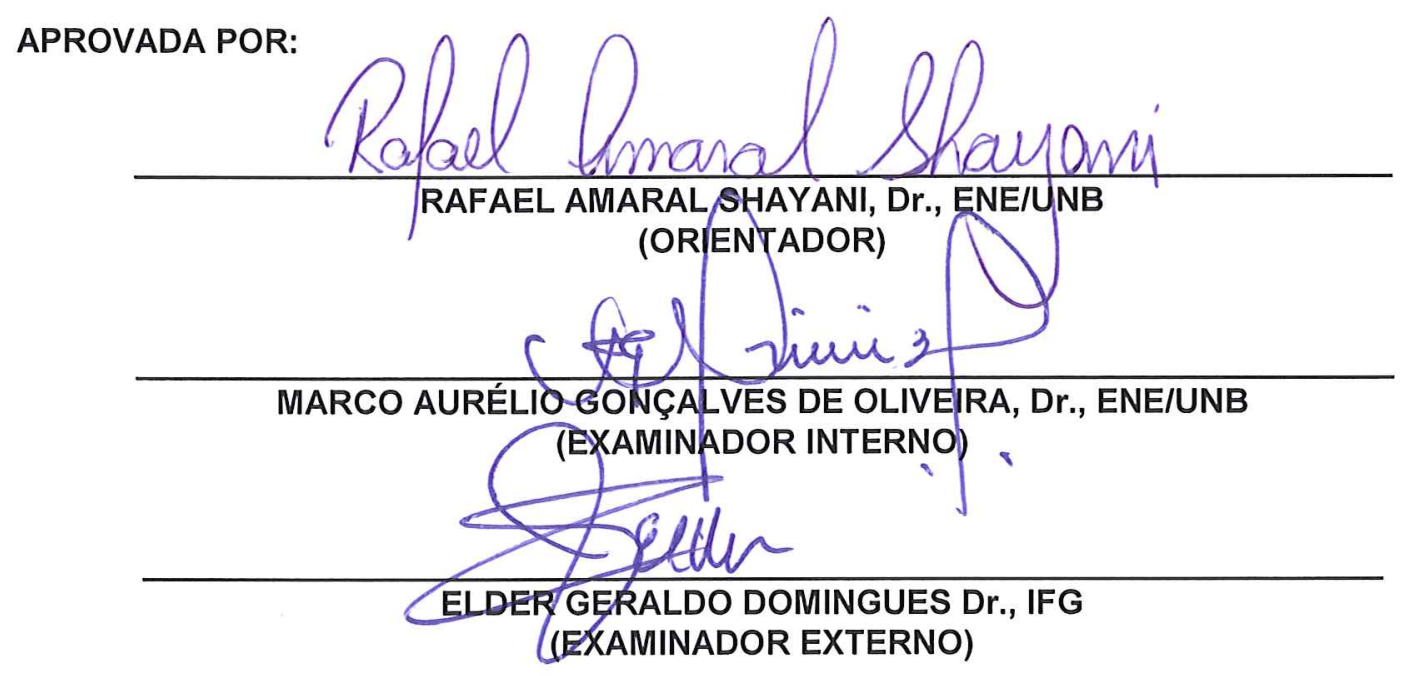

Brasília, 08 de maio de 2015. 


\title{
FICHA CATALOGRÁFICA
}

\author{
MIAN, HELENA MAGALHÃES
}

Análise regulatória da participação da energia solar fotovoltaica e estudo do melhor mecanismo de suporte para inseri-la na matriz elétrica brasileira.

xvi, 108p., 210 x 297 mm (ENE/FT/UnB, Mestre, Engenharia Elétrica, 2015).

Dissertação de Mestrado - Universidade de Brasília. Faculdade de Tecnologia.

Departamento de Engenharia Elétrica.

1. Introdução

3. Mecanismos de suporte e metodologia de comparação

5. Conclusões e sugestões

I. ENE/FT/UnB
2. Revisão bibliográfica

4. Resultados e análises

\section{REFERÊNCIA BIBLIOGRÁFICA}

MIAN, H. M. (2015). Análise regulatória da participação da energia solar fotovoltaica e estudo do melhor mecanismo de suporte para inseri-la na matriz elétrica brasileira. Dissertação de Mestrado em Engenharia Elétrica, Departamento de Engenharia Elétrica, Universidade de Brasília, Brasília, DF, 108p.

\section{CESSÃO DE DIREITOS}

AUTOR: Helena Magalhães Mian

TÍTULO: Análise regulatória da participação da energia solar fotovoltaica e estudo do melhor mecanismo de suporte para inseri-la na matriz elétrica brasileira.

GRAU: Mestre

ANO: 2015

É concedida à Universidade de Brasília permissão para reproduzir cópias desta dissertação de mestrado e para emprestar ou vender tais cópias somente para propósitos acadêmicos e científicos. $\mathrm{O}$ autor reserva outros direitos de publicação e nenhuma parte dessa dissertação de mestrado pode ser reproduzida sem autorização por escrito do autor.

Helena Magalhães Mian

SHIN CA B Bloco A, apto 310-B

CEP: 71503-502. Brasília - DF - Brasil. 
Dedico esse trabalho à Sandy, minha melhor amiga e companheira, cujo amor incondicional nunca esquecerei. 


\section{AGRADECIMENTOS}

Agradeço aos meus pais, Hyldegardes e Teocle, pelo apoio incondicional e por seus esforços para que eu e meus irmãos pudéssemos chegar aonde desejássemos. O amor e dedicação de vocês são a razão de todas as minhas conquistas.

Aos meus irmãos, Paulo e Lygia, pela compreensão e apoio constantes.

A Vânia pela torcida por meu sucesso, não só na realização desse trabalho.

Agradeço ao Tiago pelo companheirismo e ajuda, não só na realização deste trabalho, mas também em todos esses anos de parceria.

Agradeço ao amigo Murilo pela relevante ajuda na realização do trabalho.

Agradeço ao meu orientador Rafael Amaral Shayani e o professor Marco Aurélio Gonçalves de Oliveira pelo esforço em me orientar, me proporcionando ideias, sugestões e conhecimentos. Em especial ao professor Shayani pela atenção e paciência para tirar dúvidas e revisar o trabalho, apontando melhorias em todos os aspectos do texto.

Por fim, agradeço ao Ministério de Minas e Energia por ter me encorajado e possibilitado que cursasse a pós-graduação. Em especial à Juliette Queiroz Monsã, a Mayara Cardoso e ao Doutor Jarbas Raimundo de Aldano Matos. 


\section{RESUMO}

\section{ANÁlise REgUlatória DA PARTICIPAÇÃo DA ENERGIA SOLAR FOTOVOLTAICA E ESTUDO DO MELHOR MECANISMO DE SUPORTE PARA INSERI-LA NA MATRIZ ELÉTRICA BRASILEIRA}

A escolha da fonte de geração de energia elétrica depende de muitos fatores e características particulares de cada país ou região do mundo. A fonte solar fotovoltaica de energia, por ser renovável e abundante, vem sendo adotada em diversos países com diferentes formatos e importância em suas matrizes energéticas e elétricas. Ela pode ocorrer de forma centralizada ou distribuída, essa última, podendo ser isolada ou conectada a rede elétrica. Este estudo busca identificar os instrumentos normativos que deram sustentação ao desenvolvimento da energia fotovoltaica no mundo e propor o mecanismo de suporte mais adequado ao Brasil. No país, duas formas distintas de geração solar fotovoltaica surgiram nos últimos anos: a geração distribuída, através da Resolução Normativa ANEEL nº 482/2012, e a geração centralizada, por meios dos leilões de energia exclusivos para a fonte solar. A regulamentação da geração distribuída é, ainda, uma dificuldade a ser enfrentada, já que no modelo escolhido de compensação de energia, a viabilidade dos empreendimentos depende de vários fatores ainda a ser aprimorados. $\mathrm{O}$ presente trabalho analisa os incentivos e regulamentações já implantados nos países com maior participação de energia fotovoltaica do mundo e sugere mudanças para a consolidação da regulamentação nacional da geração distribuída fotovoltaica conectada à rede de distribuição de energia elétrica. Em um segundo momento, o trabalho compara os dois mecanismos de incentivo a fonte solar fotovoltaica vigente no Brasil, o leilão específico para a fonte, com valores do preço da energia superiores aos praticados em outras formas de geração, e um subsídio sugerido em financiamento a juros baixos para a geração distribuída. Identificou-se que o modelo de leilão tem menos custos para a sociedade brasileira, quando comparado à geração distribuída sem um financiamento específico, com taxas atrativas ao investidor. Em um cenário de taxa de juros de $5 \%$ a.a., a GD já se torna competitiva e, com taxas superiores, os custos para sociedade seriam ainda menores, no entanto poderiam não ser atrativos ao investidor. 


\section{ABSTRACT \\ REGULATORY ANALYSIS OF THE CONTRIBUTION OF SOLAR PHOTOVOLTAIC ENERGY AND STUDY OF THE BEST SUPPORT MECHANISM TO INSERT IT IN THE BRAZILIAN ELECTRICAL ENERGY MIX}

Choosing the source of electricity generation depends on many factors and specific characteristics of each country or region of the world. Solar photovoltaic energy is renewable and abundant and because of that it has been adopted in different countries in different ways and importance in their energy and electrical grids. It can be inserted in centralized or distributed forms, which can be isolated or connected to the power grid. This study seeks to identify the normative instruments that have supported the development of photovoltaics in the world and suggests the most appropriate support mechanism for Brazil. In the country, two distinct forms of solar photovoltaic generation emerged in recent years: distributed generation by ANEEL Resolution 482/2012, and centralized generation, through energy auctions specific for the solar source. The regulation of distributed generation is still a difficulty to be faced, since in the net-metering model chosen the feasibility of projects depends on several factors yet to be improved. This work analyzes the incentives and regulations already in place in countries with higher share of photovoltaic energy in the world and suggests changes to the consolidation of national regulation of photovoltaic distributed generation connected to the electricity distribution grid. In a second step, this work compares the two mechanisms to encourage current photovoltaic solar source in Brazil: the auction specific to solar, with price peaks above to those practiced in other forms of generation; and a subsidy through financing with low interest rates for distributed generation. It was identified that the auction model has less costs to Brazilian society when compared to the distributed generation without specific funding, with attractive rates to investors. In an interest rate scenario of $5 \%$ per year, DG already becomes competitive and at higher rates, the costs to society would be even lower, however it could not be attractive to investors. 


\section{LISTA DE TABELAS}

Tabela 2.1 Participação de energia renovável na matriz dos países e metas futuras estabelecidas.

Tabela 2.2 Eletricidade gerada por fontes renováveis no mundo 10

Tabela 2.3 Capacidade de geração no Brasil. 18

Tabela 2.4 Países com maior Capacidade Solar Fotovoltaica Total Instalada em 2013 (GW) e Capacidade Total Acumulada. 26

Tabela 2.5 Políticas adotadas nos países estudados. .44

Tabela 2.6 Tipos de geração fotovoltaica no Brasil

Tabela 3.1 Financiamento BNDES para fonte solar. 59

Tabela 3.2 Dados do $6^{\circ}$ leilão de energia de reserva 2014 para fonte solar. .70

Tabela 3.3 Dados do Financiamento BNDES aos vencedores do Leilão Solar. .73

Tabela 3.4 Dados da simulação para GD. .74

Tabela 3.5 Dados da simulação para GD. .76

Tabela 3.6 Dados do custo evitado em transmissão. .77

Tabela 4.1 Custos para sociedade com o leilão específico para fonte solar. .81

Tabela 4.2 Custos para sociedade com a geração distribuída subsidiada. 82 


\section{LISTA DE FIGURAS}

Figura 1.1 Principais preocupações na escolha das fontes de energia ........................... 1

Figura 2.1 Oferta Total de energia primária mundial por fonte em Mtep. Período 19712011.

Figura 2.2 Geração total de energia elétrica no mundo em TWh, por fonte. Período 1971-2011.

Figura 2.3 Média de crescimento do PIB nas economias mundiais: 2007 a 2012........ 11

Figura 2.4 Projeção do consumo de eletricidade e de o consumo de energia até 2022.12

Figura 2.5 Participação regional na emissão de $\mathrm{CO}_{2}$ em 2011.

Figura 2.6 Oferta interna de energia no Brasil

Figura 2.7 Matriz de energia elétrica gerada no Brasil em 2013.

Figura 2.8 Variação anual da participação da hidroeletricidade na geração de energia elétrica total no Brasil de 2003 a 2012.

Figura 2.9 Potencial hidrelétrico brasileiro.

Figura 2.10 Participação de renováveis na matriz elétrica.

Figura 2.11 Evolução da geração eólica no Brasil.

Figura 2.12 Geração Centralizada (GC) e Geração Distribuída (GD). .23

Figura 2.13 Evolução da Capacidade Solar Fotovoltaica Total Instalada de 1992 a 2013 (MWp). 26 
Figura 2.14 Evolução da capacidade instalada de energia FV conectada a rede na Alemanha 28

Figura 2.15 Matriz Elétrica Alemã em 2014 28

Figura 2.16 Evolução do custo das instalações (€/Wp) e da capacidade total instalada (MWp) na Alemanha 29

Figura 2.17 Evolução da tarifa prêmio e da capacidade solar fotovoltaica instalada na Alemanha.

Figura 2.18 Tarifa prêmio X Preço da eletricidade em aplicações residenciais na Alemanha.

Figura 2.19 Matriz Elétrica Chinesa em 2012. 33

Figura 2.20 Contribuição Solar Fotovoltaica na geração de eletricidade na EU em 2013.

Figura 2.21 Projeção de geração de energia elétrica por fontes renováveis nos estados Unidos até 2040.

Figura 2.22 Acréscimo anual de energia solar fotovoltaica nos EUA entre 2006 e 2013.

Figura 2.23 Evolução da capacidade solar fotovoltaica instalada na Espanha.

Figura 2.24 Evolução da Tarifa Prêmio para energia fotovoltaica.

Figura 2.25 Capacidade Global de Energia Solar por Concentração

Figura 2.26 Oferta contratada no Brasil, período 2005 a 2013.

Figura 2.27 Estágio do Mineirão em Minas Gerais com sistema solar. 
Figura 2.28 Evolução de capacidade instalada e energia gerada a partir da GDFV.......52

Figura 3.1 Participação dos diferentes sistemas de incentivo a energia FV no mundo....

Figura 3.2 Número de Países com políticas para energia renovável, por tipo. 62

Figura 3.3 Composição tarifária média do Brasil. 67

Figura 3.4 Custo para sociedade do leilão específico para a fonte solar. .74

Figura 3.5 Custo para sociedade da GD subsidiada. .78

Figura 4.1 Análise de sensibilidade do custo para a sociedade do financiamento da GDFV 83

Figura 4.2 Prazos das Distribuidoras nas etapas de acesso de Microgeradores ao Sistema de Distribuição. .86 


\section{LISTA DE SÍMBOLOS, NOMENCLATURAS E ABREVIAÇÕES}

\begin{tabular}{|c|c|}
\hline $\mathrm{ABNT}$ & Associação Brasileira de Normas Técnicas \\
\hline ACL & Ambiente de Contratação Livre \\
\hline ACR & Ambiente de Contratação Regulada \\
\hline ANEEL & Agência Nacional de Energia Elétrica \\
\hline BEN & Balanço Energético Nacional \\
\hline BIG & Banco de Informações da Geração (ANEEL) \\
\hline BMBF & Ministério Alemão da Educação e da Pesquisa \\
\hline BMU & Ministério Alemão do Meio Ambiente \\
\hline BNDES & Banco Nacional de Desenvolvimento Econômico e Social \\
\hline $\mathrm{BOE}$ & Boletín Oficial del Estado (Espanha) \\
\hline $\mathrm{BP}$ & British Petroleum \\
\hline CCEE & Câmara de Comercialização de Energia Elétrica \\
\hline $\mathrm{CDE}$ & Conta de Desenvolvimento Energético \\
\hline CEF & Caixa Econômica Federal \\
\hline cEUR & Centavos de Euros \\
\hline $\mathrm{CF}$ & Constituição Federal \\
\hline CIP & Contribuição para o custeio do serviço de Iluminação Pública \\
\hline $\mathrm{CNY}$ & Moeda chinesa (yuan) \\
\hline $\mathrm{CNY} / \mathrm{kWh}$ & Yuan por Quilowatt hora \\
\hline COFINS & Contribuição para o Financiamento da Seguridade Social \\
\hline CONFAZ & Conselho Nacional de Política Fazendária \\
\hline CSI & California Solar Initiative \\
\hline CSP & Concentrating Solar Power - Energia Solar Concentrada \\
\hline CUSD & Contrato de Uso do Sistema de Distribuição \\
\hline$€$ & Euro \\
\hline EEG & Erneuerbare-Energien-Gesetz - Código das Fontes Renováveis de Energia \\
\hline Eletrobrás & Centrais Elétricas Brasileiras S/A \\
\hline EIA & U.S. Energy Information Administration \\
\hline EPE & Empresa de Pesquisa Energética \\
\hline EPIA & European Photovoltaic Industry Association \\
\hline EUA & Estados Unidos da América \\
\hline
\end{tabular}


Fraunhofer ISE Institute for Solar Energy Systems ISE

FIES Fundo de Incentivo à Energia Solar

FINEM linha de Financiamento de empreendimentos do BNDES

FiT $\quad$ Feed-in-Tariff - Tarifa Prêmio

FV Fotovoltaica

GD Geração distribuída

GDFV Geração Distribuída Fotovoltaica

GW Gigawatts

ICMS Imposto sobre Circulação de Mercadorias e Serviços

IEA International Energy Agency

IEA - PVPS International Energy Agency - Photovoltaic Power Systems Programme

ISES International Solar Energy Society

JPY Moeda Japonsa (Iene)

$\mathrm{kW} \quad$ Quilowatts

kWh Quilowatts-hora

LER Leilão de Reserva de Energia

LFA Leilão de Fontes Alternativas de Energia

MDIC Ministério do Desenvolvimento, Indústria e Comércio Exterior

MME Ministério de Minas e Energia

MP Medida Provisória

Mtep Mega tonelada equivalente de petróleo

MW Mega watts

MWp Megawatts pico

OIE Oferta Interna de Energia

ONS Operador Nacional do Sistema

PASEP Programa de Formação do Patrimônio do Servidor Público

PCH Pequena Central Hidroelétrica

PDE Plano Decenal de Expansão de Energia

P\&D Pesquisa e Desenvolvimento

PIB Produto Interno Bruto

PIS Programa de Integração Social

PL Projeto de lei

PNMC Programa Nacional sobre Mudança do Clima

PRODIST Procedimentos de Distribuição 
PROINFA Programa de Incentivo às Fontes Alternativas de Energia Elétrica

PV Photovoltaic - Fotovoltaica

RD Real Decreto

REN21 Renewable Energy Policy Network for the 21st Century

RGR Reserva Global de Reversão

RN Resolução Normativa

RPS Renewable Portfolio Standard

RSU Resíduos Sólidos Urbanos

SFCR Sistema Fotovoltaico Conectado à Rede

SIN Sistema Elétrico Interligado Nacional

Tep Tonelada equivalente de petróleo

TUSD Tarifa sobre o Uso do Sistema de Distribuição

TUST Tarifa sobre o Uso do Sistema de Transmissão

TWh Terawatt hora

UC Unidade Consumidora

UFV Usina Solar Fotovoltaica

UHE Usina hidrelétrica

US\$ Dólares americanos

US\$/W Dólares por Watt

VR Valor Anual de Referência

W Watt

$\mathrm{Wh} / \mathrm{m}^{2}$.dia Watt hora por metro quadrado dia 


\section{SUMÁRIO}

1. INTRODUÇÃ $O$............................................................................................................... 1

1.1. TRABALHOS ANTERIORES RELACIONADOS AO TEMA ...................... 2

1.2. OBJETIVO DO TRABALHO ..................................................................... 3

1.3. ESTRUTURAÇÃO DO TRABALHO .................................................................. 4

2. REVISÃO BIBLIOGRÁFICA ..................................................................................... 6

2.1. CENÁRIO ENERGÉTICO MUNDIAL ................................................................ 6

2.1.1. Consumo de energia ............................................................................................6 6

2.1.2. Consumo de eletricidade .........................................................................8

2.2. CENÁRIO ENERGÉTICO BRASILEIRO ........................................................ 10

2.2.1. Geração hidrelétrica................................................................................... 14

2.2.2. Complementação térmica .......................................................................17

2.2.3. O desenvolvimento da geração éólica no Brasil........................................... 18

2.3. NOVOS DESAFIOS PARA O SETOR ELÉTRICO BRASILEIRO ............. 19

2.4. POTENCIAL DA ENERGIA SOLAR ............................................................ 21

2.4.1. Geração centralizada......................................................................................... 22

2.4.2. Geração distribuída.....................................................................................23

2.5. INSERÇÃO DA GERAÇÃO FOTOVOLTAICA NA MATRIZ MUNDIAL .. 24

2.5.1. Países com maior produção de energia solar fotovoltaica ............................ 25

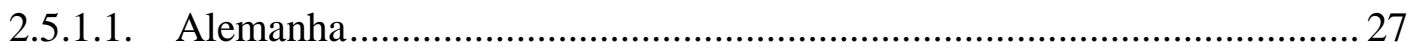

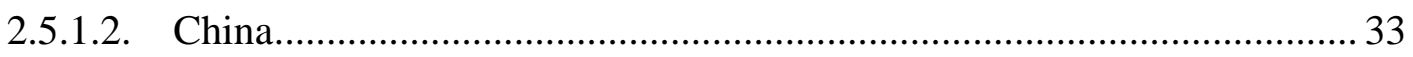

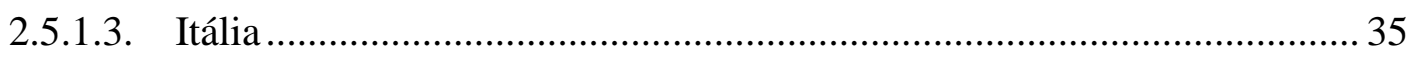

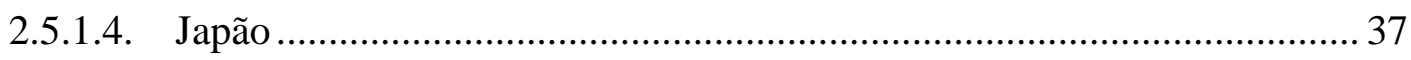

2.5.1.5. Estados Unidos da América............................................................... 38

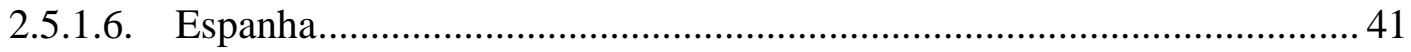

2.5.2. Resumo dos mecanismos utilizados nos países abordados ......................... 43

2.6. LEGISLAÇÃO BRASILEIRA PARA ENERGIA SOLAR .......................... 44

2.6.1. Modelo do setor elétrico e a fonte solar ........................................................ 44

2.6.1.1. Resolução Normativa ANEEL $n^{\circ}$ 482/2012.............................................. 49

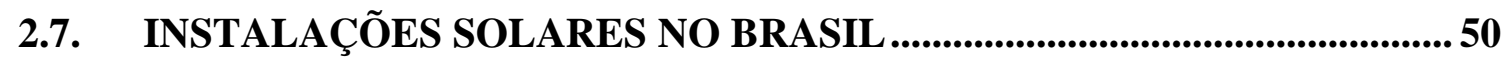


3. MECANISMOS DE SUPORTE E METODOLOGIA DE COMPARAÇÃO .....54

3.1. MECANISMOS DE SUPORTE................................................................5 54

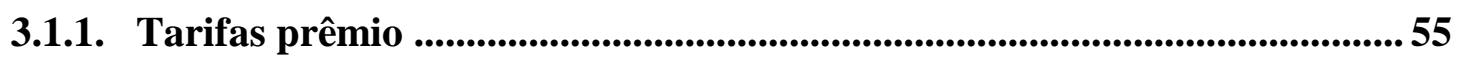

3.1.2. Cotas de energia........................................................................................56

3.1.3. Desconto em impostos e incentivos de investimentos ................................5 57

3.1.4. Compensação de energia elétrica ............................................................60

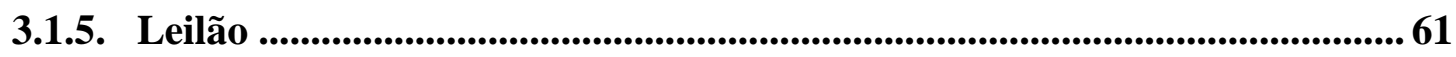

3.1.6. A evolução dos incentivos ......................................................................61

3.2. CENÁRIO IDEAL DA REGULAMENTAÇÃO DA GD .............................. 63

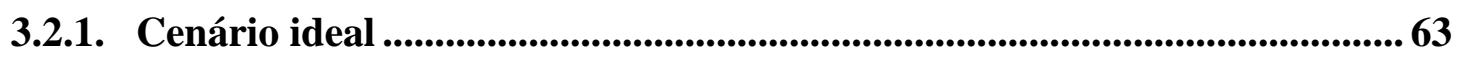

3.2.1.1. Sob a ótica da concessionária de distribuição ......................................6 63

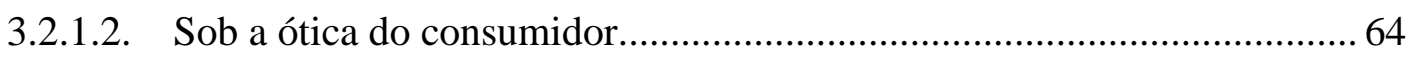

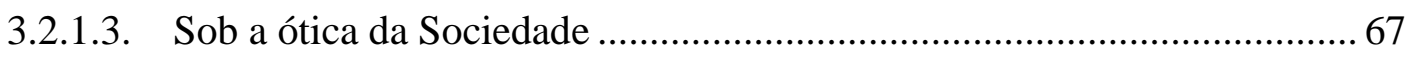

3.3. METODOLOGIA DE COMPARAÇÃO ENTRE OS INCENTIVOS

ATUAIS NO BRASIL ...................................................................................................69

3.3.1. Leilão específico para fonte solar ..............................................................70

3.3.2. Geração distribuída.......................................................................... 74

3.3.3. Cálculo do Valor Presente ................................................................................... 78

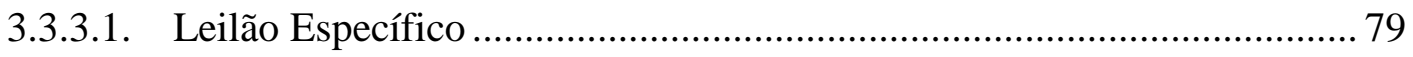

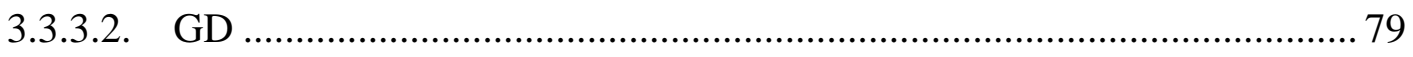

3.3.3.3. Custo evitado de Transmissão ................................................................. 79

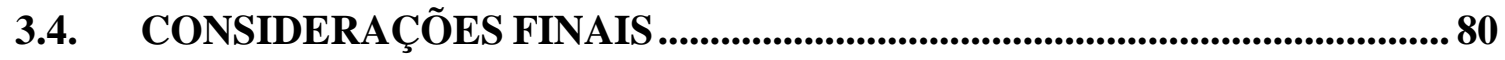

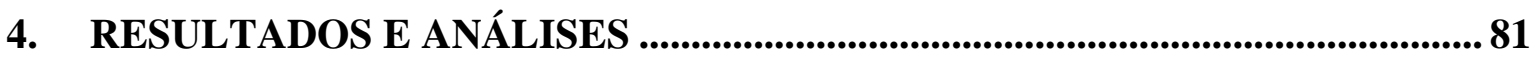

4.1. INCENTIVO MAIS APROPRIADO PARA O BRASIL ............................8 81

4.2. MUDANÇAS NO CENÁRIO REGULATÓRIO BRASILEIRO PARA

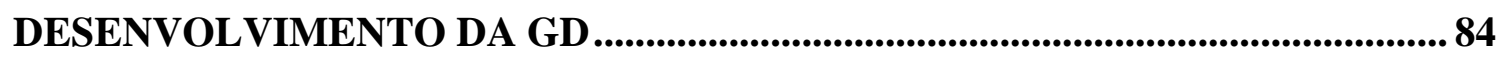

4.2.1. PRODIST e normas das distribuidoras......................................................... 85

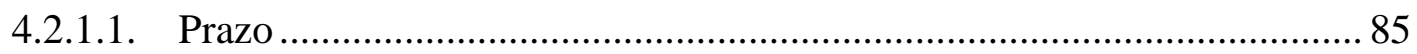

4.2.1.2. Responsabilidades do acessante e da distribuidora .............................. 87 
4.2.1.3. Critérios para seleção de projetos de GD 88

4.2.2. Metodologia para inserção da GD ................................................................ 89

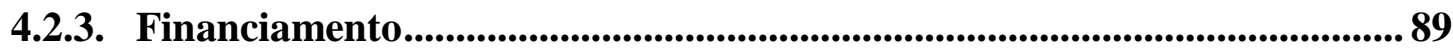

4.2.4. Questões tributárias ..............................................................................90

4.3. CONSIDERAÇÕES FINAIS............................................................................. 91

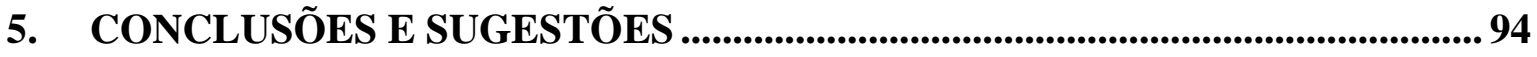

5.1. CONCLUSÕES DO TRABALHO ........................................................... 94

5.2. RECOMENDAÇÕES PARA PESQUISAS FUTURAS ..................................96

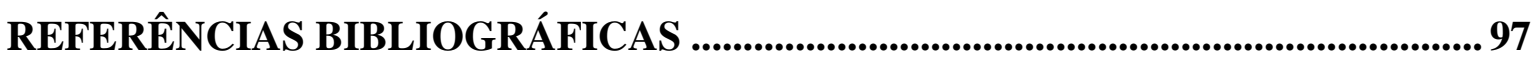

APÊNDICE A - RESULTADO DO $6^{\circ}$ LEILÃO DE ENERGIA DE RESERVA..... 106

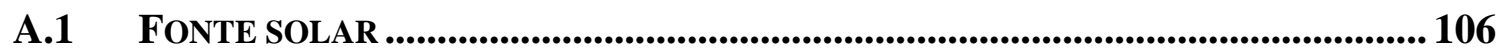

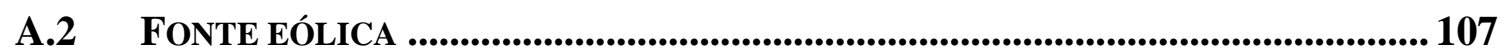




\section{INTRODUÇÃO}

O desenvolvimento da sociedade vem, historicamente, acompanhado de um aumento em seu consumo de energia. Essa dependência tem se intensificado com o crescimento da população mundial, aliado à elevação nos padrões de qualidade de vida e, consequentemente, ao aumento da demanda por energia. Esse cenário é ainda mais evidente nos países em desenvolvimento, uma vez que a demanda por energia se coloca como pilar para o crescimento, seja pela via do desenvolvimento industrial, seja pelo incentivo ao consumo e pela distribuição de renda (ABREU et al., 2010a).

As diversas formas de transformação dos recursos naturais em energia para o desenvolvimento da sociedade traz questões multidisciplinares que se mostram cada vez mais indispensáveis. Entre as principais preocupações na escolha das fontes de energia estão: os impactos ao meio ambiente, a preocupação com a possibilidade de esgotamento dos recursos naturais e os custos de exploração destes recursos (Figura 1.1). A composição do aproveitamento dos recursos energéticos não é somente um elemento estratégico para a economia de um país, mas também um elemento de bem estar para a sociedade, hoje e do futuro.

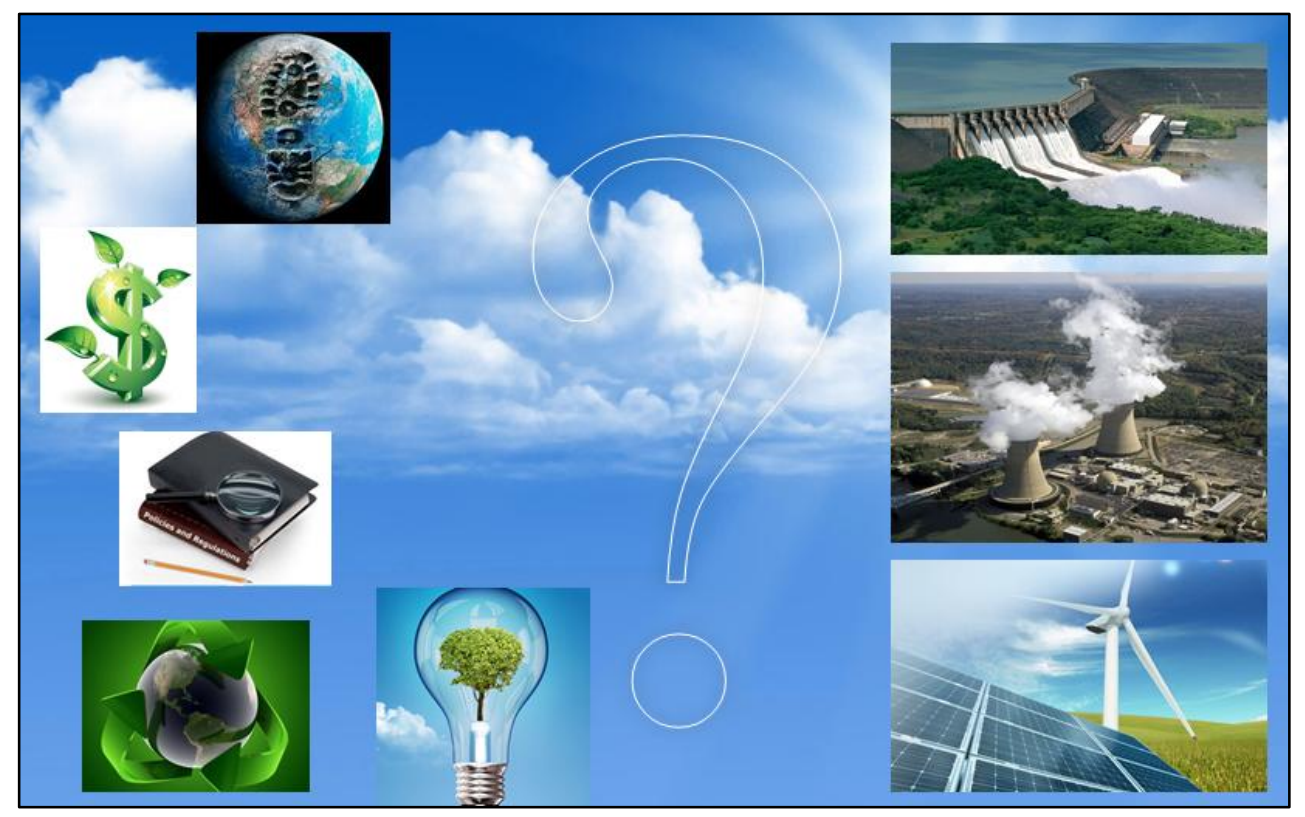

Figura 1.1 Principais preocupações na escolha das fontes de energia 
O Brasil, que tem historicamente utilizado predominantemente a geração hidrelétrica, e a termoeletricidade de forma complementar, para suprir sua demanda por energia elétrica, vem recentemente investindo em formas de energia renováveis consideradas por muitos como alternativas: a eólica e a solar. A energia eólica, já faz alguns anos, tem destaque no portfolio dos leilões de energia e a solar começou a aparecer no país graças às novas regulamentações, possibilitando a geração distribuída, e a participação recente em leilões do setor.

Dentro dessa necessidade de estudar e incentivar o uso da energia solar no País, A Agência Nacional de Energia Elétrica (ANEEL) realizou a Chamada Pública de Projeto de Pesquisa e Desenvolvimento Estratégico 013/2011 - “Arranjos Técnicos e Comerciais para Inserção da Geração Solar Fotovoltaica na Matriz Energética Brasileira”, a fim de disseminar o conhecimento da geração fotovoltaica conectada à rede no Brasil, desenvolver a cadeia produtiva da energia solar e promover a capacitação de empresas e profissionais. Essa iniciativa recebeu 18 propostas, envolvendo 96 empresas, 62 instituições de ensino e pesquisa e quase 600 pesquisadores. Esse trabalho tem como uma de suas motivações a participação da Universidade de Brasília em um desses projetos, o Jaíba Solar. O empreendimento consiste na instalação de uma usina fotovoltaica (UFV) com potência de 3 MWp com diversas tecnologias, logo, estudos sobre arranjos comerciais, no caso, via leilão de energia, são necessários.

\subsection{TRABALHOS ANTERIORES RELACIONADOS AO TEMA}

Alguns trabalhos foram realizados para averiguar o desenvolvimento da energia solar fotovoltaica tanto de forma distribuída quanto por meio de leilões específicos.

No artigo "Economic performance and policies for grid-connected residential solar photovoltaic systems in Brazil" (MITSCHER \& RUTHER, 2012), os autores analisam a competitividade econômica da geração fotovoltaica distribuída de pequeno porte em algumas capitais brasileiras e concluem que o custo de capital no Brasil é parâmetro decisivo para a competitividade da energia $\mathrm{FV}$ e que financiamentos de longo prazo e baixo custo são essenciais para que a tecnologia se torne economicamente atrativa. A análise mostra que, com taxas de juros subsidiadas, a energia FV ficaria economicamente competitiva em vários locais do país, devido às altas tarifas de energia e dos altos níveis de 
irradiação, no entanto, em um cenário sem financiamentos a juros reduzidos, a alternativa fotovoltaica é inviável.

No artigo "Grid-connected photovoltaic in Brazil: Policies and potencial impacts for 2030" (JANNUZZI \& MELO, 2013), os autores estudam três formas de política de incentivo no mercado de energia solar FV distribuída no Brasil: o sistema de compensação (net-metering), tarifas prêmio e incentivos financeiros, isto é, isenção de impostos. Os autores concluem que o sistema em vigência, compensação de energia, é o melhor em regiões onde a paridade com a tarifa já foi atingida, ou seja, regiões onde se combinam altos níveis de irradiação e altas tarifas de eletricidade. Nas demais áreas, onde ainda não há paridade, principalmente nas regiões sul e norte do país, outros incentivos são necessários para a difusão da tecnologia. Nesse caso, os incentivos financeiros se mostram como opção mais apropriada do que as tarifas prêmio, por terem um custo menor para a sociedade como um todo.

No artigo "Assessing incentive policies for integrating centralized solar power generation in the Brazilian electric power system" (MALAGUETA et al.,2013), os autores analisam os impactos de promover, por meio de leilões, a geração solar fotovoltaica de forma centralizada no Brasil e demostram que leilões específicos devem ser adotados, assim como políticas complementares para promover investimentos em P\&D. O estudo comprova que, sem a realização de leilões específicos, como os realizados no passado para a energia eólica, biomassa e pequenas centrais hidrelétricas, não há, por falta de viabilidade econômica, previsão de plantas solar fotovoltaicas até 2040 .

\subsection{OBJETIVO DO TRABALHO}

O objetivo geral do presente trabalho é analisar o crescimento da utilização da fonte solar fotovoltaica de energia no Brasil e no mundo, apontando pontos de melhoria, com base na experiência internacional, para uma futura consolidação da regulamentação nacional e analisar formas de inseri-la na matriz elétrica brasileira, do ponto de vista da regulamentação do setor.

Como objetivo específico, procura-se identificar qual incentivo é economicamente e politicamente mais interessante ao país a fim de estimular o desenvolvimento da fonte 
solar fotovoltaica na matriz elétrica brasileira. Pretende-se também identificar os gargalos existentes na regulamentação nacional e propor formas mais eficientes de incentivos específicos para a realidade brasileira. Para isso, compara-se o subsídio utilizado ao realizar o leilão para fonte fotovoltaica, realizado em outubro de 2014, com os custos de redução de juros de implantação da geração distribuída, que ainda não possui uma linha de crédito para os consumidores residenciais que aderirem ao sistema de compensação criado pela RN ANEEL $\mathrm{n}^{\circ} 482 / 2012$, com vantagens similares aos financiamentos existentes aos grandes empreendimentos de energia do Brasil.

\subsection{ESTRUTURAÇÃO DO TRABALHO}

Esta dissertação é estruturada em cinco capítulos. Este capítulo faz a introdução do trabalho, mostrando a motivação para escolha do tema, os objetivos desse estudo e explica como o trabalho foi estruturado.

O segundo capítulo traz a revisão bibliográfica, apresenta-se primeiramente o cenário energético mundial e brasileiro, com maior enfoque para a energia elétrica, quando são apresentados os desafios para o setor elétrico brasileiro. Este capítulo aborda também o potencial da energia solar e as formas usadas em alguns países para desenvolvê-la, demonstrando as opções técnicas adotadas e os incentivos necessários à implantação da energia solar fotovoltaica. Por fim, é discutido o estado da arte da legislação brasileira para a energia solar e a atual situação do país nesse tema.

No capítulo 3, é realizada uma análise mais detalhada dos mecanismos de suporte adotados em diversos outros países para desenvolver a energia fotovoltaica, tanto de forma distribuída quanto centralizada. Em seguida, busca-se chegar a um cenário ideal da regulamentação de forma a possibilitar o desenvolvimento da geração distribuída no Brasil. Finalmente, é escolhida uma metodologia para comparar os possíveis incentivos existentes no país para inserção da energia solar fotovoltaica.

O capítulo 4 descreve os resultados obtidos com a execução da metodologia proposta e apresenta as análises para determinação do melhor caminho regulatório para incentivar a energia solar no Brasil. 
Finalmente, no capítulo 5 são apresentadas as conclusões do presente trabalho e são sugeridas pesquisas futuras em relação ao tema. 


\section{REVISÃO BIBLIOGRÁFICA}

Este capítulo traz uma breve revisão bibliográfica sobre os temas relevantes para o estudo regulatório da energia solar fotovoltaica. São apresentadas as formas como a energia solar fotovoltaica pode ser explorada pelos países. Por fim, são apresentados os mecanismos regulatórios utilizados no mundo para estimular essa tecnologia e os principais países que inseriram de forma significativa esse tipo de tecnologia em suas matrizes elétricas.

\subsection{CENÁRIO ENERGÉTICO MUNDIAL}

O progresso da civilização humana é historicamente relacionado ao acesso da sociedade à energia. Necessária em todas as atividades desenvolvidas pelo homem, tanto na sua forma mais primitiva, como a alimentação, a força para realizar um trabalho e o aquecimento; quanto ao desenvolvimento tecnológico, na indústria, na medicina, na comunicação e em vários outros setores da economia.

\subsubsection{Consumo de energia}

Atualmente, no mundo, são utilizadas diferentes formas de energia para auxiliar a sociedade em suas diversas áreas. Ela pode ser transformada a partir de um material encontrado na natureza, ou proveniente de fenômenos naturais (vento e luz solar, por exemplo), a fim de se obter outra forma mais apropriada para determinada aplicação. A Figura 2.1 apresenta a evolução da oferta total de energia primária no mundo por fonte, ou seja, são as fontes oriundas da natureza, em sua forma direta. Os valores são representados em Mtep (Mega tonelada equivalente de petróleo). ${ }^{1}$

Nota-se pela Figura 2.1 que a maior parte da energia utilizada no mundo provem de fontes não renováveis e poluentes como carvão, petróleo e gás natural. O aumento da população e a elevação dos padrões de qualidade de vida acarretam um crescimento cada vez maior na demanda de energia. A IEA (IEA, 2010) prevê um aumento global da demanda de energia em uma taxa de $1,5 \%$ ao ano de 2010 a 2030, levando a um aumento do consumo de petróleo em $22 \%$, do gás natural em $42 \%$ e do carvão em $53 \%$.

\footnotetext{
${ }^{1}$ Uma tep corresponde à energia que se pode obter a partir de uma tonelada de petróleo padrão.
} 


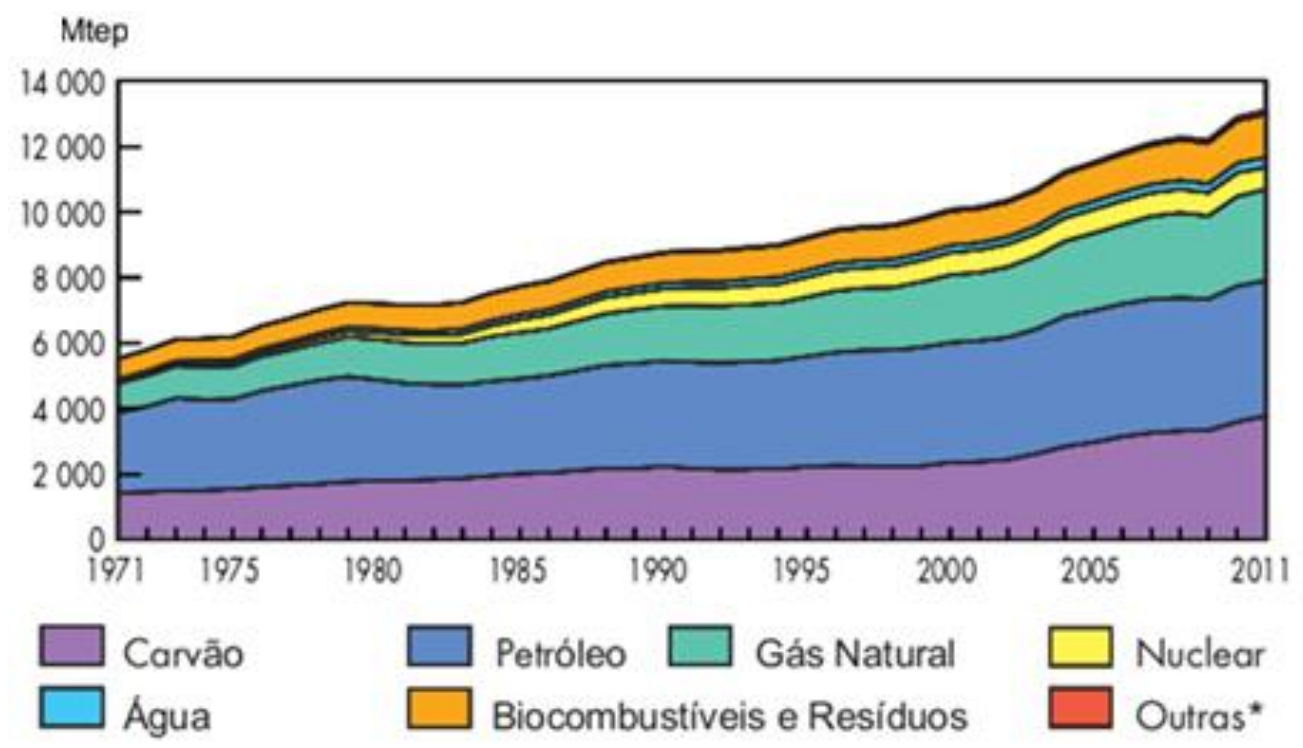

*Outras inclui solar, eólica, geotérmica, etc.

Fonte: IEA - International Energy Agency. Key World Energy Statistics $2013 b$ (modificado). Disponível em: <www.iea.org>. Acesso em: agosto/2014

Figura 2.1 Oferta Total de energia primária mundial por fonte em Mtep. Período 19712011.

As fontes de geração tradicionais e, portanto, melhores do ponto de vista econômico, são mais poluentes que as renováveis, e causam diversos problemas, como lixo tóxico, poluição e aquecimento global. Os impactos ambientais negativos, de caráter local, regional e mundial, resultantes da produção e do uso da energia representam ameaça ao bem estar da população atual e das gerações futuras. Além disso, as reservas de combustíveis fósseis são escassas e estão diminuindo a ritmos acelerados (BP, 2014). Se não ocorrerem mudanças, um cenário futuro insustentável e poluidor agravará o abastecimento energético mundial. Sendo assim, surge a necessidade de se utilizar outros tipos de tecnologias, com menor impacto ao meio ambiente e de origem renovável.

Na Tabela 2.1, do REN21, nota-se a preocupação dos países europeus em aumentar a participação de fontes renováveis. A Espanha, por exemplo, que em 2012 tinha apenas 14\% de participação de fontes renováveis, já estabelece uma meta para 2020 de 20,8\%. 
Tabela 2.1 Participação de energia renovável na matriz dos países e metas futuras estabelecidas.

\begin{tabular}{|c|c|c|c|}
\hline \multicolumn{4}{|c|}{ Participação de energia renovável na matriz energética } \\
\hline \multirow[t]{13}{*}{ Energia Final } & & Atual & Meta \\
\hline & China & $9,2 \%(2013)$ & 9,5 até 2015 \\
\hline & França & $7,9 \%(2011)$ & $23 \%(2020)$ \\
\hline & Alemanha & $12 \%(2013)$ & $18 \%(2020)$ \\
\hline & & & $30 \%(2030)$ \\
\hline & & & $45 \%(2040)$ \\
\hline & & & $60 \%(2050)$ \\
\hline & Portugal & $25 \%(2012)$ & $31 \%(2020)$ \\
\hline & Espanha & $14 \%(2012)$ & $20,8 \%(2020)$ \\
\hline & Suíça & $48 \%(2011)$ & $50 \%(2020)$ \\
\hline & Reino Unido & - & $15 \%(2020)$ \\
\hline & Brasil & $42 \%(2012)$ & - \\
\hline & Itália & - & $17 \%(2020)$ \\
\hline Energia Primária & Japão & $7,1 \%(2012)$ & $10 \%(2020)$ \\
\hline
\end{tabular}

Fonte: REN21. Renewables 2014 - Global Satus Report (modificado).

\subsubsection{Consumo de eletricidade}

O setor de energia elétrica é destaque devido à parcela significante no consumo total de energia e também no papel decisivo para permitir padrões adequados de qualidade de vida. A Figura 2.2 mostra que as fontes de energia elétrica que predominam, assim como no caso de energia em geral, são de origem fóssil.

A participação nuclear é bastante expressiva, no entanto sua participação se manteve praticamente constante nas últimas décadas. A energia proveniente da água é a terceira fonte em geração de energia elétrica no mundo e ainda está em crescimento, embora não tão acentuado quanto no passado. Nota-se também que as fontes alternativas, em vermelho, estão se tornando mais expressivas, com crescimento bastante acentuado. 


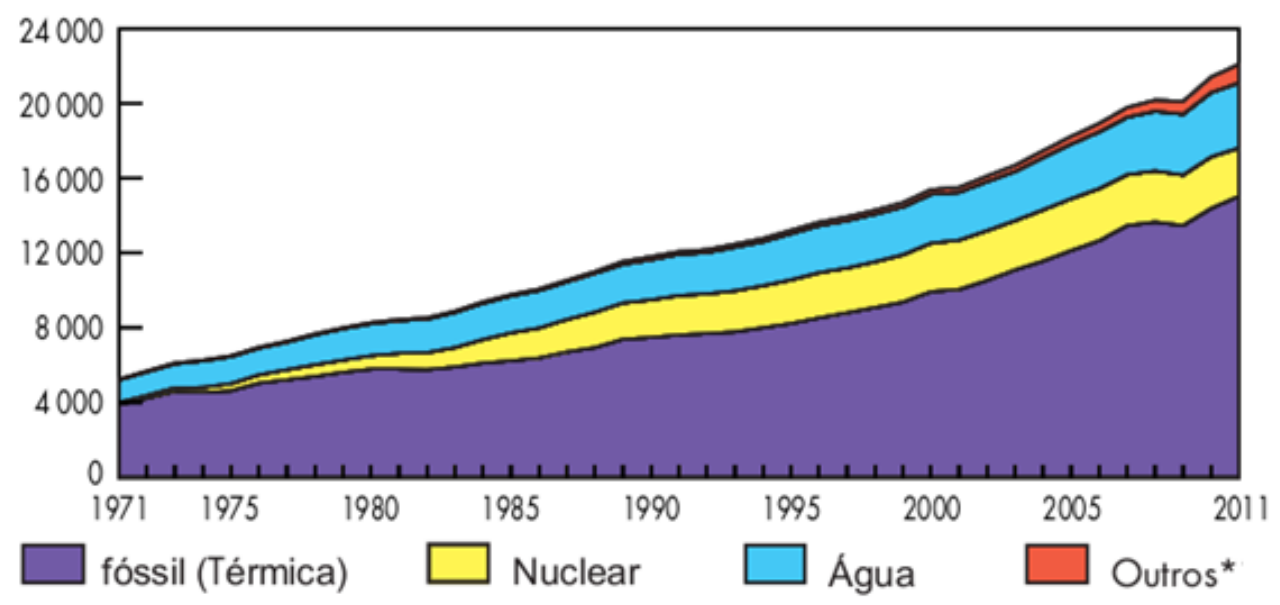

*Outros inclui solar, eólica, geotérmica, etc.

Fonte: IEA - International Energy Agency, 2013b. Key World Energy Statistics (modificado).

Disponível em: <www.iea.org>. Acesso em: agosto/2014.

Figura 2.2 Geração total de energia elétrica no mundo em TWh, por fonte. Período 1971-2011.

Como pode ser observado na Tabela 2.2, o crescimento das fontes consideradas alternativas para geração de energia elétrica é visto em vários países, com diversos mecanismos e esforços para incentivá-las. Todos os países da figura preveem um aumento da participação de fontes de energia renovável em 2035, em relação a 2011, exceto um, o Brasil, o único que prevê reduzir a parcela de energia renovável na geração de energia elétrica, de $87,1 \%$ para $79,5 \%$, embora haja um aumento na participação de fontes como solar e eólica.

Em resumo, percebe-se que o consumo de energia elétrica está crescendo, vários países estão se esforçando para evitar que a matriz se torne ainda mais dependente de recursos fósseis, no entanto o Brasil vai contra a tendência mundial, diminuindo a participação de fontes renováveis em sua matriz. 
Tabela 2.2 Eletricidade gerada por fontes renováveis no mundo.

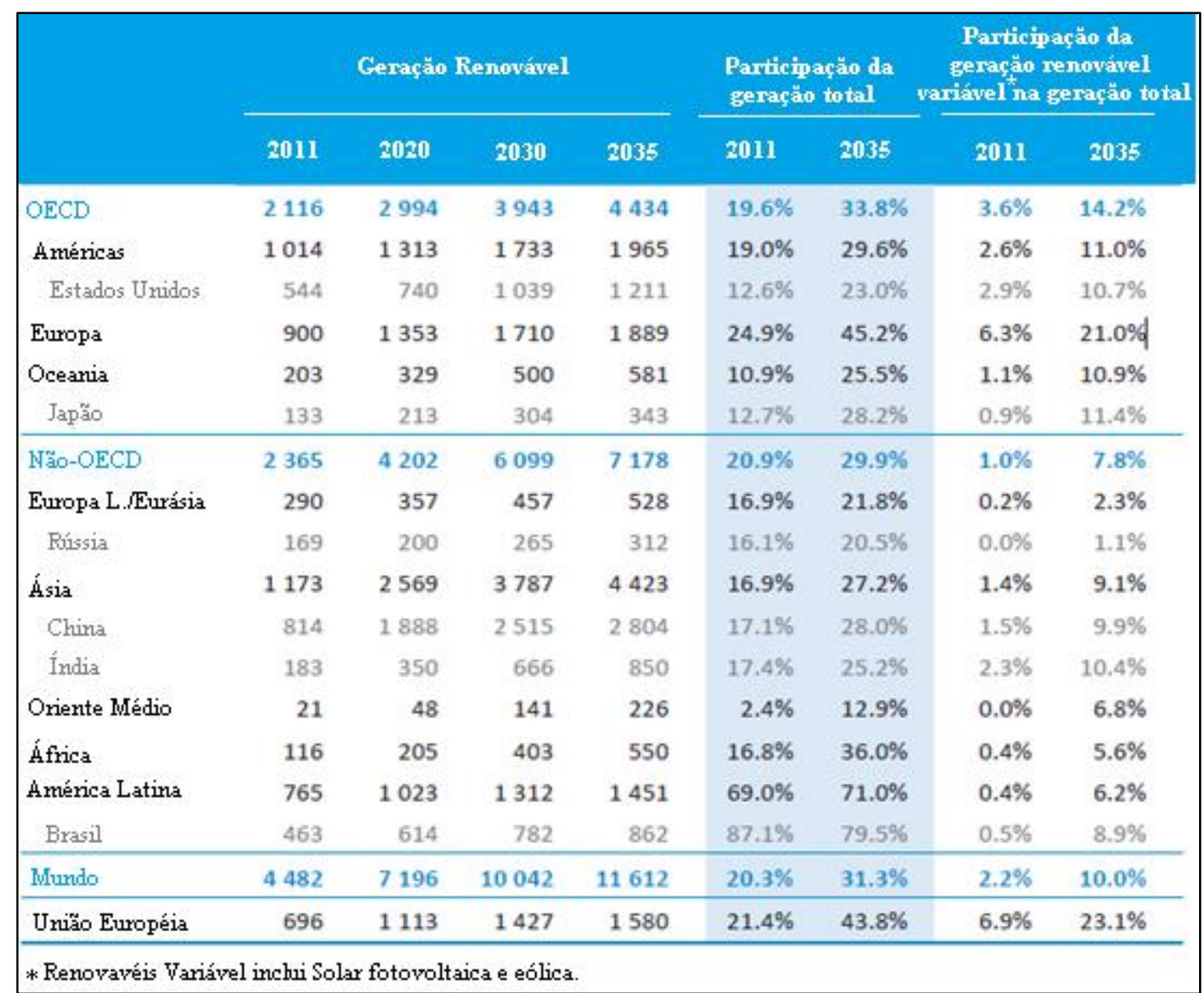

Fonte: IEA - International Energy Agency. World Energy Outlook 2013. (2013a). Disponível em: $<$ http://www.iea.org/>. Acesso em: junho de 2014.

\subsection{CENÁRIO ENERGÉTICO BRASILEIRO}

Esta seção visa situar a questão energética brasileira no que se refere às fontes de energia e, mais especificamente, energia elétrica, empregadas atualmente e historicamente no País. Para isso, são utilizados dados oficiais do governo federal, elaborados através da Empresa de Pesquisa Energética (EPE), do Ministério de Minas e Energia (MME) e da Agência Nacional de Energia Elétrica (ANEEL).

Embora atualmente o Brasil apresente crescimento econômico perto de zero, do ponto de vista do crescimento médio nos últimos anos, o Brasil teve números superiores ao de países mais desenvolvidos, conforme pode ser visto na Figura 2.3. Levando-se em consideração que o crescimento econômico é diretamente relacionado ao acesso à energia, 
espera-se que o consumo energético brasileiro apresente um elevado crescimento nos próximos anos, como pode ser observado na Figura 2.4.

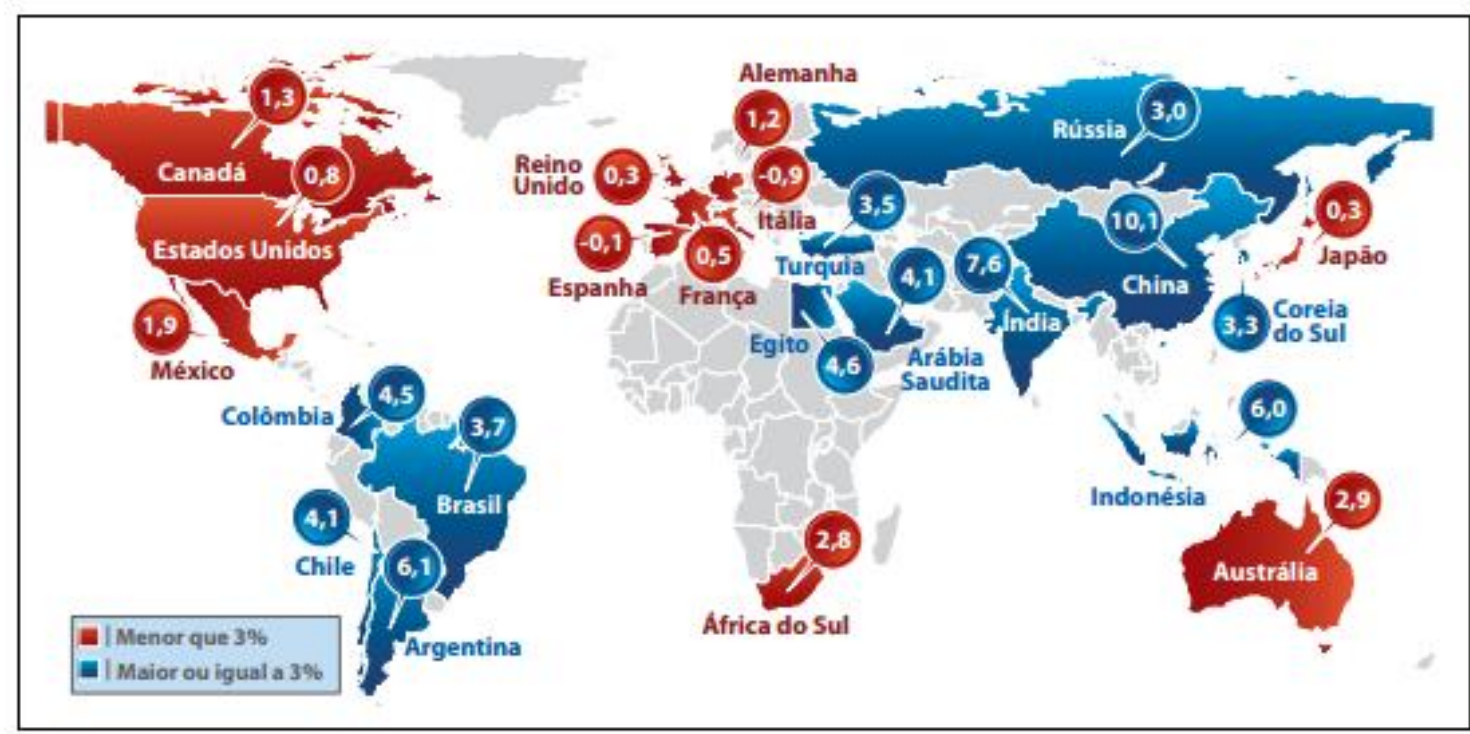

Fonte: SPE - Secretaria de Política Econômica, 2014. Disponível em: <https://www1.fazenda.gov.br/spe/novo_site/home/panorama_economia.html >.

Figura 2.3 Média de crescimento do PIB nas economias mundiais: 2007 a 2012.

É clara a necessidade de uma oferta abundante de energia elétrica que supra os níveis de crescimento econômico estimados pelo governo, além de promover o bem estar social. No Plano Decenal de Expansão de Energia - PDE 2023, trabalha-se considerando uma taxa média de crescimento mundial do PIB de cerca de 3,8\% ao ano, enquanto o PIB do Brasil se expandirá a uma taxa média de 4,3\% ao ano (MME/EPE, 2015).

Embora, tecnicamente, o país esteja atualmente em um momento de recessão, apresentando crescimento próximo à zero, a expectativa do planejador é que haja uma retomada de crescimento da economia brasileira, explicado pela perspectiva de elevação de investimento e produtividade. Assim, é necessário ter energia para garantir o crescimento sem riscos de racionamento, já que sem oferta de energia, o crescimento econômico também é prejudicado. 


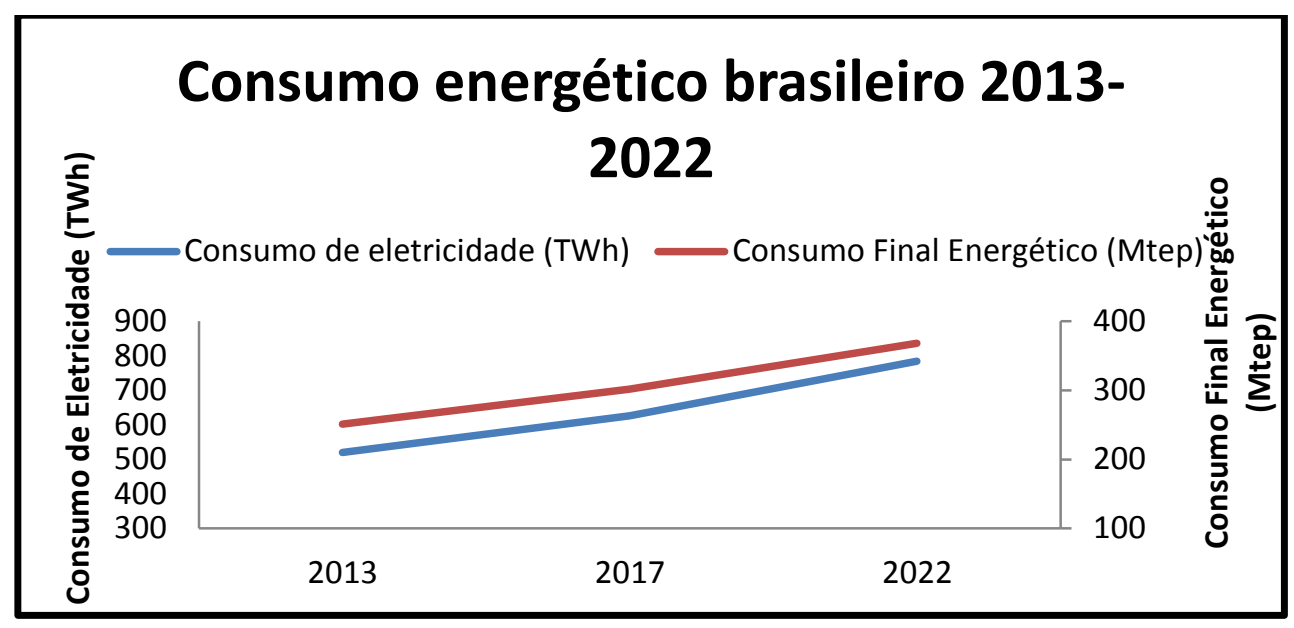

Fonte: Fonte: MME - Ministério de Minas e Energia, EPE - Empresa de Pesquisa Energética. Plano Decenal de Expansão de Energia 2013 - 2022. Brasília, MME/EPE, 2013b. Disponível em <www.mme.gov.br>. Acesso em: julho de 2014.

Figura 2.4 Projeção do consumo de eletricidade e de o consumo de energia até 2022.

No entanto, não basta simplesmente ter acesso à energia, há de se considerar a sustentabilidade e os impactos da produção dessa energia como fatores relevantes no mundo atual (MME/EPE, 2012). Historicamente, o Brasil apresenta uma condição de destaque mundial quanto à utilização de recursos renováveis, principalmente em um mundo que enfrenta um paradoxo: a dependência de combustíveis fósseis conjugada com a preocupação dos impactos globais oriundos das mudanças climáticas e, cada vez mais, comprometido com a preservação dos recursos naturais (PRADO, 2014). O documento Key World Energy Statistics 2013 da Agência Internacional de Energia (IEA) mostra o País como um dos maiores produtores de hidroeletricidade do mundo e um dos menores em emissão total de $\mathrm{CO}_{2}$.

O Brasil, embora necessite de energia para seu crescimento, possui o compromisso de manter as matrizes energética e elétrica com maior participação de fontes renováveis. Assim sendo, o modelo de crescimento deve ser planejado à luz dessas orientações, e não se basear no consumo de combustíveis fósseis como alguns países ainda vêm fazendo, como por exemplo, a China. Ela é o país com maior crescimento mundial, como mostrado na Figura 2.3, e, consequentemente, com a maior demanda por energia. Embora o País venha se destacando por adicionar à sua matriz energética grandes blocos de energia renovável, seu crescimento energético ainda é baseado na queima do carvão. Em 2011, a China foi responsável por mais de $25 \%$ da emissão de $\mathrm{CO}_{2}$ no mundo, como mostra a 
Figura 2.5, que traz as emissões de $\mathrm{CO}_{2}$ oriundas de queima de combustíveis fósseis em cada um dos países.
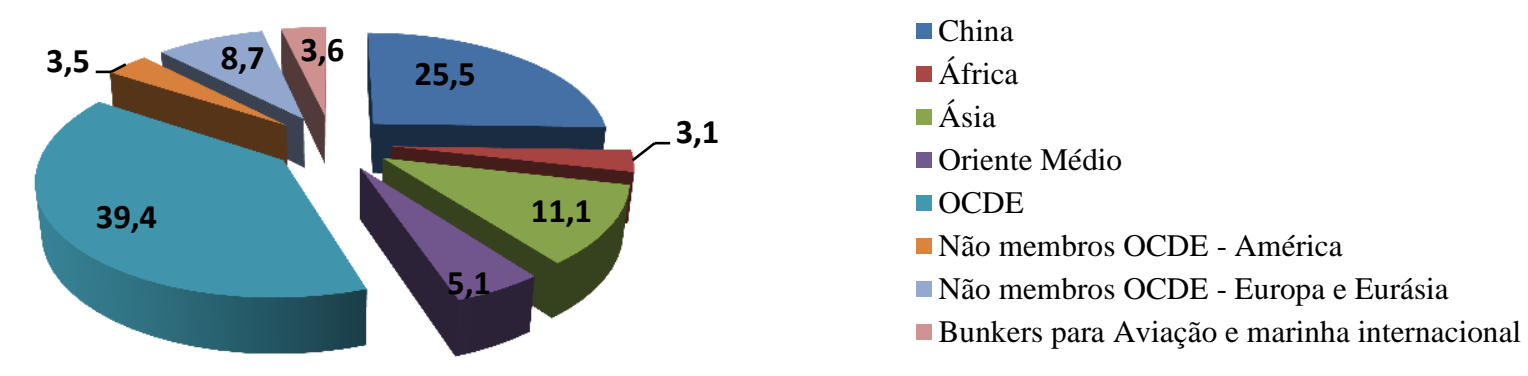

Fonte: IEA, Key World Energy Statistics 2013(modificado). Disponível em: <http://www.iea.org/>.

Figura 2.5 Participação regional na emissão de $\mathrm{CO}_{2}$ em 2011.

A oferta interna de energia (OIE) é toda quantidade de energia que se disponibiliza para ser transformada ou para consumo final, incluindo perdas anteriores de processo e posteriores na distribuição (MME/EPE, 2014a). A Figura 2.6 mostra a OIE no Brasil em 2013 e demonstra grande participação de recursos renováveis na matriz energética. No entanto, se nota que a matriz energética é predominantemente não renovável e fortemente dependente dos combustíveis fósseis e seus derivados com uma pequena participação da energia nuclear.

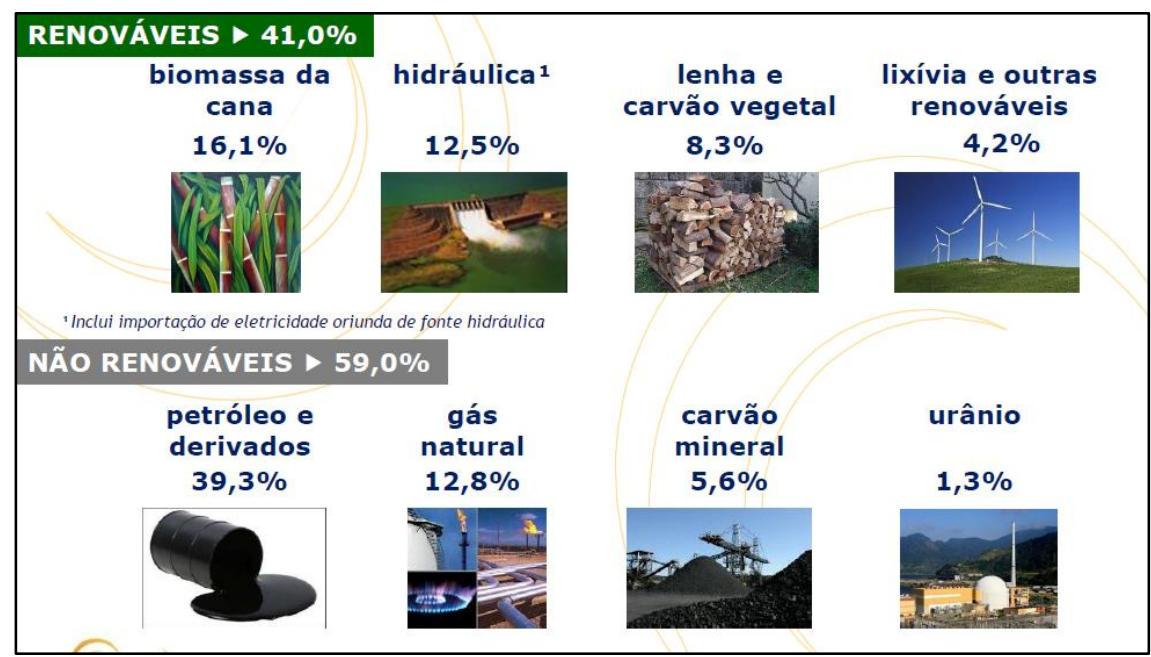

Fonte: MME - Ministério de Minas e Energia, EPE - Empresa de Pesquisa Energética, 2014a. Balanço Energético Nacional 2014: Ano base 2013 - Relatório Síntese. Disponível em <www.mme.gov.br>.

Figura 2.6 Oferta interna de energia no Brasil. 
Quando se observa mais especificamente a matriz de energia elétrica brasileira, Figura 2.7, nota-se que é preponderante o uso de recursos renováveis, uma vez que ela tem como base a geração hidrelétrica.

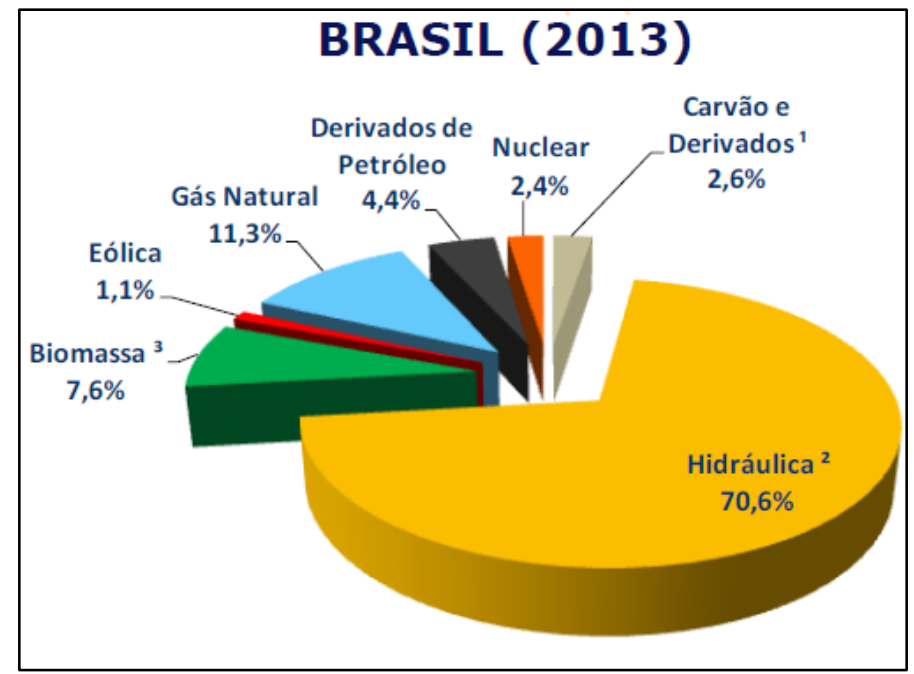

Fonte: MME - Ministério de Minas e Energia, EPE - Empresa de Pesquisa Energética, 2014a. Balanço Energético Nacional 2014: Ano base 2013 - Relatório Síntese. Disponível em <www.mme.gov.br>.

Figura 2.7 Matriz de energia elétrica gerada no Brasil em 2013.

\subsubsection{Geração hidrelétrica}

Durante décadas, o Brasil teve seu fornecimento de energia elétrica baseado em usinas hidrelétricas. Até o final da década de 90, cerca de 95\% da energia gerada no país provinha da hidroeletricidade. Atualmente, a geração hidráulica representa cerca de $70 \%$ na energia gerada. A Figura 2.8 mostra a redução da participação da energia hidrelétrica na matriz elétrica brasileira na última década. 


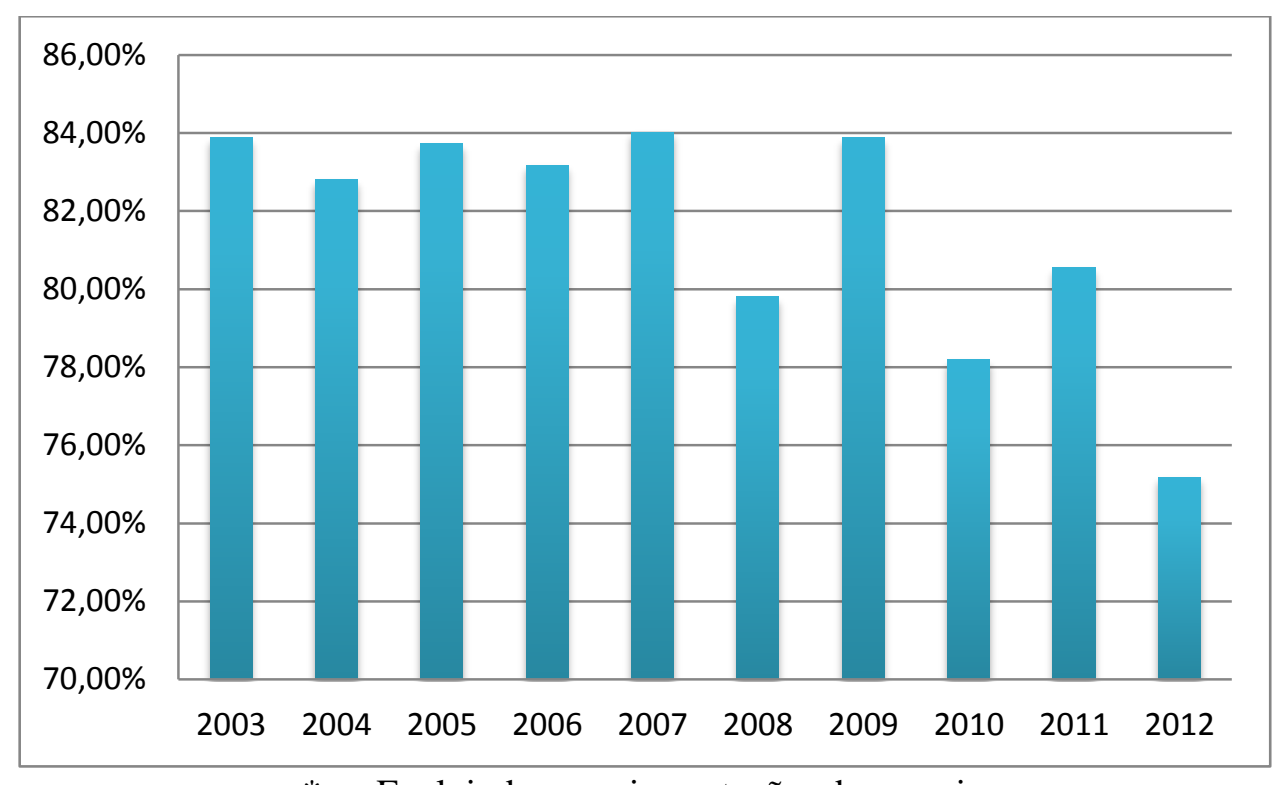

* Excluindo-se as importações de energia.

Fonte: MME - Ministério de Minas e Energia, EPE - Empresa de Pesquisa Energética. Balanço Energético Nacional 2013: Ano Base: 2012. Rio de Janeiro, MME/EPE, 2013a (modificado). Disponível em <www.mme.gov.br>. Acesso em: julho de 2014.

Figura 2.8 Variação anual da participação da hidroeletricidade na geração de energia elétrica total no Brasil de 2003 a 2012.

A EPE estima, dentro do horizonte do Plano Decenal de Energia (PDE), uma expansão hidrelétrica de $31 \mathrm{GW}$. Este total será insuficiente para atender o crescimento médio anual de cerca de $3.800 \mathrm{MW}$ no SIN, que irá resultar num total de $38 \mathrm{GW}$ de expansão ao final do período decenal (MME/EPE, 2014).

Porém, como se pode observar na Figura 2.9, o potencial hidrelétrico a ser explorado é limitado e o total aproveitado e inventariado já é muito maior do que o potencial que o Brasil ainda pode explorar. Do potencial hidráulico brasileiro, de $140 \mathrm{GW}$, cerca de $70 \%$ já foi explorado e muito do que ainda resta interfere em áreas protegidas, unidades de conservação e terras indígenas, e, portanto, dificilmente será explorado. 


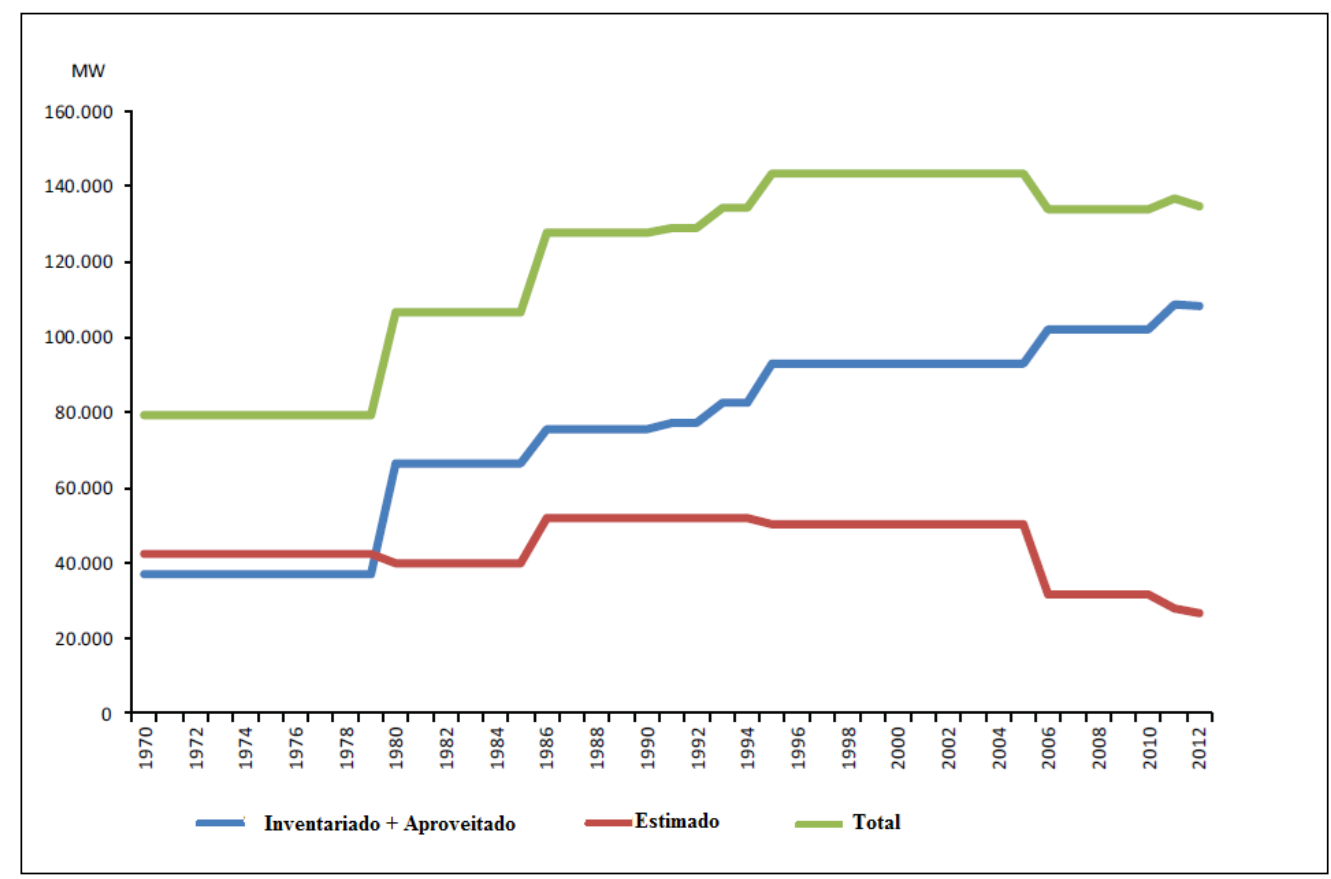

Fonte: MME - Ministério de Minas e Energia, EPE - Empresa de Pesquisa Energética. Balanço Energético Nacional 2013: Ano Base: 2012. Rio de Janeiro, MME/EPE, 2013a. Disponível em <www.mme.gov.br>. Acesso em: julho de 2014.

Figura 2.9 Potencial hidrelétrico brasileiro.

Um ponto relevante em relação à hidroeletricidade, é que a geração deve ser realizada em um local apropriado para que seja maximizada, que normalmente ocorre distante das cargas, o que significa altos custos com transmissão. Hoje no Brasil, linhas com grandes extensões são instaladas para trazer energia dos potencias hidráulicos no norte do País. Essas linhas trazem complexidade à operação, além de impactos ao meio ambiente.

A energia hidrelétrica, embora considerada uma forma de energia limpa e renovável, traz impactos ambientais e sociais em sua área de influência. A obra, em especial, a criação do lago da usina, com ou sem reservatório, tem um impacto ambiental, com a supressão de vegetação, e um impacto social na vida da comunidade que ali reside e deve ser remanejada. O Brasil possui uma legislação ambiental das mais rigorosas do mundo e adota medidas que reduzem os impactos provocados. Os custos da mitigação desses impactos e do licenciamento ambiental cresceram significativamente devido a essa maior preocupação.

Conforme ilustrado na Figura 2.10, a participação de geração de energia com fontes renováveis na Matriz Elétrica Brasileira caiu para 79,3\% em 2013, devido às condições 
hidrológicas desfavoráveis e ao aumento da geração térmica (MME/EPE, 2014a). A redução percentual da participação da hidroeletricidade ocorre principalmente por dois grandes fatores: os regimes pluviométricos adversos diminuem a geração de usinas já existentes e as restrições ambientais dificultam a implementação de novos projetos.

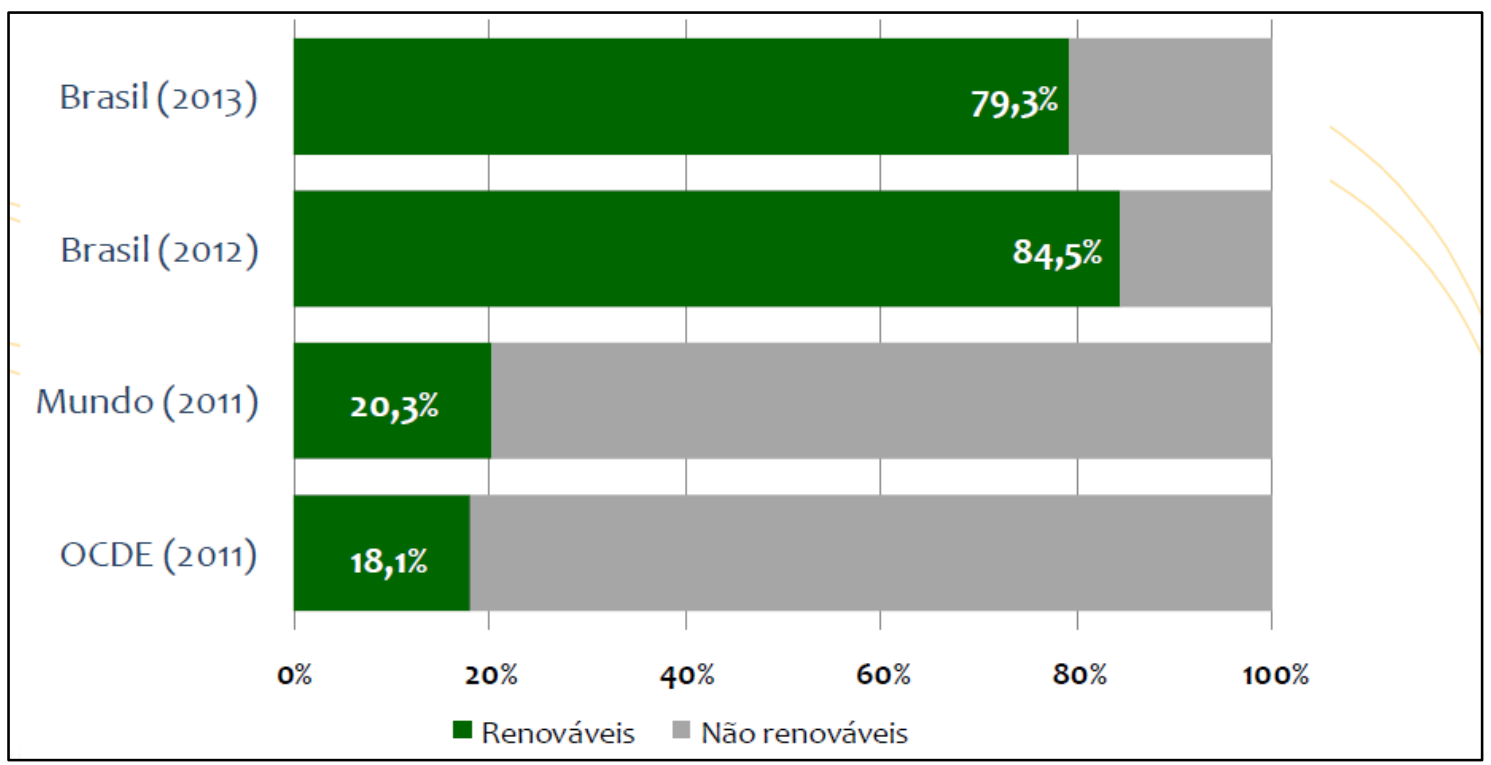

Fonte: MME - Ministério de Minas e Energia, EPE - Empresa de Pesquisa Energética, 2014a. Balanço Energético Nacional 2014: Ano base 2013 - Relatório Síntese. Disponível em <www.mme.gov.br>.

Figura 2.10 Participação de renováveis na matriz elétrica.

\subsubsection{Complementação térmica}

Um sistema de geração exclusivamente hidráulico apresenta bastante vulnerabilidade em virtude da dependência de eventos hidrológicos, que podem alterar de maneira drástica a energia armazenada. Uma forma de mitigar os riscos hidrológicos é a diversificação da matriz. Tal processo tem sido feito ao longo das últimas décadas com a inserção de fontes térmicas a carvão, óleo e gás natural, transformando a matriz elétrica brasileira em hidrotérmica, como mostra a Tabela 2.3. É importante ressaltar que, enquanto o mundo busca diminuir a participação desse tipo de fonte poluente, o Brasil vem aumentando a participação térmica. 
Tabela 2.3 Capacidade de geração no Brasil.

\begin{tabular}{|lccc|}
\hline \multicolumn{1}{|c}{ Empreendimentos em Operação } \\
\hline Tipo & Quantidade & $\begin{array}{c}\text { Potência Instalada } \\
\text { (MW) }\end{array}$ & Participação (\%) \\
\hline Central Geradora Hidrelétrica & 485 & 303 & 0,23 \\
\hline Central Geradora Eólica & 232 & 4.980 & 3,72 \\
\hline Pequena Central Hidrelétrica & 472 & 4.753 & 3,55 \\
\hline Central Geradora Solar Fotovoltaica & 317 & 15 & 0,01 \\
\hline Usina Hidrelétrica & 201 & 84.169 & 62,81 \\
\hline Usina Termelétrica (Fóssil) & 1.385 & 25.454 & 19,0 \\
\hline Usina Termelétrica (Biomassa) & 504 & 12.341 & 9,2 \\
\hline Usina Termonuclear & 2 & 1.990 & 1,48 \\
\hline Total & $\mathbf{3 . 5 9 8}$ & $\mathbf{1 3 4 . 0 0 8}$ & $\mathbf{1 0 0 , 0 0}$ \\
\hline
\end{tabular}

Fonte: ANEEL (Banco Informações da Geração), janeiro de 2015 (modificado).

No contexto de energia limpa, a geração térmica utilizando biomassa, resíduos sólidos ou biogás poderia ser incluída nesse portfólio hidrotérmico. No entanto, a biomassa tem uma limitação sazonal, já que a safra só ocorre em certos períodos no ano e os investimentos necessários para o desenvolvimento desta fonte estão sujeitos à volatilidade do setor (MME/EPE, 2012). O uso da biomassa no Brasil tem um papel de destaque na matriz energética, mas no contexto de energia elétrica, sua participação é reduzida.

\subsubsection{O desenvolvimento da geração eólica no Brasil}

O Programa de Incentivo às Fontes Alternativas de Energia Elétrica (Proinfa), instituído em 2004 (BRASIL, 2004a), ofereceu um ambiente favorável à expansão da energia eólica. Ainda no sentido de incentivar esse tipo de energia, em 14 de dezembro de 2009, foi realizado o segundo leilão de energia de reserva (LER), exclusivo para energia eólica, tendo sido contratadas 71 novas usinas, com potência instalada total de $1805,7 \mathrm{MW}$, ao preço médio de 148,39 R \$/MWh (ANEEL, 2015). Nesse mesmo ano, foi realizado o leilão da usina hidrelétrica de Belo Monte, ao preço de R \$78,00 /MWh, ou seja, a energia advinda das eólicas era quase duas vezes mais cara do que a energia contratada de Belo Monte. No ano anterior, 2008, o LER adquiriu energia proveniente de biomassa ao preço médio de R \$ 58,84/MWh, ou seja valor 40\% menor do que o resultante do leilão exclusivo 
para eólicas. Também ocorreram leilões específicos para fontes alternativas (LFA), onde as eólicas competiam apenas com geração advinda de pequenas centrais hidrelétricas $(\mathrm{PCH})$ e biomassa. Posteriormente, mudanças no panorama econômico mundial permitiram uma queda significativa no preço de aerogeradores levando a um incremento da sua participação no País.

Desde 2010, a geração eólica já dispensa os incentivos governamentais e participa de forma direta dos leilões de energia sendo, inclusive, a fonte que mais cresceu em participação nos leilões desde 2009 (MME/EPE, 2012). Na Figura 2.11, vê-se a evolução da geração por essa fonte no país. Porém, deve-se ter cautela ao considerar a fonte eólica como uma possível substituta da energia térmica, haja vista que ela é considerada uma fonte intermitente.

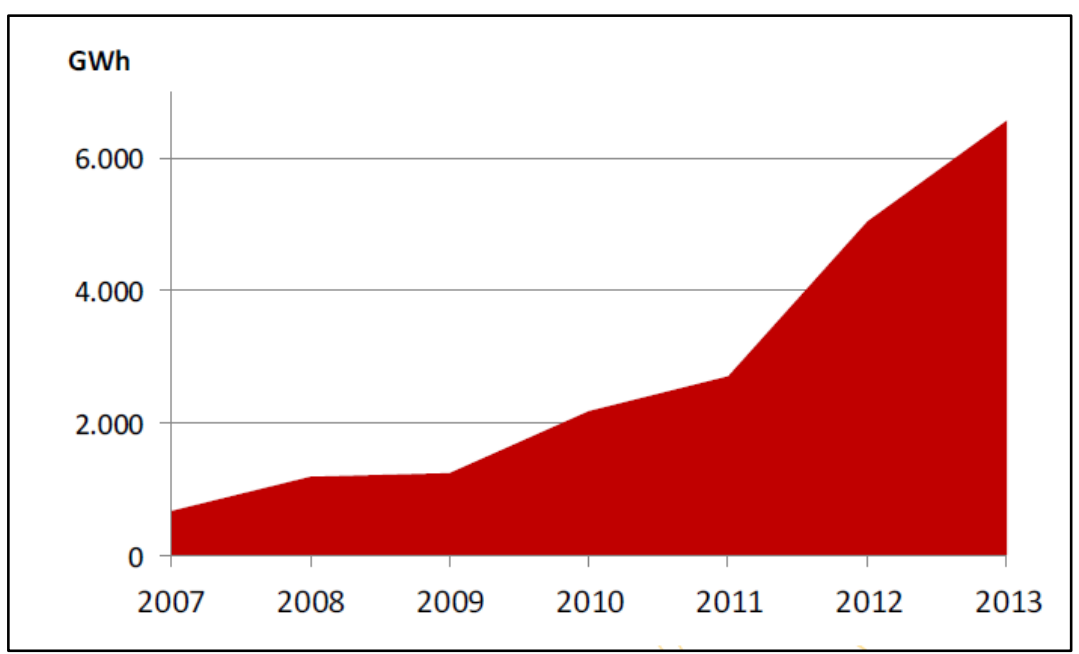

Fonte: MME - Ministério de Minas e Energia, EPE - Empresa de Pesquisa Energética, 2014a. Balanço Energético Nacional 2014: Ano base 2013 - Relatório Síntese. Disponível em <www.mme.gov.br>.

Figura 2.11 Evolução da geração eólica no Brasil.

\subsection{NOVOS DESAFIOS PARA O SETOR ELÉTRICO BRASILEIRO}

Atualmente, a necessidade de crescimento do parque gerador, a importância de diversificação ainda maior da matriz, a escassez do potencial hidráulico a ser aproveitado e as questões ambientais se colocam como novos desafios para o setor. 
O relatório do Comitê americano de avaliação do clima, de maio de 2014 (NCA, 2014), mostra os impactos que eventos climáticos intensos, atribuídos às mudanças climáticas, trazem à geração, transmissão e distribuição de energia. Eventos como furacões e tempestades afetam o transporte de combustível, bem como equipamentos de transmissão, como redes e subestações. A falta de água em algumas regiões ameaça a produção de energia nuclear, bem como a de hidrelétricas (GREENTECHMEDIA, 2014).

No Plano Nacional sobre Mudança do Clima (BRASIL, 2007), uma das diretrizes propostas pelo comitê interministerial é de manter elevada a participação de energia renovável na matriz elétrica, preservando a posição de destaque que o Brasil sempre ocupou no cenário internacional. Para alcançar tal objetivo e permanecer entre os países com maior participação de energia renovável e limpa, o Brasil deve investir em outras fontes renováveis, buscando alternativas à tradicional fonte de geração hidrelétrica.

A diversificação da matriz energética, além de trazer maior segurança, favorece a competitividade da economia, a modicidade tarifária e a sustentabilidade socioambiental. Assim, surge a necessidade da utilização das demais fontes renováveis de geração. Contudo, existem obstáculos que restringem a participação expressiva dessas tecnologias, principalmente o fato de que muitas não são economicamente competitivas sem que haja subsídios (MME/EPE, 2012). Embora muitas dessas fontes renováveis sejam mais caras que as habituais, o modelo hidrotérmico brasileiro causa uma forte dependência ao regime de chuvas, expondo o mercado a preços altos quando as condições climáticas são adversas. Devido à crise hídrica que se iniciou em 2014, os preços do mercado de curto prazo passaram de R\$ 800/MWh (CCEE, 2015).

Essas fontes se mostram necessárias quando se analisa sucintamente as principais premissas para o setor elétrico brasileiro: o Brasil precisa de mais energia para crescer; o potencial hidrelétrico já não é mais suficiente para suprir toda a demanda; há necessidade de diversidade na matriz elétrica; a modicidade tarifária poderia se beneficiar com a inserção de novas fontes de energia; e o modelo convencional de complemento térmico vai de encontro às questões ambientais, já que o impacto ao meio ambiente, que era uma preocupação menor há algumas décadas, agora dita o ritmo de quase todas as obras de infraestrutura no País. Portanto, investir em fontes de energia renovável é a melhor forma de atender à demanda crescente, considerando a sustentabilidade. 


\subsection{POTENCIAL DA ENERGIA SOLAR}

Em 90 minutos, a luz solar que chega à superfície da Terra é capaz de produzir energia para suprir toda a demanda do planeta durante um ano (IEA, 2011). A energia advinda do Sol, anualmente $1,5 \times 10^{18} \mathrm{kWh}$, é a principal fonte de vida do Planeta. Quase todos os tipos de energia renovável utilizados são de alguma forma relacionados ao Sol. A energia hidrelétrica depende do ciclo de chuva, que só acontece devido ao Sol, o mesmo acontece com a energia eólica e com a biomassa.

A geração de energia elétrica, utilizando a energia solar, provem da conversão da luz e do calor do Sol em eletricidade, usando sistemas fotovoltaicos (FV) ou energia solar concentrada (CSP). Essa forma de geração contribui para a redução de emissões de $\mathrm{CO}_{2}$ na natureza pelo uso de energia, já que é renovável e limpa. Em todo o mundo, a energia fotovoltaica conectada à rede é atualmente a tecnologia de geração de energia que cresceu mais rapidamente. De 2006 a 2011, aumentou 58\% por ano em capacidade instalada (MALAGUETA et al., 2013).

O emprego da energia solar fotovoltaica pode acontecer de três formas principais: em sistemas isolados, ou seja, sem conexão à rede elétrica; na geração distribuída interligada à rede elétrica (GDFV); e em usinas fotovoltaicas (UFV). As usinas solares consistem na instalação de uma grande quantidade de painéis solares em uma determinada área. A GDFV é uma forma da chamada geração distribuída. A micro e a minigeração distribuída, estabelecidas na Portaria ANEEL nº482/2012, consistem na produção de energia elétrica a partir de pequenas centrais geradoras que utilizam fontes com base em energia hidráulica, solar, eólica, biomassa ou cogeração qualificada, conectadas à rede de distribuição por meio de instalações de unidades consumidoras (ANEEL,2014b).

Sistemas fotovoltaicos conectados a rede oferecem geração de energia elétrica limpa e ecologicamente sustentável. Uma vantagem da energia solar é a sua possibilidade de utilização de forma distribuída, promovendo o desenvolvimento social e econômico, com o acesso à energia renovável, e evitando gastos e impacto ambiental com linhas de transmissão, além de evitar o uso de grandes áreas dedicadas a geração de energia, deixando-as disponíveis para a agricultura ou pecuária. No entanto, esse tipo de aplicação é mais comumente associado a países desenvolvidos, enquanto aplicações isoladas são mais 
usuais em países em desenvolvimento, onde muitas pessoas ainda não tem acesso à energia elétrica.

Muitos países já implantaram esses tipos de tecnologia e tiveram êxito em vários programas, porém, no Brasil essa tecnologia ainda se restringe a poucos MW. Até 2012, a potência instalada de energia solar fotovoltaica no Brasil era, em maioria, em sistemas isolados. Com a Resolução Normativa ANEEL nº482/2012, que será explicada no decorrer do trabalho, esse panorama mudou.

\subsubsection{Geração centralizada}

Um sistema elétrico tradicional é aquele no qual a geração ocorre de forma centralizada, em grandes usinas, e essa energia é transmitida por extensas linhas de transmissão até os centros de consumo (ABREU et al., 2010).

A geração de energia por meio de painéis fotovoltaicos pode ser realizada de forma centralizada, em um local com boas condições de irradiação solar, sendo possível uma capacidade instalada maior do que quando instalada de forma distribuída. Dessa forma, ainda é necessária a utilização do sistema de transmissão e distribuição para levar a energia gerada aos consumidores.

As usinas solares fotovoltaicas podem apresentar potências instaladas na ordem de $\mathrm{kWp}$ até MWp. Uma grande usina fotovoltaica em operação é a Agua Caliente, instalada no Arizona, nos Estados Unidos, com potência de $250 \mathrm{MWp}$ e previsão de aumento para até 290 MWp (FIRST SOLAR, 2012). Outro exemplo é a usina solar Topaz em San Obispo na Califórnia com capacidade instalada de $550 \mathrm{MWp}$ e que entrou em operação no final de 2014 (FIRST SOLAR, 2014). Este avanço nas instalações de usinas fotovoltaicas se dá, entre outros motivos, pelo crescente investimento na área e a consequente redução de custos dos equipamentos. Estima-se que, desde 2009, os custos de instalação de uma usina fotovoltaica tenham diminuído 40\% (RENI, 2012), devido principalmente à queda dos preços dos módulos, impulsionados pela produção asiática. 


\subsubsection{Geração distribuída}

Contrapondo-se ao modelo tradicional de geração e consumo de energia elétrica, há o conceito de geração distribuída (GD). Considera-se geração distribuída aquela que: (a) está conectada à rede de distribuição; (b) está conectada ao lado de um consumidor conectado a algum ponto do sistema elétrico; (c) supre cargas elétricas de uma instalação eletricamente isolada; ou (d) está conectada diretamente à rede de transmissão, desde que, neste caso, ela não possa ser considerada como pertencente à geração centralizada (SEVERINO, 2008). Na Figura 2.12, é possível ver os diferentes pontos de inserção das duas formas de geração.

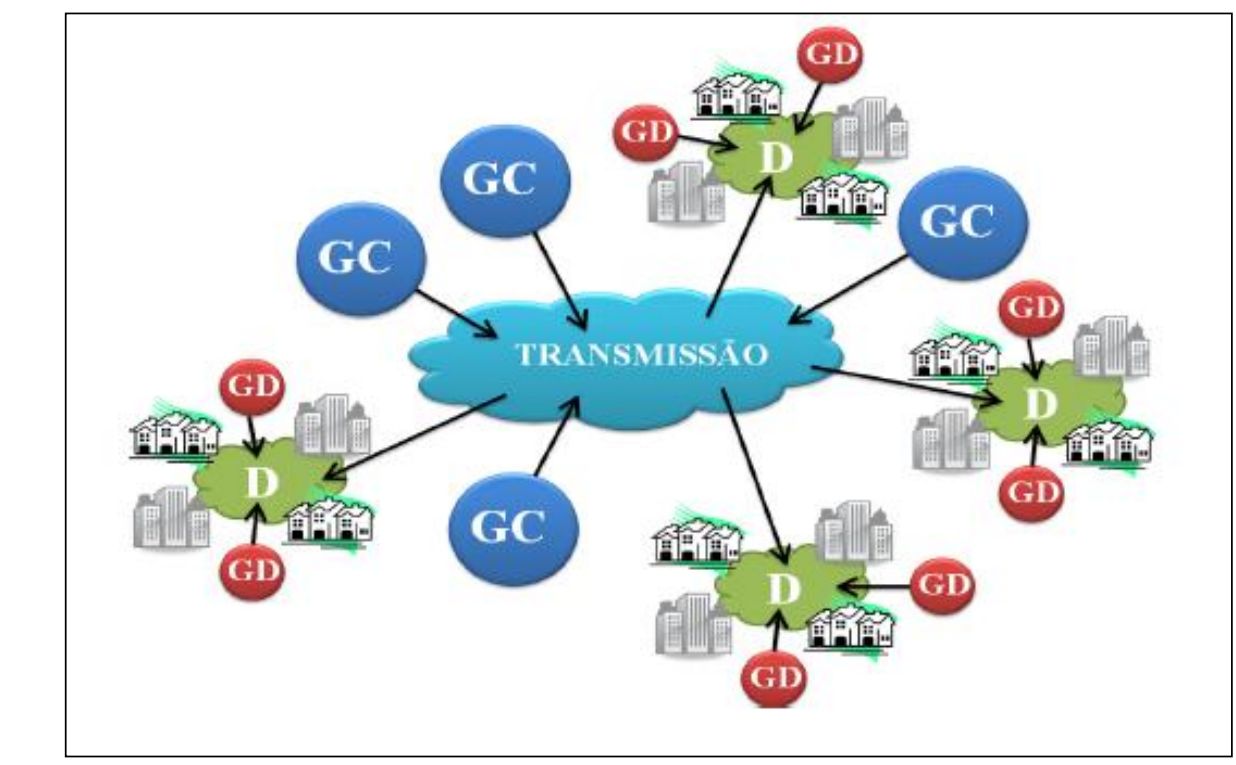

Fonte: ABREU, Y. V.; OLIVEIRA, M. A. G.; GUERRA, S. M. G. Energia, Sociedade e Meio Ambiente. Brasil, 2010.

Figura 2.12 Geração Centralizada (GC) e Geração Distribuída (GD).

A GD pode contribuir para a redução das perdas associadas à transmissão da energia, já que a geração e a carga estão mais próximas ou localizadas em um mesmo ponto da rede. É relevante apontar que em 2012, o crescimento relativo do consumo final de eletricidade no Brasil foi inferior ao crescimento relativo da energia elétrica disponibilizada, o que indica um aumento das perdas no sistema (MME/EPE, 2013b). Outra vantagem da geração distribuída é o fato de contribuir para a eficiência energética, já que, ao diminuir o carregamento dos alimentadores, diminuem-se as perdas. Um ponto muito positivo é que, com a implantação desse tipo de geração, é possível uma postergação de investimentos em expansão nos sistemas de distribuição, e, ainda, contribui para a modicidade tarifária. 
Dentre as fontes potenciais para implantação da GD, a energia fotovoltaica é a que mais se destaca (AFONSO, 2012). Isto porque, além de ser compacta e ter baixo impacto ambiental, a fonte fotovoltaica tem, de certa forma, uma implantação ágil e simples, representando uma alternativa rápida para disponibilizar energia elétrica próxima aos centros de carga.

Além disso, a oferta da energia solar apresenta comportamento parecido com perfis de consumo de determinadas cargas. Em prédios comerciais, por exemplo, os aparelhos de ar condicionado que representam parte expressiva da demanda, têm uma curva de consumo que acompanha uma curva diária típica de irradiação solar (SHAYANI, 2010), havendo coincidência entre a maior demanda elétrica e a maior intensidade solar. A implantação de painéis fotovoltaicos faria com que esses edifícios viessem a ter capacidade de reduzir os picos de demanda que ocorrem durante o dia. Assim, a geração de energia solar fotovoltaica distribuída (GDFV) pode se tornar uma forma de suprir parte da demanda existente nos grandes centros urbanos.

Outro fator interessante da energia solar fotovoltaica, distribuída ou não, é a natureza complementar entre os sistemas FV e os picos de energia hidrelétrica, devido à complementariedade entre luz solar e chuva (MITSCHER et al., 2012). Isso se torna relevante no panorama atual brasileiro, pois as usinas hidrelétricas que estão sendo construídas não possuem reservatório de regularização, a fim de diminuir o impacto ambiental produzido por elas.

\subsection{INSERÇÃO DA GERAÇÃO FOTOVOLTAICA NA MATRIZ MUNDIAL}

A tecnologia fotovoltaica tem tomado um espaço importante no setor elétrico de vários países nos últimos anos. Mundialmente, pelo menos 160 TWh foram produzidos em 2014 por tecnologia FV em sistemas instalados e comissionados até janeiro de 2014. Isso representa $0,85 \%$ da demanda de eletricidade do planeta, embora alguns países tenham atingido porcentagens mais significativas (IEA - PVPS, 2014).

O desenvolvimento dos sistemas FV nos últimos dez anos foi impulsionado pela utilização de políticas de suporte, buscando diminuir a diferença do custo da eletricidade FV e o preço de fontes convencionais de energia. Esses mecanismos de suporte foram diversos 
dependendo das especificidades do local e evoluíram para lidar com variações inesperadas do mercado e mudanças políticas (IEA, 2013b). Essas políticas públicas são temporárias (mesmo que durem muitos anos), mas visam reduzir o preço com o aumento da demanda, até o momento que a paridade tarifária é alcançada e o subsídio torna-se desnecessário.

Os primeiros países a investir em energia solar tiveram como motivação inicial a combinação de preocupação ambiental, base de geração fóssil e tradição de inovação tecnológica, que foram fundamentais para dar sustentação a uma política baseada em leis de obrigatoriedade de compra de energia e subsídios governamentais. Esses países apostaram na energia fotovoltaica como solução promissora e decidiram subsidiar essa tecnologia para estimular a redução de preços e, consequentemente, sua viabilidade econômica.

Há algumas décadas os Estados Unidos foi a nação que mais investiu na tecnologia fotovoltaica, sendo que em 1980, produzia $85 \%$ dos painéis solares, em termos mundiais. Entretanto, em 2005 essa parcela reduziu-se a menos de 10\% (QUASCHNING, 2011) e nos anos posteriores, até o ano de 2012, a Europa assumiu a liderança absoluta em relação às novas instalações. A partir de 2012, o mercado chinês se coloca como líder no panorama mundial. O caminho traçado pelos países que iniciaram o desenvolvimento da energia solar fotovoltaica no mundo pode servir de exemplo para o Brasil enfrentar os novos desafios para o setor elétrico nacional, discutidos na seção 2.3.

\subsubsection{Países com maior produção de energia solar fotovoltaica}

Pelo menos 36,9 GW de sistemas fotovoltaicos foram instalados e conectados à rede no mundo em 2013 (IEA - PVPS, 2013). A Ásia lidera o quadro, com mais de 59\% do Mercado FV mundial. Os 29 membros do Photovoltaic Power System Programme (IEAPVPS $)^{2}$ representam 123,2 GW de FV acumulado, em sua maior parte conectado à rede, no final de 2013. Outros países, não participantes do PVPS representam pelo menos 10,8 GW adicionais, a maioria na Europa. A Figura 2.13 mostra o vertiginoso crescimento que essa

2 Austrália, Áustria, Bélgica, Canadá, China, Dinamarca, EPIA (European Photovoltaic Industry Association), União Europeia, França, Alemanha, International Copper Association, Israel, Itália, Japão, Coréia, Malásia, México, Holanda, Noruega, Portugal, SEIA (Solar Energy Industries Association), SEPA (Solar Electric Power Association), Espanha, Suécia , Suíça, Tailândia, Turquia, Reino Unido, Estados Unidos. 
fonte vem apresentando nos último dez anos no mundo, chegando a quase $140 \mathrm{GWp}$ de capacidade instalada.

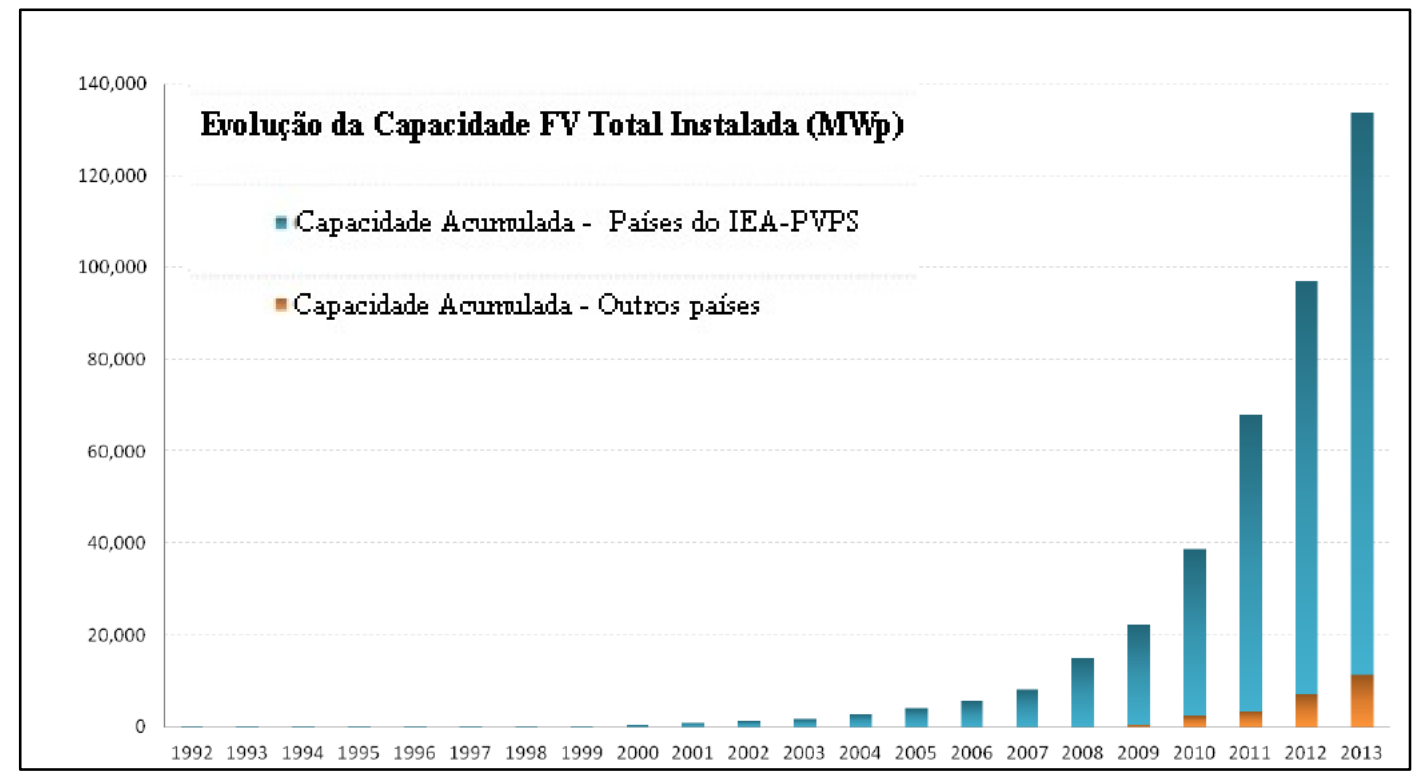

Fonte: IEA-PVPS, 2014b (modificado). A Snapshot of Global PV 1992 - 2013. Report IEA-PVPS T1-24:2014. Disponível em: 〈www.iea-pvps.org>.

Figura 2.13 Evolução da Capacidade Solar Fotovoltaica Total Instalada de 1992 a 2013 (MWp).

O Relatório Anual da Agência Internacional de Energia (IEA) aponta os países com maior capacidade fotovoltaica adicionada em 2013 e os países com maior capacidade instalada total dessa fonte (Tabela 2.4).

Tabela 2.4 Países com maior Capacidade Solar Fotovoltaica Total Instalada em 2013 $(\mathrm{GW})$ e Capacidade Total Acumulada.

\begin{tabular}{|lllll|}
\hline & \multicolumn{2}{c}{ Instalações $(\mathbf{G W})$} & \multicolumn{2}{c|}{ Capacidade Total Instalada (GW) } \\
\hline $\mathbf{1}$ & China & 11,3 & Alemanha & 35,5 \\
\hline $\mathbf{2}$ & Japão & 6,9 & China & 18,3 \\
\hline $\mathbf{3}$ & EUA & 4,8 & Itália & 17,6 \\
\hline $\mathbf{4}$ & Alemanha & 3,3 & Japão & 13,6 \\
\hline $\mathbf{5}$ & Itália & 1,5 & EUA & 12,0 \\
\hline $\mathbf{6}$ & Índia* & 1,1 & Espanha & 5,6 \\
\hline $\mathbf{7}$ & Romênia* & 1,1 & França & 4,6 \\
\hline $\mathbf{8}$ & Grécia* & 1,0 & Austrália & 3,3 \\
\hline
\end{tabular}




\begin{tabular}{|lllll|}
\hline & \multicolumn{2}{c}{ Instalações $(\mathbf{G W})$} & \multicolumn{2}{c|}{ Capacidade Total Instalada $(\mathrm{GW})$} \\
\hline $\mathbf{9}$ & Reino Unido & 1,0 & Bélgica & 3,0 \\
\hline $\mathbf{1 0}$ & Austrália & 0,9 & Reino Unido & 2,9 \\
\hline
\end{tabular}

*Não participa do PVPS

Fonte: IEA-PVPS, 2014b (modificado). A Snapshot of Global PV 1992 - 2013. Report IEA-PVPS T1-24:2014. Disponível em: 〈www.iea-pvps.org>.

A seguir são apresentados detalhes dos seis países com maior capacidade solar fotovoltaica instalada em suas matrizes e suas principais medidas regulatórias que contribuíram para incentivar o desenvolvimento desse tipo de tecnologia.

\subsubsection{Alemanha}

A Alemanha é pioneira na utilização da energia solar distribuída e é um dos países com maior penetração de energia solar fotovoltaica no mundo atualmente. Essa fonte é responsável por $25 \%$ da demanda no país. Se compararmos com a parcela que ela ocupava há 20 anos (5\%), nota-se que o país é um exemplo de como inserir essa fonte na matriz energética. Em 9 de Junho de 2014, um feriado no país, a Alemanha supriu 50,1\% de sua demanda elétrica diária apenas com energia solar, estabelecendo um novo recorde para a fonte (Fraunhofer $\left.\operatorname{ISE}^{3}\right)$.

A Alemanha continua sendo o maior mercado solar da União Europeia, mas caiu de primeiro para quarto no mundo, adicionando 3,3 GW, depois de três anos com média em torno de 7,6 GW. Com um total de aproximadamente $36 \mathrm{GW}$ (

Tabela 2.4), a Alemanha ainda tem a maior capacidade instalada do mundo (21\% dos 174.482 GW instalados). Na Figura 2.14, vê-se a rápida expansão na capacidade instalada de instalações fotovoltaicas na Alemanha na última década.

\footnotetext{
${ }^{3}$ Fraunhofer Institute for Solar Energy Systems ISE (Fraunhofer ISE) é um instituto localizado em Freiburg, Alemanha, que executa pesquisas científicas e de engenharia, para todas as áreas que englobam energia solar.
} 


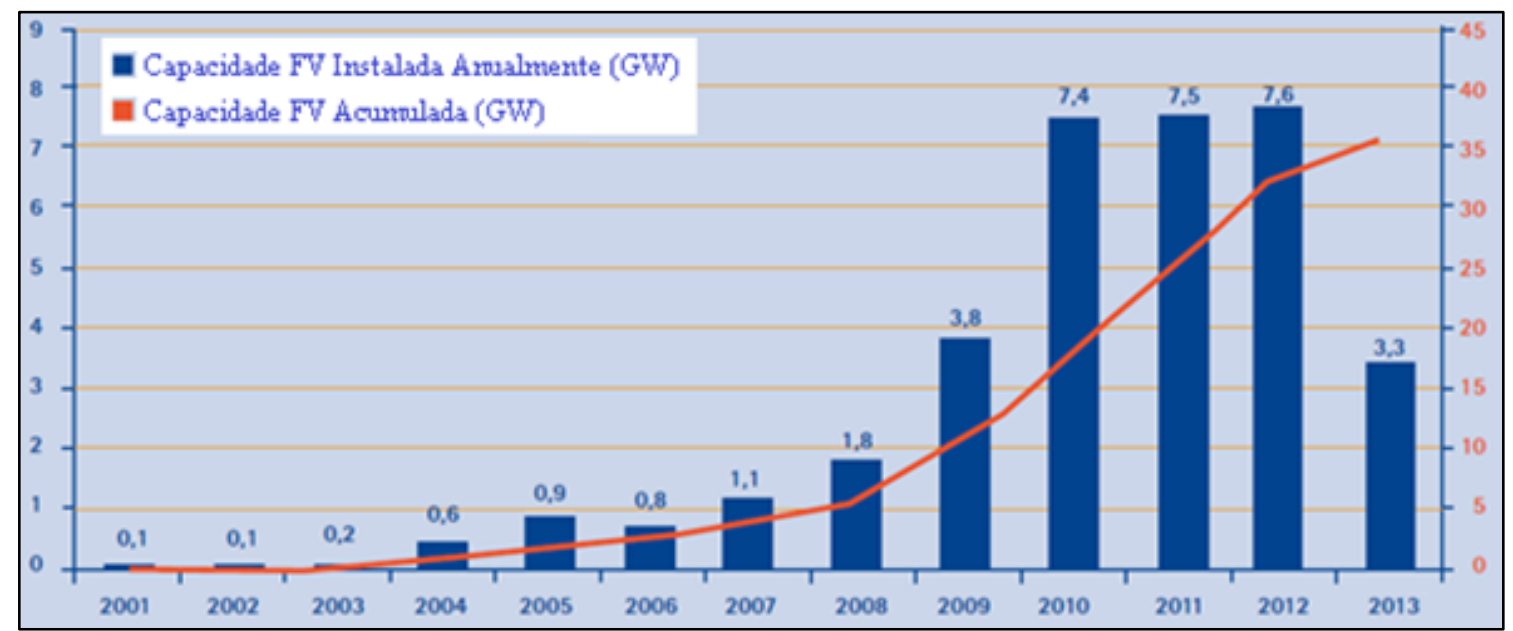

Fonte: IEA-PVPS, 2014a (modificada). Annual report 2013. Report IEA-PVPS T1-20:2014. Disponível em: <www.iea-pvps.org>.

Figura 2.14 Evolução da capacidade instalada de energia FV conectada a rede na Alemanha

Na Figura 2.15 observa-se que a energia fotovoltaica é hoje a segunda fonte com maior capacidade instalada na Alemanha, atrás apenas de geração térmica utilizando combustíveis fósseis.

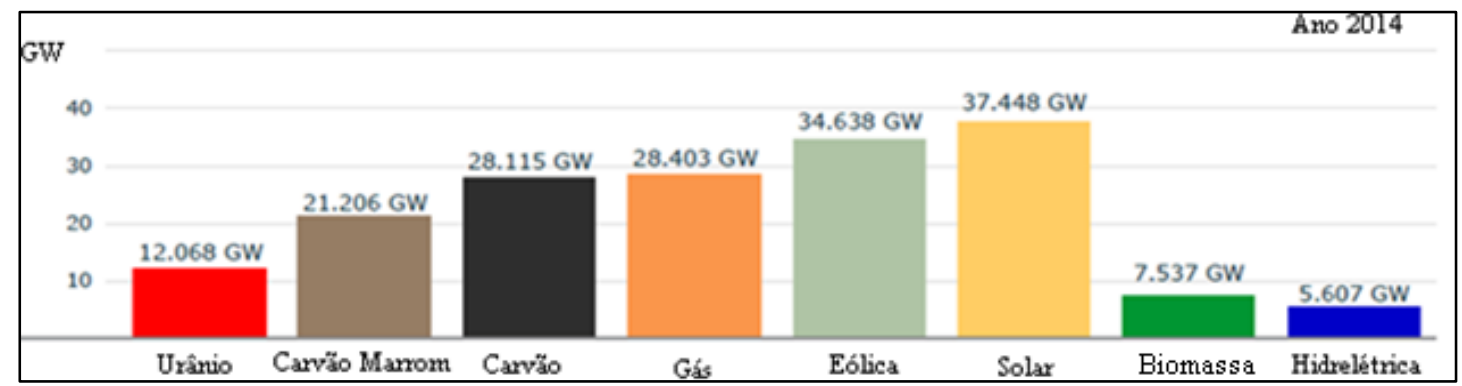

Fonte: ISE - Fraunhofer Institute, 2014 (modificado).

Figura 2.15 Matriz Elétrica Alemã em 2014

Esse desenvolvimento se deve a várias medidas implementadas pelo governo alemão de forma a incentivar essa tecnologia. Incialmente, na década de 90, o país promoveu um programa de instalação de painéis fotovoltaicos conectados à rede instalados em telhados residenciais. A meta inicial era de 1.000 telhados, mas com o sucesso do programa a meta foi aumentada para 100.000 telhados, que ultrapassou a meta prevista de $350 \mathrm{MWp}$. Em conjunto foi criado o programa de empréstimos "Solarstrom Erzeugen - Solar Power Generation" (IEA-PVPS, 2007). 
Além desses programas pontuais, foi criado o Código das Fontes Renováveis de Energia (Erneuerbare Energien-Gesetz, EEG), que foi o instrumento legal essencial para dar suporte à geração de eletricidade de fontes renováveis. Ele foi criado no ano 2000 e vem sendo revisado anualmente para se adequar às novas realidades e tecnologias.

A regulamentação da inserção da energia gerada por fontes renováveis se baseou em um sistema de tarifa prêmio ou feed-in-tarif (FiT). Nesse sistema, as distribuidoras de energia são obrigadas a comprar toda essa energia advinda de fonte renovável a preços pré-fixados. Na seção 3.1.1, esse mecanismo é explicado em maior detalhe. O acréscimo na conta do consumidor para subsidiar a tarifa prêmio era um percentual pequeno, atingindo valores máximos na ordem de 5\% (AFONSO, 2012). Como resultado direto da política de subsídio, em alguns anos, o custo das instalações fotovoltaicas apresentou um declínio constante que, em conjunto com o aumento no preço da energia elétrica, culminou em um crescimento expressivo do número de instalações, conforme mostra a Figura 2.16.

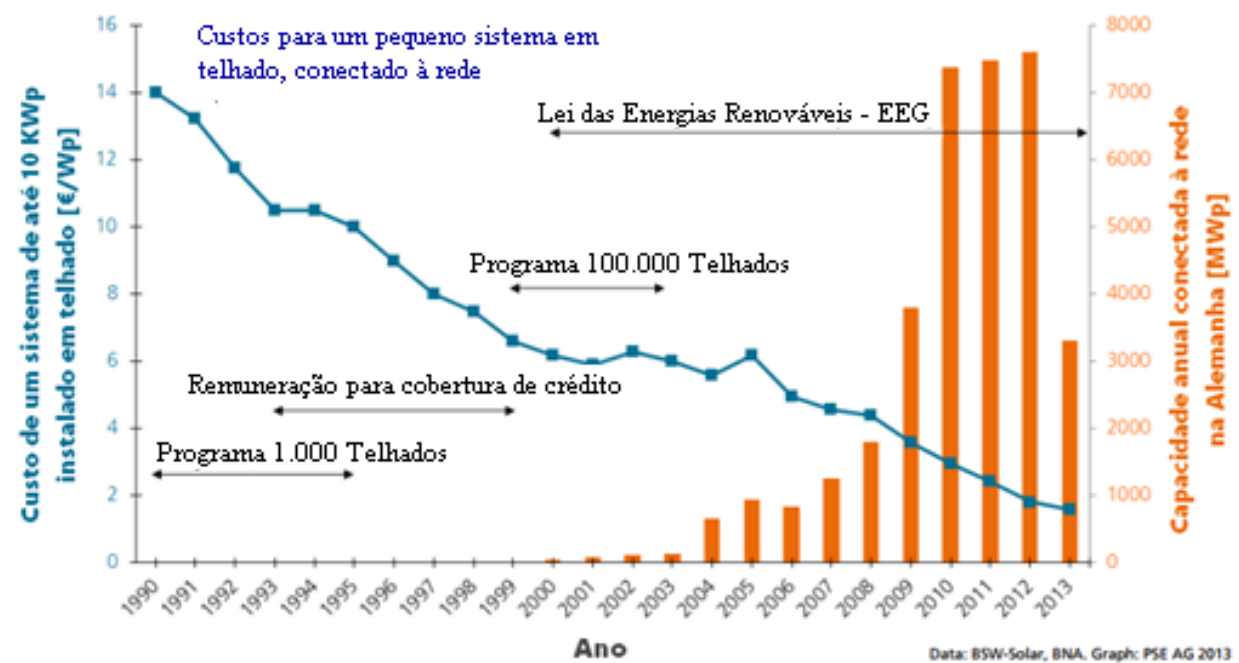

Fonte: ISE - Fraunhofer Institute for Solar Energy Systems. Photovoltaics Report, 2014 (modificado). Disponível em: < http://www.ise.fraunhofer.de>. Acesso em: Agosto de 2014.

Figura 2.16 Evolução do custo das instalações (€/Wp) e da capacidade total instalada (MWp) na Alemanha

Na sua revisão de 2008, o EEG foi alterado para prever a redução de preço dos sistemas, estipulando uma redução na tarifa prêmio de novas instalações na ordem de 5\% a $8 \%$ ao ano (IEA-PVPS, 2006). Os principais objetivos do código são: 
- Segurança no investimento através de tarifas prêmio (feed-in tariffs) e prioridade de conexão à rede: As plantas de energia renovável tem prioridade na venda e no transporte de energia. Na prática, isso significa que durante 20 anos eles têm remuneração garantida da energia produzida. Assim, plantas de pequeno e médio porte têm novo acesso garantido ao mercado de eletricidade; e

- Inovação é encorajada: Uma redução regular nas tarifas de energia elétrica para novas instalações obriga o mercado a se adequar e se tornar mais eficiente, ou seja, o custo de um sistema novo deve se tornar mais barato. Essa redução visa atingir a paridade tarifária, quando incentivos não são mais necessários.

Em 2009, a redução anual da tarifa foi substituída por um mecanismo que determina valores diferentes de acordo com metas de crescimento do mercado, ou seja, quando certa quantidade de energia é adquirida, a tarifa para novos empreendimentos é ajustada para um valor menor (AFONSO, 2012). Assim, ela teria um acréscimo ou decréscimo de forma a ajustá-la a variações anuais do mercado, com limites pré-definidos.

O acréscimo na conta dos consumidores, com a redução dos valores das tarifas prêmio, também diminuiu e a tendência é que esse valor continue a decrescer, enquanto o custo de energia vinda de combustíveis fósseis aumente devido à escassez dessa fonte e dos custos ambientais que dela decorrem.

A Figura 2.17 mostra o comportamento da tarifa prêmio desde 2001 e a capacidade adicionada ao sistema alemão. Os valores são garantidos para o período de 20 anos (IEAPVPS, 2013). Havia apenas uma única tarifa disponível para projetos fotovoltaicos até 2003. A partir de 2004, a Alemanha introduziu tarifas diferenciadas por tamanho de planta e por aplicação. Assim, são apresentados, a partir de 2004, os limites superiores e inferiores das tarifas prêmio praticadas. 


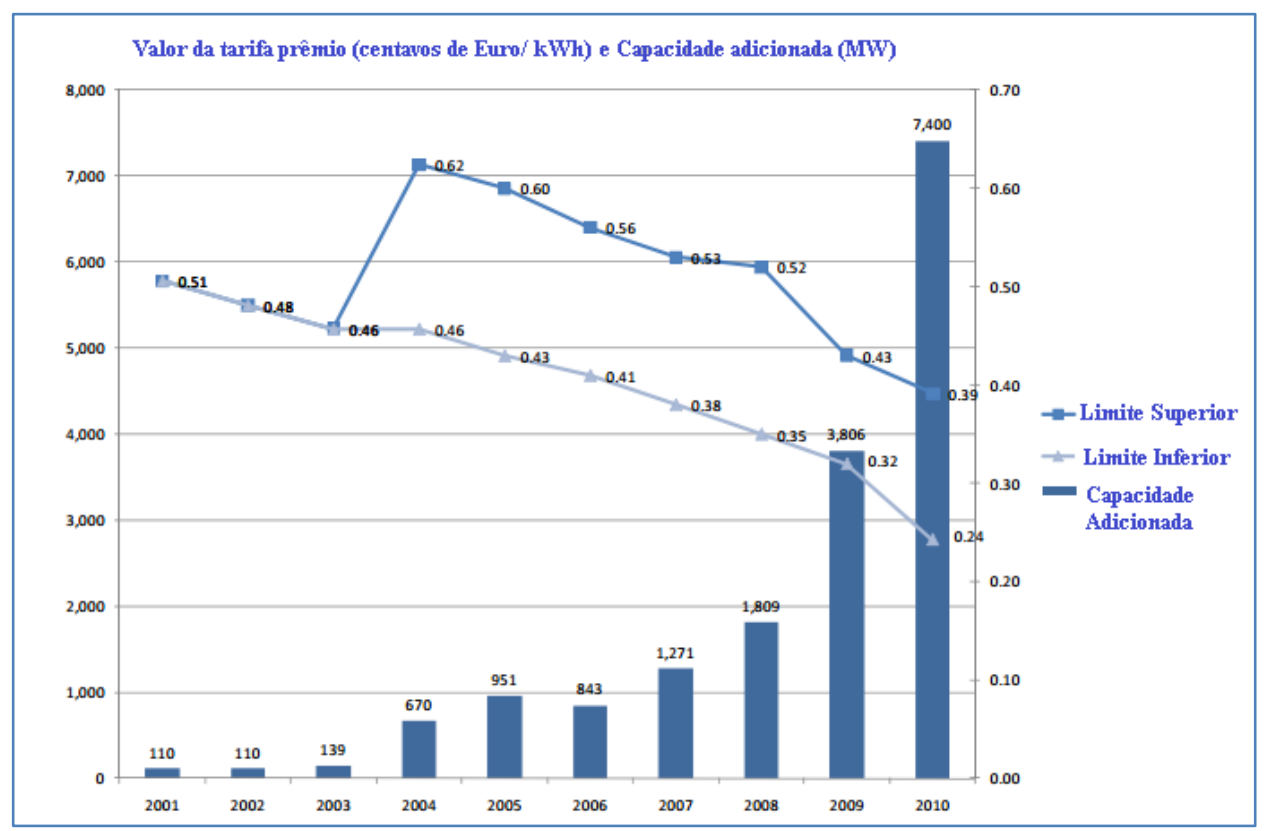

Fonte: Deutsche Bank Group - DB Climate Change Advisors: The German Feed-in-Tariff for PV, 2011 (modificado). Disponível em : < https://www.db.com/cr/en/docs/German_FIT_for_PV.pdf>.

Figura 2.17 Evolução da tarifa prêmio e da capacidade solar fotovoltaica instalada na Alemanha.

O EEG 2014 estabelece novas metas de aumento anual de capacidade (2,5 GWp) e as seguintes metas de participação das fontes de energia renovável no consumo total (BMU, 2014):

- 40 a $45 \%$ de participação até 2025;

- 55 a $60 \%$ de participação até 2035; e

- $80 \%$ de participação até 2050 .

Atualmente, cerca de um terço da eletricidade gerada a partir de novos sistemas é usado no próprio local, uma tendência impulsionada por tarifas prêmio reduzidas nos últimos anos, chegando a valores menores que o preço da eletricidade da rede (REN21, 2014). A Figura 2.18 compara os preços das tarifas prêmio e o preço médio da eletricidade para o setor residencial. Nota-se que em 2011, já houve a chamada paridade tarifária. 


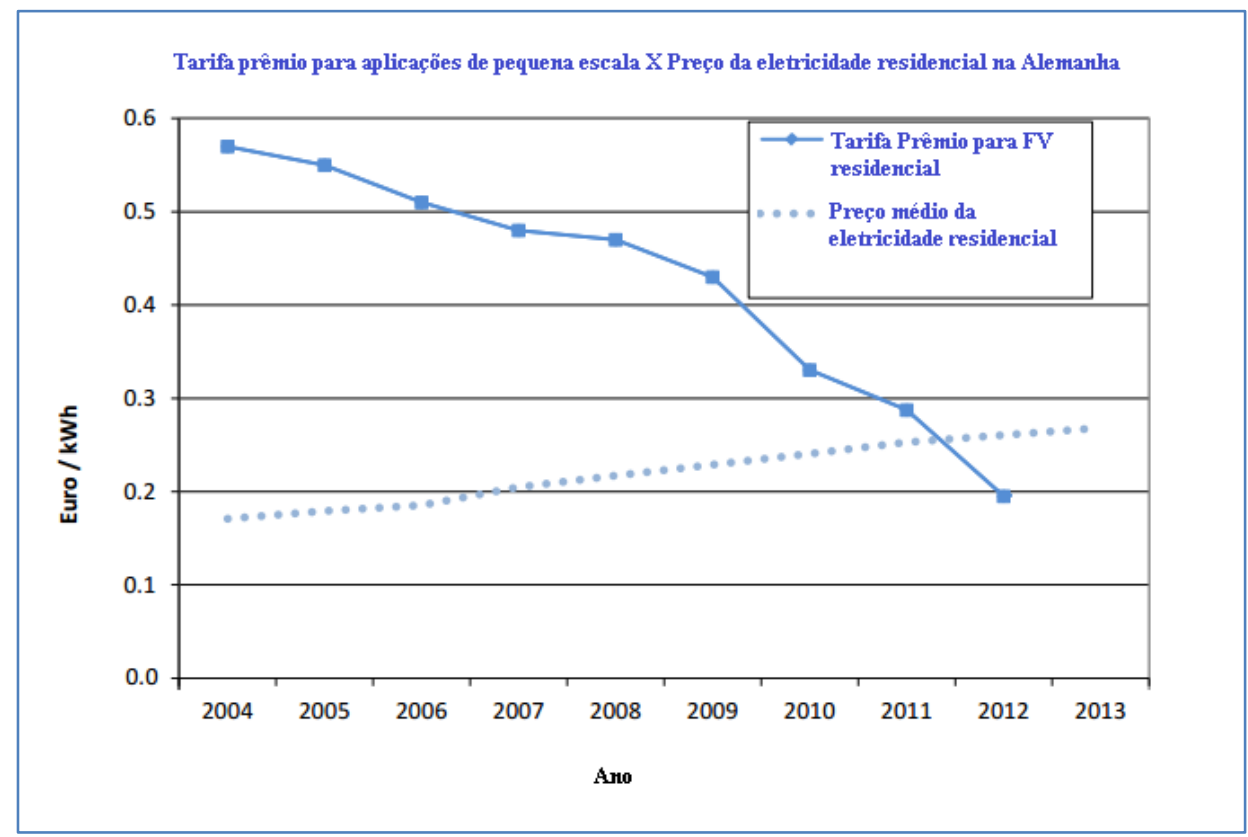

Fonte: Deutsche Bank Group, DB Climate Change Advisors: The German Feed-in-Tariff: Recent Policy Changes, 2012 (modificado).

Figura 2.18 Tarifa prêmio X Preço da eletricidade em aplicações residenciais na Alemanha.

A Alemanha desenvolveu outros mecanismos de incentivos a GDFV, tais como créditos fiscais e empréstimos concedidos pelo banco público KfW-Bankengruppe (IEA-PVPS, 2011). Esses financiamentos são essenciais ao desenvolvimento da tecnologia, já que envolve altos valores de investimento inicial e os riscos de novas tecnologias são altos. A taxa de juros cobrada varia de $3 \%$ a $5 \%$ ao ano (IEA-PVPS, 2014b).

Outro fator importante para o desenvolvimento da GDFV no país foi o investimento em pesquisa e desenvolvimento da tecnologia. Em 2011, o aporte de recursos para pesquisas através do programa lançado pelo Ministério de Meio Ambiente (BMU) e pelo Ministério de Pesquisa (BMBF) foi de 100 milhões de euros.

Uma análise publicada pelo BSW-Solar, a associação da indústria solar alemã, mostra que o preço médio do sistema FV de menos de $10 \mathrm{kWp}$ chegou a cerca de 1.500 euros/kWp no último trimestre de 2013. Isto significa que os preços do sistema foram reduzidos em $66 \%$ nos últimos seis anos. Portanto, os investimentos em instalações fotovoltaicas estão se tornando atraentes mesmo sem o apoio financeiro de uma tarifa prêmio. (IEA-PVPS, 2013). 


\subsubsection{China}

A China anunciou a instalação de 11,3 GW de energia fotovoltaica conectada à rede em 2013, estabelecendo um recorde em termos de novas instalações, superando os 9,3 GW instalados na Itália em 2011. No final de 2013, a China tinha 18,3 GW instalados de energia solar fotovoltaica, o que representa $1,5 \%$ de seu parque gerador (BP, 2014). Esse desempenho está alinhado com as ambições das autoridades chinesas em continuar desenvolvendo o mercado interno FV, chegando a $35 \mathrm{GW}$ até o ano 2015 e $100 \mathrm{GW}$ até 2020 (IEA, 2014). No ano de 2012, essa fonte representava apenas $0,2 \%$ de sua matriz elétrica, conforme a Figura 2.19.

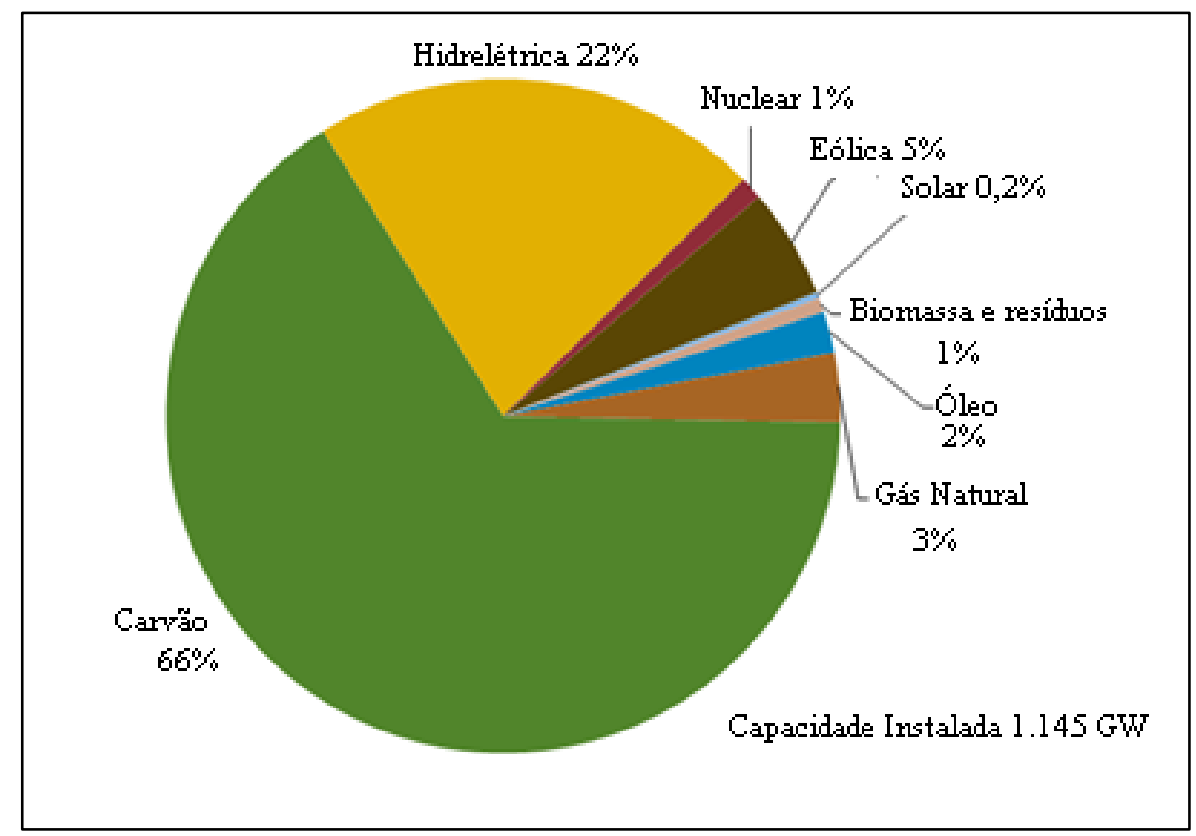

Fonte: IEA-PVPS, 2014a (modificada). Annual report 2013. Report IEA-PVPS T1-20:2014. Disponível em: <www.iea-pvps.org>.

Figura 2.19 Matriz Elétrica Chinesa em 2012.

Vários mecanismos estão incentivando o desenvolvimento da energia FV na China, tanto para aplicações de telhados conectados à rede, como para aplicações isoladas em áreas sem acesso à eletricidade. Em 2012, as seguintes medidas estavam em vigor (IEA-PVPS, 2013):

1) Tarifa prêmio para plantas FV financiadas por um acréscimo na conta de energia elétrica dos consumidores de energia elétrica; 
2) Um programa para incentivar a energia FV em edifícios (o PV Building Project), financiado através de um fundo especial para energia renovável;

3) O programa chamado "Golden Sun Program" que busca desenvolver sistemas FV em edifícios e aplicações não conectadas a rede. A 4 $4^{\mathrm{a}}$ fase do programa começou em 2012 com 1.709 MW em projetos recebendo financiamentos; e

4) Um fundo, diretamente controlado pelo Ministério das Finanças para dar suporte às aplicações distribuídas investe entre 10 a 20 bilhões de CNY (aproximadamente entre 1,6 a 3,1 bilhões de US\$) por ano (IEA-PVPS, 2014b). A partir de novembro de 2012, 2.830 MW foram selecionados para os dois últimos programas de subsídios.

No total, os programas existentes chegavam a 10,5 GW de projetos já instalados ou aprovados para futuras instalações.

Grande parte da capacidade da China está concentrada nas ensolaradas províncias ocidentais, longe dos centros de carga, e são projetos em grande escala. Ainda há um crescente interesse em GDFV e o governo tem como objetivo focar mais no mercado de telhados (REN21, 2014).

A partir de dezembro de 2012, as tarifas prêmio foram ajustadas de acordo com os recursos solares e um subsídio que incentiva o autoconsumo foi introduzido. No caso de autoconsumo, o excedente de energia elétrica pode ser adquirido pelo operador da rede e um bônus pode ser pago em cima do preço da eletricidade. Além disso, espera-se que o ajuste irá substituir progressivamente os programas de subsídios, enquanto aplicações de autoconsumo serão mais incentivadas que os de usinas solares, em um modelo similar ao sistema de compensação brasileiro.

O mercado está principalmente concentrado nos sistemas conectados à rede, com apenas 500 MW de aplicações não conectadas. Plantas de grande escala somam 12,7 GW instalados até 2013, enquanto as aplicações distribuídas participaram com 5,4 GW instalados, representando 28,7\% das instalações no país (IEA-PVPS, 2013). 


\subsubsection{Itália}

A Itália era, até o ano de 2012, o segundo maior mercado de energia solar FV do mundo. No entanto, o ano de 2013 foi marcado pela conclusão do programa "Conto Energia" no país. Este programa consistia basicamente no pagamento de tarifa prêmio. Com sua conclusão, novos empreendimentos não fazem jus ao uso das tarifas prêmio. Este se iniciou no ano de 2005 e foi sendo prorrogado até o ano de 2012, quando em julho foi lançada a quinta fase do programa, estipulando um prazo para seu término. Este prazo foi fixado para 31 dias após a data em que o valor de repasse das tarifas prêmio atingisse 6,7 bilhões de euros por ano. Em Junho de 2013, o programa atingiu o limite de orçamento anual para incentivos nas tarifas de energia fotovoltaica e, portanto, terminou oficialmente um mês depois, a fim de finalizar as plantas em construção (IEA-PVPS, 2013).

Neste cenário de descontinuidade devido ao fim do programa "Conto Energia", a potência total instalada em 2013, 1.461 MW, foi inferior à instalada no ano anterior, 3.646 MW (IEA-PVPS, 2013). É interessante observar que a meta inicial do programa (8 GW de energia solar fotovoltaica até 2020) foi atingida em 2011. Mesmo com o fim da utilização de tarifas prêmio, a Itália ainda é um dois países com maior participação da energia fotovoltaica na geração de eletricidade, como mostra a Figura 2.20.

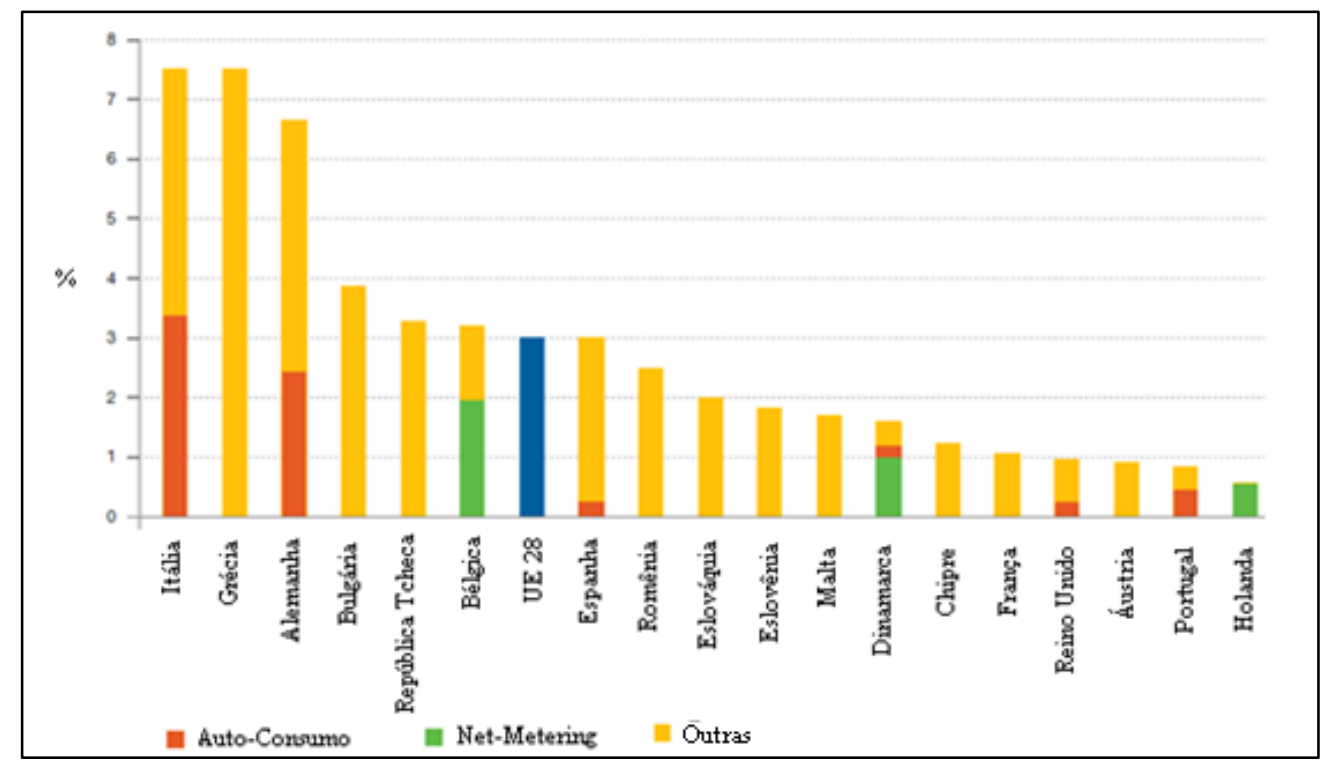

Fonte: EPIA, 2014 (modificado). Global Market Outlook For Photovoltaics 2014-2018. 2014. Disponível em < http://www.epia.org/news/publications/ $>$.

Figura 2.20 Contribuição Solar Fotovoltaica na geração de eletricidade na EU em 2013. 
A capacidade fotovoltaica instalada acumulada na Itália é de 17,6 GW, ou seja, 14\% de sua capacidade total instalada. Em 2013, 7,5\% da eletricidade do país veio de sistemas FV (EPIA, 2014). A geração de energia solar fotovoltaica em 2013 foi de 22.146 GWh, enquanto o consumo total nacional foi de $317.144 \mathrm{GWh}$. A geração FV atingiu o pico de 10,7\% da demanda em setembro de 2013 (IEA- PVPS, 2013).

Além da utilização de tarifas prêmio, o país adotou outras formas de incentivo da energia FV. No ano de 2011, foi instituído um programa de net-billing ${ }^{4}$ denominado Scambio Sul Posto $^{5}$, exclusivamente para instalações menores que $200 \mathrm{kWp}$ (IEA-PVPS, 2014b). Em março de 2013, o país anunciou a redução de 50\% dos impostos sobre o custo das novas instalações FV menores que $20 \mathrm{kWp}$ que adotem o consumo próprio e que tenham custado até $96.000 €$. (IEA-PVPS, 2014b).

Uma linha específica para o financiamento de sistemas FV residenciais ou comerciais, de até $20 \mathrm{kWp}$, torna possível os investimentos para os consumidores. Os valores variam de $5.000 €$ a $70.000 €$ e visam cobrir todo o custo da instalação, incluindo impostos. A taxa de juros é fixa e igual a 6,75\% a.a. e os empréstimos podem ser pagos de 36 a 180 meses (IEA-PVPS, 2014b).

Enquanto a energia fotovoltaica na Itália está se aproximando da competitividade com outras fontes devido aos bons valores de radiação e ao alto custo da eletricidade, um fator importante que atualmente dificulta o desenvolvimento desta tecnologia é representada pela inadequação da rede em algumas regiões do sul da Itália, onde a potência instalada de turbinas eólicas e sistemas FV é quase da mesma ordem de grandeza que o carregamento máximo (IEA- PVPS 2013).

O desenvolvimento de sistemas fotovoltaicos na Itália, agora sem subsídios diretos, acontece por iniciativas sem nenhum custo para o setor público, tais como:

- Regras claras para a venda da eletricidade produzida;

- Simplificação do processo de autorização para instalações fotovoltaicas;

- Foco no autoconsumo da energia produzida; e

\footnotetext{
${ }^{4}$ O Net-billing é um sistema de compensação de energia, no qual as medições de geração e consumo são separadas.

5 Scambio Sul Posto, do italiano, "no ponto de troca".
} 
- Isenção de impostos para a aquisição de equipamentos, bem como para a criação de oportunidades de trabalho (IEA- PVPS, 2013).

\subsubsection{Japão}

O Japão foi o segundo mercado de energia fotovoltaica em 2013, com instalações estimadas em 6,9 GW, chegando a uma capacidade solar fotovoltaica instalada de 13,6 GW, o que representa quase 5\% de sua matriz elétrica (IEA-PVPS, 2014b).

Em 2002, foi publicado a Basic Act on Energy Policy (Energy Policy Law - Lei de Política Energética). As estratégias adotadas para estimular a geração FV foram previstas na "New Energy Innovation Plan" sob a "New National Energy Strategy", ambas de 2006 (IEAPVPS, 2007) e consistiam em subsídios governamentais. Através do Japanese Residential PV System Dissemination Program (também conhecido como 70.000 Roofs Program), foram instalados mais de 250 mil sistemas no período compreendido entre 1994 e 2005 , atingindo um pouco mais de 1,4 GW de potência instalada (IEA, 2010).

A maior parte das instalações no Japão é de aplicações distribuídas, e apenas uma pequena porcentagem são instalações centralizadas conectadas à rede. Em julho de 2012, O Japão iniciou o programa de tarifas prêmio e em 2013 o mercado FV japonês alcançou um crescimento significativo: de 1,7 GW em 2012 para 6,9 GW (IEA - PPVS, 2013). Antes do programa de tarifas prêmio, a política vigente era a de compra do excedente gerado por energia fotovoltaica a valores pré-estipulados.

Em 2013, as tarifas foram estabelecidas em valores menores dos que os de 2012. As tarifas e períodos de compra são estabelecidos da seguinte forma:

a) $37,8 \mathrm{JPY} / \mathrm{kWh}$ (taxas inclusas) para sistemas FV com capacidade de $10 \mathrm{kWp}$ ou mais para um período de 20 anos; e

b) $38 \mathrm{JPY} / \mathrm{kWh}$ (taxas inclusas) para sistemas FV com capacidade abaixo de 10 $\mathrm{kWp}$ para o período de 10 anos.

As tarifas são revisadas anualmente dentro do programa de tarifas prêmio. Em 30 de Novembro de 2013, a capacidade de sistemas FV total aprovada para sistemas abaixo de 
$10 \mathrm{kWp}$ era de $2.155 \mathrm{MWp}$; de $10 \mathrm{kWp}$ a $1 \mathrm{MWp}$ era de $9.524 \mathrm{MWp}$; e acima de $1 \mathrm{MWp}$ 14.546 MWp; totalizando 26.226 MWp (IEA - PPVS, 2013).

O subsídio de apoio à introdução de sistemas fotovoltaicos residenciais somou um orçamento de 119,4 bilhões de JPY (aproximadamente 1 bilhão de US\$) de 2011 até 2013. O único programa de apoio a sistemas fotovoltaicos residenciais a partir de 2014 é o de tarifas prêmio (IEA-PVPS, 2014b). O mercado fotovoltaico japonês era liderado por aplicações residenciais e se deslocou para a estrutura de mercado equilibrada com o crescimento de setores não residencial que consistem em aplicações de energia fotovoltaica para os setores público, comercial e de instalações industriais (IEA - PPVS, 2013).

O Japão tem o objetivo, de acordo com o Action Plan for Achieving a Lowcarbon Society (aprovado em 2008) e o J-Recovery Plan (formulado em 2009) de atingir a capacidade instalada fotovoltaica de $28 \mathrm{GW}$ até 2020 e de $53 \mathrm{GW}$ até 2030 (IEA - PPVS, 2013).

Outras formas de incentivo existem em alguns locais no Japão, como por exemplo, subsídios para o investimento inicial, certificados de energia verde, redução de impostos, financiamentos a juros baixos, entre outros. Apenas em 2013, o Japão gastou 876 bilhões de JPY em pesquisa e desenvolvimento de novas tecnologias (IEA-PVPS, 2014b), o equivalente a 19,5 bilhões de reais ${ }^{6}$.

Em abril de 2014, foi anunciada uma redução no valor das FiT pagas às novas instalações e o programa está agendado para acabar no fim do ano. Contudo, com a aprovação do novo Plano Básico de Energia, que categoriza a energia renovável como uma "fonte de energia nacional, importante e de baixa produção de carbono" e demonstra as intenções do governo em continuar o ritmo acelerado de crescimento, espera-se uma continuação do programa.

\subsubsection{Estados Unidos da América}

De acordo com o Annual Energy Outlook 2013 da EIA, ate 2040 o crescimento de geração de energia elétrica nos Estados Unidos vinda de fonte solar será de 92 bilhões de $\mathrm{kWh}$,

\footnotetext{
${ }^{6}$ Valor calculado em setembro de 2014.
} 
que significa a maior média anual de crescimento comparado às outras fontes: 9,8\% por ano. A Figura 2.21 mostra a projeção de geração de energia elétrica por fontes renováveis nos estados Unidos até 2040, nela observamos que a fonte solar apresenta um dos maiores crescimentos.

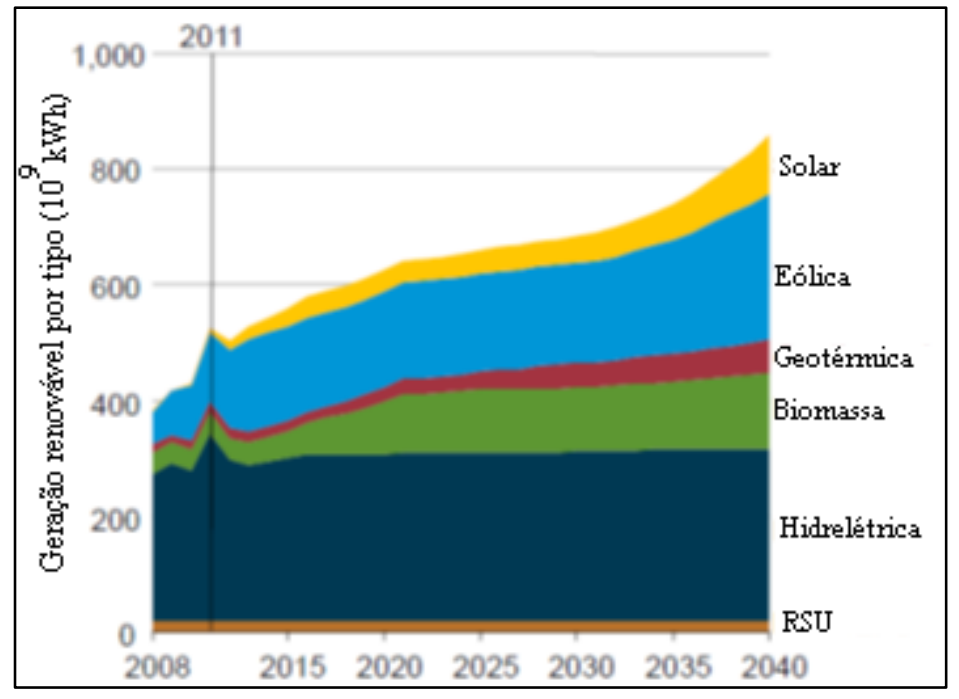

Fonte: EIA, Annual Energy Outlook 2013 (modificado). Disponível em: http://www.eia.gov/forecasts/aeo/.

Figura 2.21 Projeção de geração de energia elétrica por fontes renováveis nos estados Unidos até 2040.

No final de 2012, como pode ser observado na Figura 2.22, a capacidade acumulada de sistemas FV nos Estados Unidos era de aproximadamente 7,3 GW, somado a capacidade instalada em 2013 de 4,8 GW, o país chega ao total de 12,1 GW instalados, cerca de $1 \%$ de sua matriz elétrica (BP, 2014).

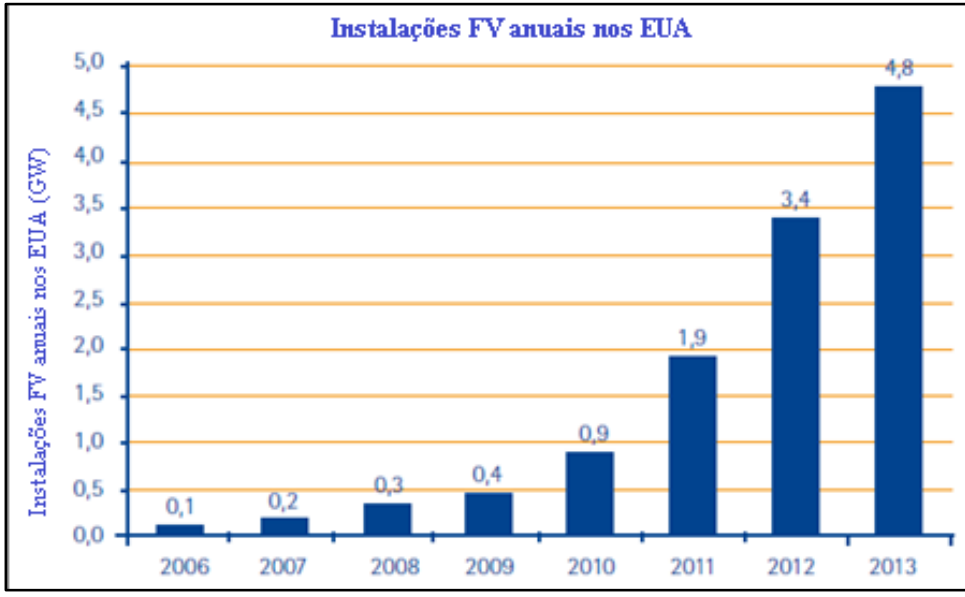

Fonte: EIA, Annual Energy Outlook 2013 (modificado). Disponível em: http://www.eia.gov/forecasts/aeo/.

Figura 2.22 Acréscimo anual de energia solar fotovoltaica nos EUA entre 2006 e 2013. 
Nos EUA, cada estado tem autonomia para definir os programas de incentivo à geração fotovoltaica. No contexto nacional, tem destaque o Renewable Portfolio Standard (RPS), criado em 2002 com a meta de atingir, até 2017, 20\% de energia renovável (AFONSO, 2012). Para o atendimento das metas foram criadas políticas diferenciadas para pequenos e grandes geradores: as contratações de geradores de grande porte são feitas por meio de leilões competitivos, o chamado "Renewable Auction Mechanism” (EPE, 2012).

Foram adotados nos Estados Unidos vários programas de incentivo, alguns para todo o país, como a redução de $30 \%$ dos impostos de renda sobre os gastos com a instalação, outros para estados específicos, como as tarifas prêmio, net-metering (em 43 dos 50 estados), opções específicas de financiamentos, fundos de investimento e RPS (IEA-PVPS, 2014b). Um dos estados que mais se destacam no uso dessa fonte é a Califórnia, por sua boa quantidade de radiação solar em quase todos os meses do ano. Em 2006, foi criado o programa de subsídios California Solar Initiative (CSI), que consiste basicamente em um bônus ao gerador de energia renovável. Eles ganham descontos em dinheiro para cada watt de energia solar instalado em residências, empresas, fazendas, escolas e organizações governamentais e sem fins lucrativos.

Os EUA apoiam a instalação residencial e fabricação de equipamentos para sistemas FV de consumo interno. Os incentivos financeiros para projetos de energia solar são fornecidos pelo governo nacional, governos estaduais e municipais. Historicamente, foram fornecidos principalmente por meio de incentivos fiscais, na forma de investimento, que se aplica a instalações residenciais, comerciais e plantas solares; e depreciação acelerada de 5 anos, que se aplica a todas as aplicações comerciais, plantas FV e instalações de terceiros de propriedade residencial, do governo, ou sem fins lucrativos.

De 2010 a 2013, o mercado americano aumentou suas instalações anuais em aproximadamente $1 \mathrm{GW}$ a mais que o ano anterior; crescendo 0,9 MW em 2010 até 4,8 MW em 2013. Muito desse crescimento veio de usinas solares. A capacidade fotovoltaica continua concentrada em um número pequeno de estados, tais como Califórnia, Arizona e Nova Jersey; cada um com aproximadamente $1 \mathrm{GW}$ de capacidade total instalada. No entanto, esse cenário vem mudando lentamente, já que 15 estados têm atualmente $100 \mathrm{MW}$ ou mais de capacidade FV e 11 estados instalaram mais de $50 \mathrm{MW}$ somente em 2013. Com mais de 3,6 GW de projetos fotovoltaicos, mais de 1MW em construção em fevereiro de 
2014, o número total esperado de instalações em 2014 deve ser ainda maior que os dos anos anteriores. Mesmo alguns programas de incentivo tendo expirado ou sido diminuídos, alguns dos projetos em construção ainda os utilizam. Além disso, os preços dos componentes para os sistemas fotovoltaicos atingiram os valores mais baixos historicamente no mundo.

\subsubsection{Espanha}

A Espanha, assim como a maioria dos países signatários do Protocolo de Kyoto, vem buscando formas de diminuir sua emissão de gases causadores do efeito estufa. Uma forma é trocando sua geração térmica a carvão, gás natural e óleo por fontes limpas de energia como a solar fotovoltaica.

Os principais aspectos da política energética da Espanha estão nos Planos de Energia Renovável. O valor do subsídio e as condições de cada nova planta fotovoltaica estão estipulados em um Decreto Real (DR) que são atualizados quando as metas são atingidas. Foram realizados quatro decretos reais no total (ESPANHA, 2007, 2008, 2010, 2012). Os subsídios consistem basicamente em tarifa prêmio, que variam de acordo com o decreto em que a planta está inserida (MOVILLA, 2013). Na Figura 2.23, observa-se o rápido crescimento na capacidade instalada do país.

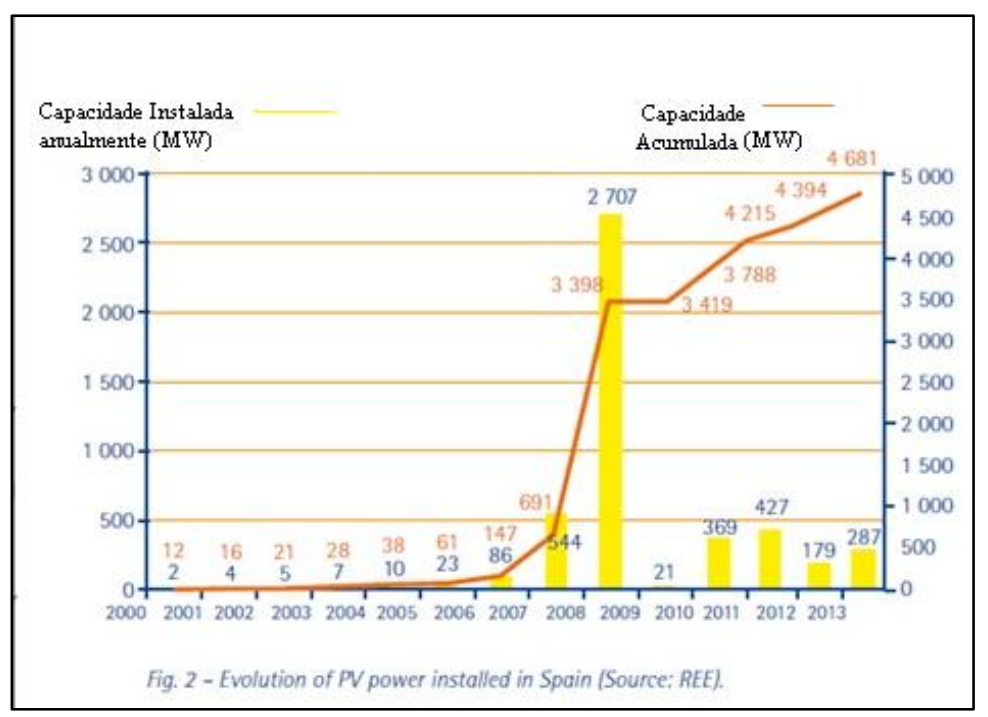

Fonte: IEA-PVPS, 2014a (modificada). Annual report 2013. Report IEA-PVPS T1-20:2014. Disponível em: <www.iea-pvps.org>.

Figura 2.23 Evolução da capacidade solar fotovoltaica instalada na Espanha. 
Depois do rápido crescimento das instalações fotovoltaicas em 2008, devido principalmente a condições tarifárias muito favoráveis, mudanças subsequentes no quadro regulatório reduziram significativamente as instalações anuais em 2009 e 2010. Primeiro, houve a redução tarifa (cerca de 30\%) no final de 2008 e do estabelecimento de um limite de 500 MWp. Em novembro de 2010, outra redução tarifária foi estabelecida para novas instalações FV. Na Figura 2.24, tem-se a evolução das tarifas prêmio para diferentes tipos de plantas no país e nota-se o decréscimo nos valores praticados desde 2007. A comparação é feita com o preço médio pago pela eletricidade em 2013.

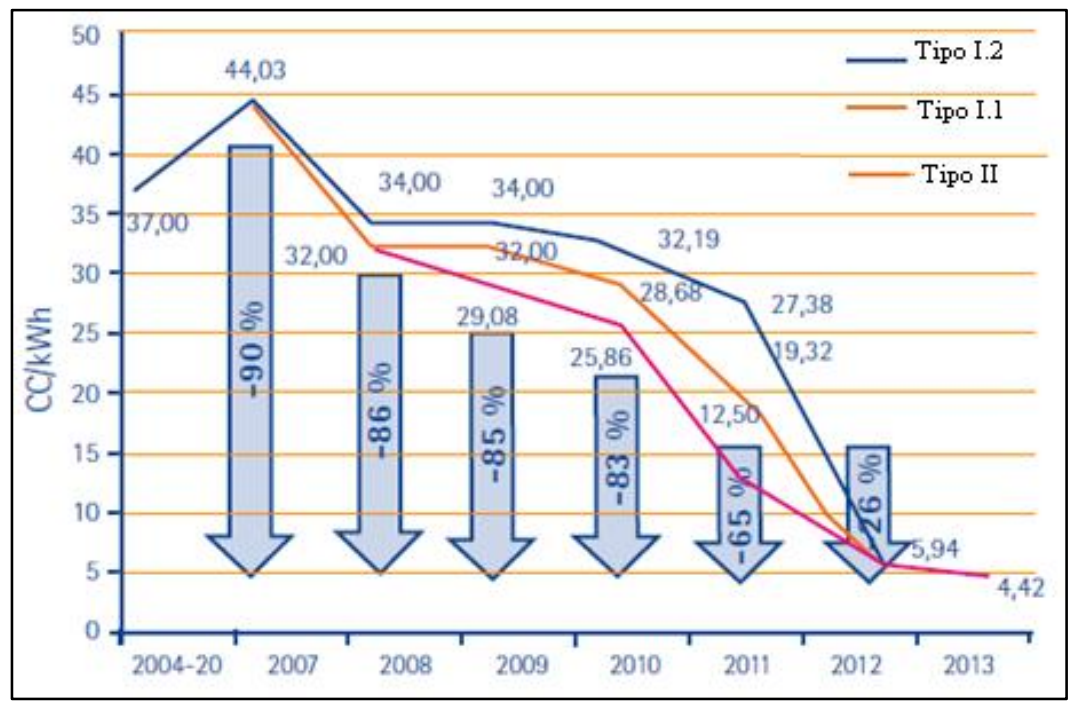

Fonte: IEA-PVPS, 2014a (modificada). Annual report 2013. Report IEA-PVPS T1-20:2014. Disponível em: <www.iea-pvps.org>.

Figura 2.24 Evolução da Tarifa Prêmio para energia fotovoltaica.

A Espanha sustentou sua liderança mundial em capacidade CSP (Concentrating Solar Power), como pode ser observado na Figura 2.25. A capacidade instalada no país cresceu 350 MW em 2013 e aumentou a capacidade operacional em 18\%. A calha parabólica permaneceu a tecnologia dominante na Espanha. 


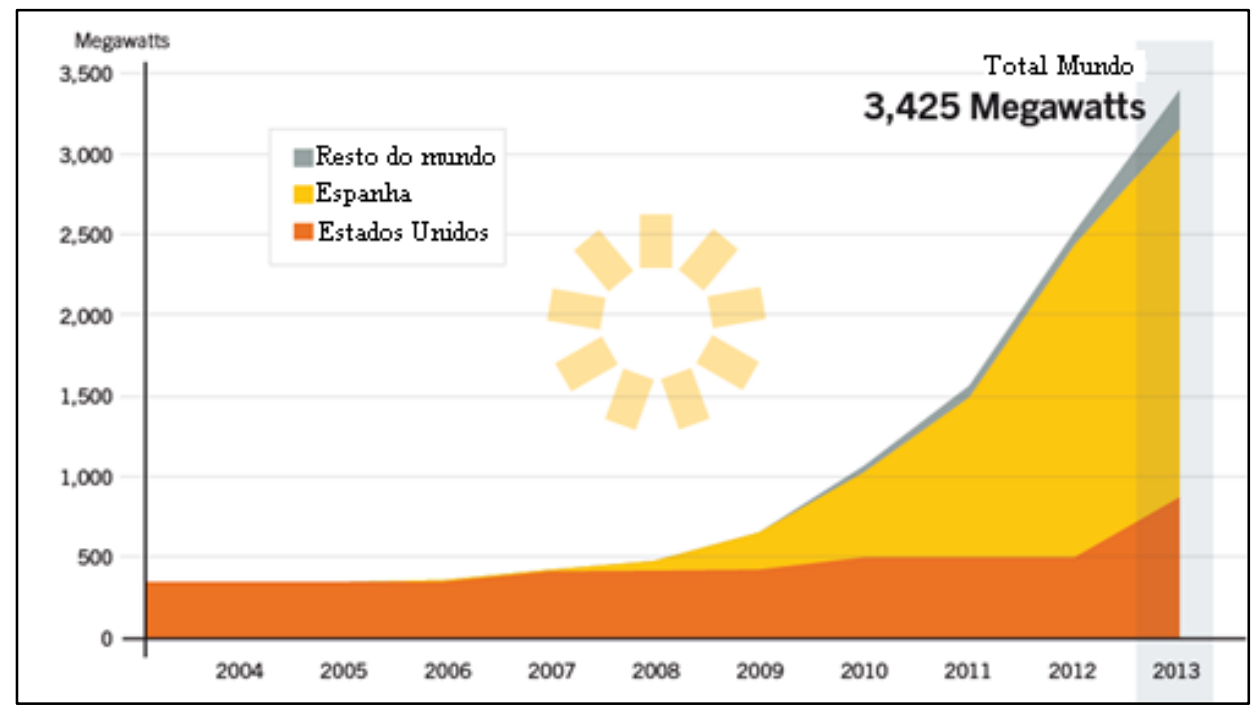

Fonte: REN21, Global Status Report 2014 (modificado). Disponível em: <http://www.ren21.net/REN21Activities/GlobalStatusReport.aspx >. 2014a

Figura 2.25 Capacidade Global de Energia Solar por Concentração.

No entanto, em 2012 foi publicado no Boletín Oficial del Estado (BOE), o real decreto que suspende os incentivos econômicos às fontes renováveis de energia. Na explicação dos motivos para tal suspensão está o atingimento das metas estabelecidas de capacidade instalada no Plan de Energías Renovables 2005-2010 para tecnologia eólica e em particular para as tecnologias solar termoelétrica e solar fotovoltaica. Além disso, é ressaltado o impacto financeiro que os subsídios tiveram e também o decaimento da demanda, devido à crise econômica no país.

\subsubsection{Resumo dos mecanismos utilizados nos países abordados}

Essa seção mostra as várias políticas e meios de incentivar a geração solar fotovoltaica nos principais países do mundo onde essa tecnologia representa parte significativa de suas matrizes elétricas. As modalidades mais utilizadas são as tarifas prêmio (FiT), as cotas de energia, o autoconsumo, a compensação de energia ou financeira, os incentivos fiscais ou financeiros e o investimento em pesquisa e tecnologia. A Tabela 2.5 mostra, resumidamente, as principais políticas adotadas pelos países: 
Tabela 2.5 Políticas adotadas nos países estudados.

\begin{tabular}{|lllll|}
\hline $\begin{array}{l}\text { País/Mecanismos } \\
\text { de Incentivo }\end{array}$ & FIT & Cotas & $\begin{array}{l}\text { Autoconsumo ou } \\
\text { Compensação- }\end{array}$ & $\begin{array}{l}\text { Incentivos Fiscais } \\
\text { e/ou Financeiros }\end{array}$ \\
\hline Alemanha & Sim & Não & Sim & Sim \\
\hline China & Sim & Não & Sim & Sim \\
\hline Itália & Sim & Não & Sim & Sim \\
\hline Japão & Sim & Não & Sim & Sim \\
\hline EUA & Sim & Sim & Sim & Sim \\
\hline Espanha & Não & Não & Sim & Sim \\
\hline
\end{tabular}

\subsection{LEGISLAÇÃO BRASILEIRA PARA ENERGIA SOLAR}

No Brasil, a regulamentação é ponto primordial para viabilizar essa forma de geração e mudanças significativas ocorreram nos últimos anos com ações de governo para o desenvolvimento desta fonte de energia.

\subsubsection{Modelo do setor elétrico e a fonte solar}

A Constituição Brasileira vigente, de 1988, determina que o governo federal seja o responsável pelo fornecimento de energia elétrica, podendo prestar o serviço diretamente ou por meio de concessões, permissões ou autorizações. O Modelo vigente do setor elétrico brasileiro foi implementado em 1995 com a promulgação da lei 9.074 e a principal característica deste modelo foi dada pela lei $\mathrm{n}^{\mathrm{o}} 10.848$, de 15 de março de 2004, que, dentre outras determinações, separou as atividades do setor e determinou os leilões como a forma de aquisição de energia. A seguir, apresenta-se um breve resumo das principais leis que regem esse modelo:

- Lei 8.987/95 - Dispõe sobre o regime de concessão e permissão da prestação de serviços públicos previstos no art. 175 da Constituição Federal (BRASIL, 1995a);

- Lei 9.074/95 - Estabelece normas para outorga e prorrogações das concessões e permissões de serviços públicos e dá outras providências (BRASIL, 1995b); 
- Lei 9.427/96 - Institui a Agência Nacional de Energia Elétrica - ANEEL e disciplina o regime das concessões de serviços públicos de energia elétrica (BRASIL, 1996);

- Lei 9.478/97 - Dispõe sobre a política energética nacional, as atividades relativas ao monopólio do petróleo, institui o Conselho Nacional de Política Energética e a Agência Nacional do Petróleo (BRASIL, 1997);

- Lei 10.438/02 - Dispõe sobre a expansão da oferta de energia elétrica emergencial, recomposição tarifária extraordinária, cria o Programa de Incentivo às Fontes Alternativas de Energia Elétrica (Proinfa), a Conta de Desenvolvimento Energético (CDE), dispõe sobre a universalização do serviço público de energia elétrica (BRASIL, 2002);

- Lei 10.847/04 - Autoriza a criação da Empresa de Pesquisa Energética - EPE (BRASIL, 2004b); e

- Lei 10.848/04 - Dispõe sobre a comercialização de energia elétrica (BRASIL, 2004c);

A lei 10.848/04 determinou que as distribuidoras de energia pertencentes ao Sistema Interligado Nacional (SIN) devem garantir o atendimento à totalidade de seu mercado, devendo, para tanto, adquirir a energia de usinas já existentes e de usinas novas, bem como de fontes alternativas de Energia, no ambiente de Contratação Regulada (ACR). Sendo assim, os leilões são processos licitatórios realizados com o objetivo de contratar a energia elétrica necessária para assegurar o pleno atendimento da demanda futura do mercado das distribuidoras.

No Brasil existem vários tipos de leilão para contratação de energia. Os principais leilões adotados são (CCEE, 2014):

a) Leilão de energia nova: tem como finalidade atender ao aumento de carga das distribuidoras. Neste caso são vendidas e contratadas energia de usinas que ainda serão construídas. Este leilão pode ser de dois tipos: A -5 (usinas que entram em operação comercial em até cinco anos) e A -3 (em até três anos);

b) Leilão de energia existente: foi criado para contratar energia gerada por usinas já construídas e que estejam em operação, cujos investimentos já foram amortizados e, portanto, possuem um custo mais baixo; 
c) Leilão de energia de reserva: criada para elevar a segurança no fornecimento de energia elétrica no Sistema Interligado Nacional (SIN), com energia proveniente de usinas especialmente contratadas para esta finalidade, seja de novos empreendimentos de geração ou de empreendimentos existentes. A energia de reserva é contabilizada e liquidada no mercado de curto prazo operado pela CCEE;

d) Leilão de fontes alternativas: foi instituído com o objetivo de atender ao crescimento do mercado no ambiente regulado e aumentar a participação de fontes renováveis - eólica, biomassa e energia proveniente de Pequenas Centrais Hidrelétricas (PCHs) - na matriz energética brasileira; e

e) Leilões estruturantes: destinam-se à compra de energia proveniente de projetos de geração indicados por resolução do Conselho Nacional de Política Energética (CNPE) e aprovados pelo presidente da República. Tais leilões se referem a empreendimentos que tenham prioridade de licitação e implantação, tendo em vista seu caráter estratégico e o interesse público.

De 2005 a 2013, foram realizados no país 26 leilões para compra de energia: 16 leilões de energia nova, 3 leilões estruturantes, 5 leilões de energia de reserva e 2 leilões de fontes alternativas. A Figura 2.26Figura 2.26 Oferta contratada no Brasil, período 2005 a 2013. mostra a participação de cada fonte na oferta contratada no Brasil, sendo a soma da energia dos leilões e da compra de energia das usinas termonucleares.

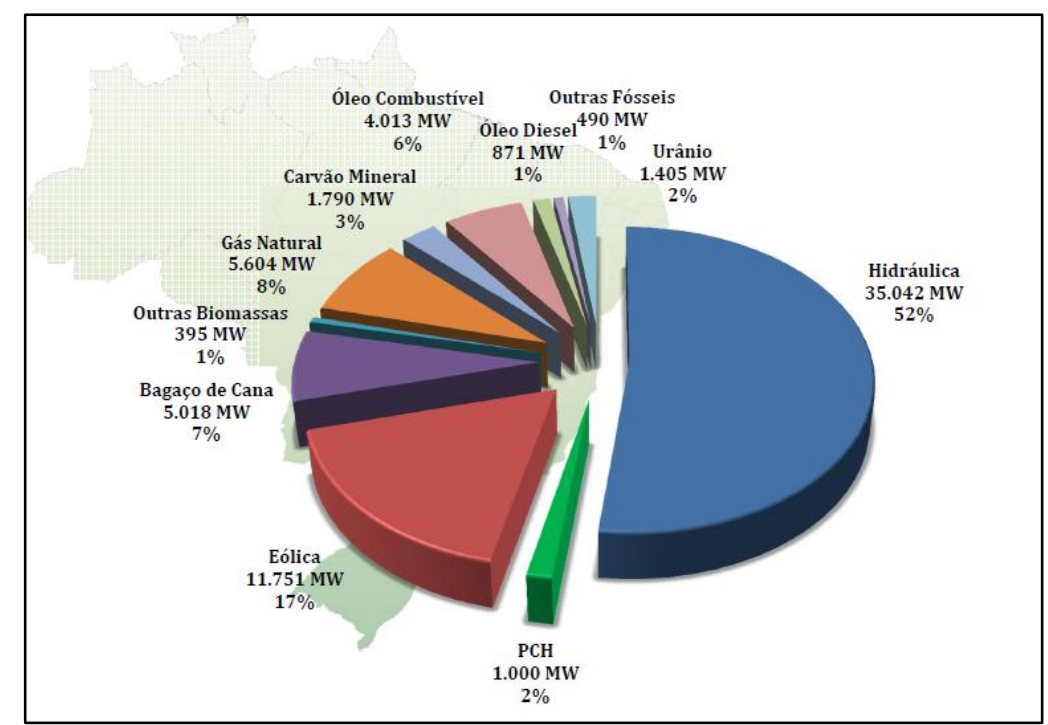

Fonte: EPE, 2014b. Apresentação sobre energia solar da EPE para ABINEE. Disponível em: <http://www.abinee.org.br/informac/arquivos/>.

Figura 2.26 Oferta contratada no Brasil, período 2005 a 2013. 
Nesse contexto de leilões de energia, a fonte solar é uma das diferentes formas de geração que podem ser vendidas nos certames. No leilão de energia nova A-3/2013, que ocorreu em 18 de novembro de 2013, foi possível, pela primeira vez, perceber a participação de projetos de energia solar. Foram inscritos 109 projetos fotovoltaicos, totalizando 2.729 MW de potência instalada, e 10 projetos heliotérmicos (290 MW) (EPE, 2014a). Os projetos solares (fotovoltaicos e termosolares) foram a segunda maior fonte em participação no certame. No entanto, nenhum desses projetos obteve êxito no leilão, já que competiram com outras fontes mais baratas, como a eólica.

O Governo brasileiro promoveu o primeiro leilão específico para fonte solar, o $6^{\circ}$ leilão de energia de reserva, em 31 de outubro de 2014. A licitação incluiu a contratação separada de três tipos de fontes de energia: eólica, solar e de resíduos sólidos (lixo urbano e biogás). Foi a primeira vez que os projetos de geração de fonte solar tiveram um processo de contratação exclusiva. Foram contratados 31 projetos somando $1.048 \mathrm{MWp}$ de capacidade instalada, ou 889,70 MW considerando a energia injetada na rede, de energia solar, a um preço médio de $\mathrm{R} \$ 215,12 / \mathrm{MWh}$, um deságio de 17,9\% em relação ao preço teto estipulado, R\$ 262/MWh. Esse leilão servirá posteriormente neste trabalho para uma avaliação quanto ao melhor mecanismo de incentivo da fonte solar no país.

Iniciativa semelhante fez o estado de Pernambuco ainda em 2013. O estado promoveu a realização de um leilão específico de fonte solar que resultou na contratação de energia de seis projetos, mas um deles foi desclassificado posteriormente. Os empreendimentos idealizados por empresas brasileiras, italianas, alemãs, chinesas e espanholas contrataram 122,82 MW, número que caiu para 92 MW depois da desclassificação de um projeto, a um preço médio de R\$228,63/MWh.

Ainda no âmbito estadual, uma ação específica para energia solar foi criada no Ceará: o Fundo de Incentivo à Energia Solar do Ceará (FIES), com o objetivo de incentivar a instalação e manutenção de usinas destinadas à produção de energia solar, assim como fabricantes de equipamentos solares no território cearense. O FIES utiliza a ferramenta denominada tarifa prêmio, arrecadando recursos provenientes do tesouro estadual, patrocinadores voluntários, indústrias incentivadas pelo FDI (Fundo de Desenvolvimento Industrial do Estado do Ceará) e outras interessadas em utilizar parcialmente energia solar. Como resultado mais significativo, esse fundo promoveu a instalação da usina de Tauá da 
MPX Energia, com capacidade instalada de $1 \mathrm{MW}$, e a construção de uma planta de 10MW, em fase de desenvolvimento, da empresa Kwara.

A geração por fonte solar, bem como por outras fontes renováveis, ainda possui vantagens relacionadas ao mercado livre de energia. O consumidor pode deixar de ser cativo e se tornar livre se tiver demanda mínima de $3 \mathrm{MW}$, mas esse valor é reduzido para $500 \mathrm{~kW}$ se adquirir energia de fontes renováveis.

Na linha mais comumente utilizada no mundo, a geração distribuída, o Brasil já algum tempo tratou sobre o tema. A Lei $n^{\circ} 10.848 / 2004$ (BRASIL, 2004b) traz em seu art. $2^{\circ}, \S$ $8^{\circ}$, que é permitido que a distribuidora adquira parte de sua energia de usinas com geração distribuída (observados limites de contratação e repasse às tarifas dos consumidores finais), por meio de chamadas públicas.

A Agência Nacional de Energia Elétrica (ANEEL) publicou, em 17 de abril de 2012, a Resolução Normativa ${ }^{\circ} 482$ (ANEEL, 2012), que estabelece as condições gerais para o acesso de microgeração e minigeração distribuída aos sistemas de distribuição de energia elétrica e define o sistema de compensação de energia elétrica. Em 11 de dezembro de 2012, a Agência publicou a Resolução Normativa $n^{\circ} 517$, alterando a RN nº482 e o módulo 3 dos Procedimentos de Distribuição - PRODIST.

Com essa nova regulamentação, um novo paradigma surge: o consumidor, pessoa física sem necessariamente conhecimento técnico, pode se tornar um gerador de energia. Não mais apenas grandes empresas especializadas são as responsáveis pelo planejamento da expansão da geração e adequação das redes elétricas da distribuição. Nesse ambiente regulatório, a geração pode ocorrer em qualquer barra do sistema de distribuição, a critério do consumidor. Para essa realidade, novas abordagens de operação e expansão dos sistemas de distribuição são necessárias.

No ano de 2012, além da RN ANEEL n 482, a RN ANEEL nº 481 estipulou desconto nas tarifas de uso do sistema de transmissão e distribuição para os empreendimentos de fonte solar que entrarem em operação comercial até 31/12/2017, sendo 80\% de desconto aplicável aos 10 primeiros anos de operação e 50\% de desconto após o décimo ano. 


\subsubsection{Resolução Normativa ANEEL n ${ }^{\circ}$ 482/2012}

A RN nº482 conceitua microgeração distribuída como central geradora de energia elétrica, com potência instalada menor ou igual a $100 \mathrm{~kW}$ e que utilize fontes com base em energia hidráulica, solar, eólica, biomassa ou cogeração qualificada, conforme regulamentação da ANEEL, conectada na rede de distribuição por meio de instalações de unidades consumidoras; e minigeração distribuída como central geradora de energia elétrica, com potência instalada superior a $100 \mathrm{~kW}$ e menor ou igual a $1 \mathrm{MW}$. A Tabela 2.6 apresenta a classificação das unidades geradoras quanto ao porte.

Tabela 2.6 Tipos de geração fotovoltaica no Brasil

\begin{tabular}{|ll|}
\hline Tipo de Geração Fotovoltaica & Capacidade Instalada \\
\hline Micro & Até $100 \mathrm{~kW}$; usualmente em Baixa Tensão \\
\hline Mini & $\begin{array}{l}\text { De } 100 \mathrm{~kW} \text { a } 1 \mathrm{MW}, \text { usualmente em Média } \\
\text { Tensão }\end{array}$ \\
\hline Pequena & De $1 \mathrm{MW}$ a $30 \mathrm{MW}$ \\
\hline Grande & Maior que $30 \mathrm{MW}$ \\
\hline
\end{tabular}

Fonte: ANEEL, 2012. Resolução Normativa n 482/2012.

O sistema de compensação de energia instituído pela $\mathrm{RN} \mathrm{n}^{\circ} 482 / 2012$, mais conhecido mundialmente como net-metering funciona de forma que a energia ativa injetada por unidade consumidora com microgeração distribuída ou minigeração distribuída é cedida, por meio de empréstimo gratuito, à distribuidora local e posteriormente compensada com o consumo de energia elétrica ativa no mesmo posto tarifário. O consumidor terá até 36 meses após a geração de sua energia para usar tais créditos. Expirado o prazo, ele perderá o direito sobre eles, os quais serão revertidos em prol da modicidade das tarifas de energia elétrica. Há ainda a possibilidade de o consumidor utilizar esses créditos em outra unidade (desde que as duas unidades consumidoras estejam na mesma área de concessão e sejam do mesmo titular).

No artigo $3^{\circ}$ da referida Resolução, estabeleceu-se que cada uma das distribuidoras de energia elétrica no Brasil deveria elaborar uma norma para operacionalizar a instalação da geração distribuída em suas áreas de concessão. As distribuidoras tiveram um prazo de 240 dias para efetuar as alterações e publicar as referidas normas técnicas, padronizando os requisitos para a conexão de consumidores atendidos em baixa tensão $(<1 \mathrm{kV})$ que fizerem a adesão ao sistema de compensação de energia. Essas normas foram subsídio para 
alteração no Módulo 3 dos Procedimentos de Distribuição - PRODIST, que trata do acesso ao sistema de distribuição.

Importante ressaltar que, para unidades consumidoras conectadas em baixa tensão (maioria dos consumidores residenciais), ainda que a energia injetada na rede seja superior ao consumo, será cobrado o valor em reais referente ao custo de disponibilidade, que é o valor em moeda corrente equivalente a: $30 \mathrm{kWh}$ para monofásico, $50 \mathrm{kWh}$ para bifásico e 100 $\mathrm{kWh}$ para trifásico. Dependendo da forma de incidência dos impostos em cada Estado, o consumidor terá ainda que pagar os impostos incidentes sobre o total da energia absorvida da rede e não no consumo líquido e isso será analisado posteriormente neste trabalho.

\subsection{INSTALAÇÕES SOLARES NO BRASIL}

O Brasil conta atualmente com aproximadamente $15 \mathrm{MW}$ em geração fotovoltaica em operação, de acordo com o Banco de Informações da Geração (BIG) da ANEEL. A maior parte das instalações no país ocorre em áreas isoladas.

O programa do Governo Federal "Luz Para Todos", lançado em novembro de 2003 para levar energia elétrica aos moradores de área rural, atingiu, em agosto de 2013, o atendimento a 3.068.333 domicílios rurais, beneficiando mais de 14,9 milhões de pessoas em todo o país. Uma das vertentes desse programa é levar energia elétrica a regiões eletricamente isoladas. Comunidades remotas da Amazônia estão recebendo eletricidade gerada em mini usinas fotovoltaicas e distribuídas por mini redes. Este sistema, por exemplo, vem funcionando, desde 2010, em comunidades do Amazonas nos municípios de Novo Airão, Eirunepé, Beruri, Barcelos, Autazes e Maués. O investimento total é de R\$ 6,6 milhões e estão sendo atendidas 222 residências, beneficiando cerca de 1.110 pessoas. Na Ilha de Marajó, no município Curralinho, no Estado do Pará, as comunidades de Araras Grande Sul, Araras Pequena, Araras Grande Norte e Arara Micro estão recebendo energia elétrica gerada dessas mini usinas. Para os próximos anos há projeção que o número de comunidades isoladas atendidas por sistemas fotovoltaicos continue crescendo.

Dentro do sistema interligado, uma iniciativa interessante é a construção de estádios Solares, tem-se como exemplos: 
- Maracanã Solar;

- Mineirão Solar (Figura 2.27);

- Estádio de Pituaçu em Salvador; e

- Arena Pernambuco em Recife.

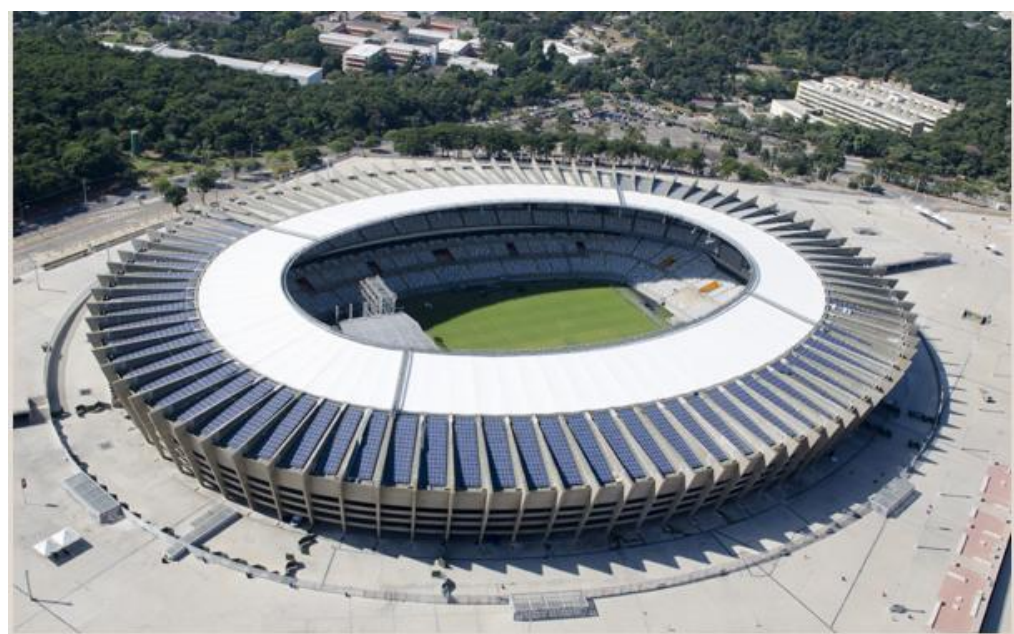

Fonte: AMÉRICA DO SOL, 2014. Disponível em: < http://www.americadosol.org/mineiraosolar/>.

Figura 2.27 Estágio do Mineirão em Minas Gerais com sistema solar.

Muitos desses empreendimentos estão inseridos no contexto de projetos de pesquisa e desenvolvimento (P\&D) fiscalizados pela ANEEL, que são obrigatórios para empresas concessionárias, permissionárias ou autorizadas de distribuição, transmissão e geração de energia elétrica e elas devem aplicar anualmente um percentual mínimo de sua receita operacional líquida. A obrigatoriedade na aplicação dos recursos em $\mathrm{P} \& \mathrm{D}$ está prevista em lei e nos contratos de concessão, cabendo à Agência regulamentar o investimento no programa, acompanhar a execução dos projetos e avaliar seus resultados.

Uma iniciativa interessante promovida pela ANEEL foi a Chamada de Projeto de Pesquisa e Desenvolvimento (P\&D) Estratégico 013/2011 - “Arranjos Técnicos e Comerciais para Inserção da Geração Solar Fotovoltaica na Matriz Energética Brasileira", publicada em agosto de 2011, que recebeu 18 propostas, envolvendo 96 empresas, 62 instituições de ensino e pesquisa e quase 600 pesquisadores. Os projetos aprovados totalizavam um investimento previsto de $\mathrm{R} \$ 396$ milhões em um prazo de três anos. Esse tipo de iniciativa visa ajudar a desenvolver a cadeira produtiva da energia solar, estimular a concorrência, 
reduzir custos e proporcionar a capacitação de instituições de pesquisa, empresas e profissionais, além de transferência de tecnologia (AMÉRICA DO SOL, 2014).

Até 26/03/2014, 295 empreendimentos fotovoltaicos já tinham sido registrados na ANEEL participando do sistema de compensação de energia, totalizando $3.951 \mathrm{~kW}$ em diversos municípios do país, com destaque para o estado de Minas Gerais (ANEEL, 2015).

Porém, nas previsões do governo, em um primeiro momento, a geração distribuída não deve ter grande crescimento, devido à queda nas tarifas causadas pela MP n 579/2012, convertida na Lei $\mathrm{n}^{\circ}$ 12.783/2013 (BRASIL, 2013). Entretanto, mantendo-se a tendência de queda nos custos da tecnologia fotovoltaica e o aumento das tarifas de energia elétrica devido à falta de chuvas, a sua viabilidade deve ser maior nos próximos anos.

O Plano Decenal de Expansão de Energia 2023 realizado pelo MME e EPE estima a evolução para a penetração de sistemas de geração solar fotovoltaica distribuída, como pode ser visto na Figura 2.28

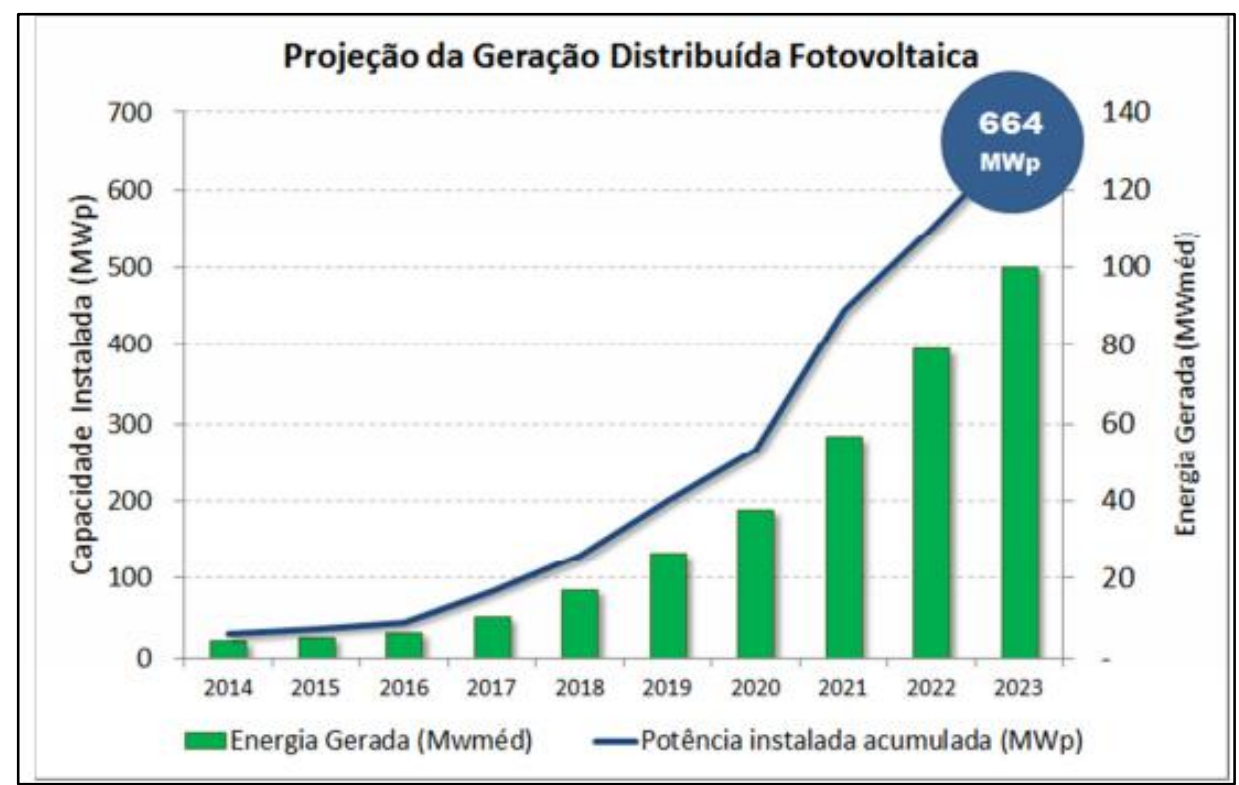

Fonte: MME - Ministério de Minas e Energia, EPE - Empresa de Pesquisa Energética. Plano Decenal de Expansão de Energia 2014 - 2023. Brasília, MME/EPE, 2014. Disponível em <www.mme.gov.br>. Acesso em: maio de 2015.

Figura 2.28 Evolução de capacidade instalada e energia gerada a partir da GDFV. 


\subsection{CONSIDERAÇÕES FINAIS DO CAPÍTULO}

As experiências de outros países, precursores da geração solar fotovoltaica, apontam para o acerto da decisão de investir em uma fonte alternativa ainda pouco explorada. Os mecanismos de suporte à geração solar devem ser diversificados, conforme se pode constatar nos diversos países estudados. Nesse sentido, dentre as modalidades de incentivo utilizadas, destacam-se o pagamento de tarifa prêmio (feed-in tariff), o sistema de cotas, o sistema de compensação (net metering), além dos incentivos financeiros (linhas de crédito a juros menores) e os incentivos fiscais. No capítulo seguinte, esses incentivos serão melhor detalhados e analisados.

No Brasil, duas formas distintas de inserir a fonte solar coexistem: a centralizada e a distribuída. É preciso criar um ambiente favorável aos investimentos, de modo a atrair o maior número de investidores. Nesse sentido, busca-se determinar a forma mais eficiente economicamente de incentivar a geração solar. Para isso, no capítulo 3, é proposta uma metodologia dos incentivos atualmente possíveis no Brasil. 


\section{MECANISMOS DE SUPORTE E METODOLOGIA DE COMPARAÇÃO}

Com todos os desafios que o setor elétrico brasileiro vem enfrentando, surge a necessidade de um modelo de crescimento elétrico alternativo à opção hidrotérmica, a ser implementado com base em energia limpa.

A primeira etapa deste trabalho consistiu em uma revisão bibliográfica do setor elétrico brasileiro e do desenvolvimento da energia solar fotovoltaica em diversos países do mundo. Procedeu-se um levantamento das informações disponíveis sobre a área em estudo, os quais foram: legislação vigente, balanços, planos, programas, apresentações e dados oficiais emitidos pelos órgãos do setor: Empresa de Pesquisa Energética, o Ministério de Minas e Energia, a Agência Nacional de Energia Elétrica e outros entes da administração pública, direta e indireta.

Neste capítulo, foram analisados os mecanismos de suporte mais utilizados por diversos países no mundo para incentivar a geração solar fotovoltaica a fim de se chegar à modalidade de incentivo mais apropriado ao Brasil. Em seguida, é proposto um cenário ideal de desenvolvimento da geração solar distribuída no país, no que tange a regulamentação desse tipo de geração.

Por fim, foi desenvolvido um método que compara os dois mecanismos de incentivo à fonte solar fotovoltaica vigente no Brasil: o leilão específico para a fonte, com valores do preço da energia superiores aos praticados em outras formas de geração; e um subsídio sugerido em financiamento a juros baixos para a geração distribuída.

\subsection{MECANISMOS DE SUPORTE}

Inicialmente, é necessário estudar os incentivos que vêm sendo adotados em outros países para, então, levar essa experiência para a realidade nacional. Na Figura 3.1, vê-se os principais instrumentos que os países com participação significativa de energia solar em suas matrizes utilizam para promover a geração de energia elétrica por meio dessa fonte. 


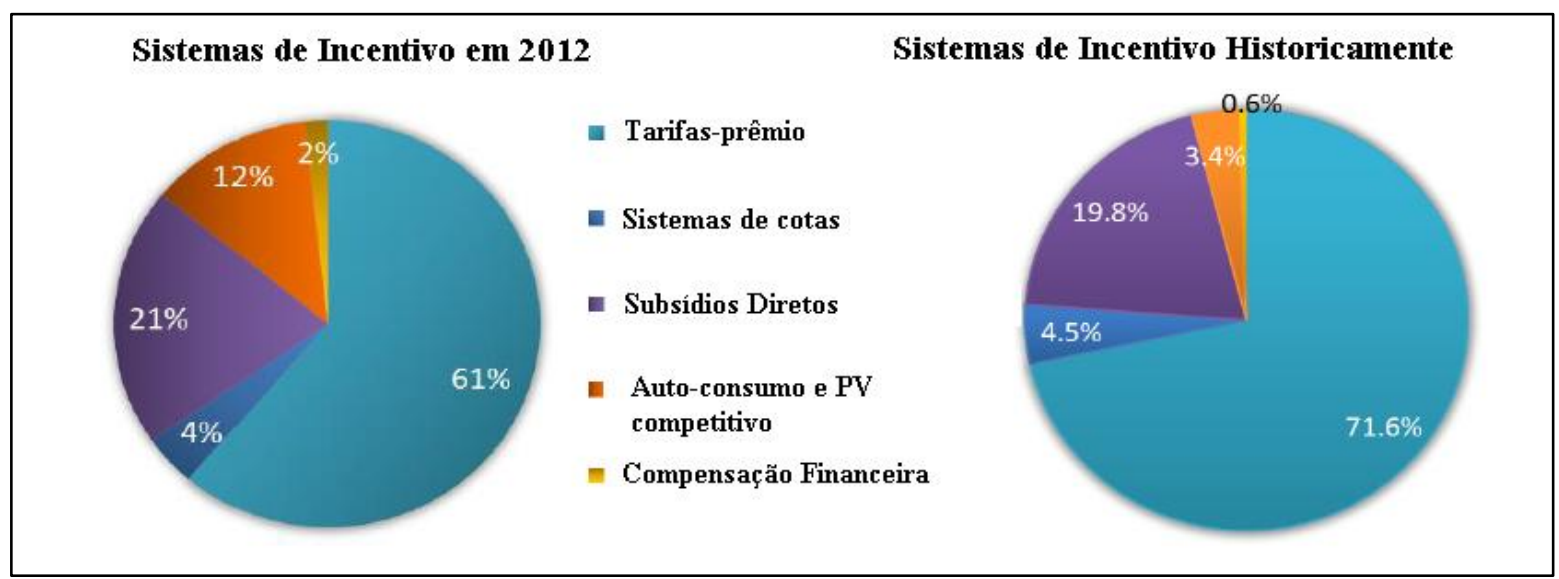

Fonte: IEA-PVPS, 2013 (modificado). Trends 2013 in Photovoltaic Applications. Report IEAPVPS T1-23:2013. Disponível em: <www.iea-pvps.org>. Acesso em: dezembro 2013.

Figura 3.1 Participação dos diferentes sistemas de incentivo a energia FV no mundo.

Entre os principais, estão as tarifas prêmio, o sistema de cotas de energia, os subsídios e linhas de créditos específicas (IEA, 2009). No entanto, os subsídios devem ser criados com cuidado para não estimular a ineficiência. A seguir, apresentam-se esses mecanismos mais detalhadamente.

\subsubsection{Tarifas prêmio}

A tarifa prêmio ou feed-in-tarif(FiT) é um mecanismo bastante simples e foi o mais usado mundialmente para incentivar a geração FV e, até 2009, estava implementada em 63 países pelo mundo (COUTURE \& GAGNON, 2010). Nesse sistema, são oferecidos preços garantidos por certo período de tempo para a energia produzida. Assim, os riscos referentes à instalação dessa tecnologia são praticamente anulados, o que incentiva o investimento. É claro que esse é um tipo de subsídio, e, portanto deve ser estabelecido com cautela. Podem existir valores diferenciados de acordo com o tipo da tecnologia, o tamanho da instalação, o local e outras características desejáveis a cada sistema elétrico.

De acordo com a Comissão Europeia no documento "The support of electricity from renewable energy sources" de 2008, "um regime de tarifas prêmio bem ajustadas são normalmente a forma mais eficiente e eficaz de promover eletricidade advinda de fonte renovável" (EU, 2008). 
O custo da tarifa prêmio pode ser pago pelos contribuintes, por meio de impostos, que é o caso mais comum na Europa, ou por meio de um aumento na conta de eletricidade. A maioria dos países não estabeleceu um teto nos gastos com a tarifa prêmio, o que gerou um rápido desenvolvimento na Alemanha, Itália, Espanha e vários outros países (IEA-PVPS, 2014b). A explosão de mercado ocorrida em alguns países se deu devido à discrepância entre o custo das instalações de geração FV e os valores das tarifas prêmio. Os valores de venda da energia não se adaptaram tão rapidamente ao declínio dos custos de novas instalações, propiciando um ambiente de investimentos de alta rentabilidade e provocando um crescimento desenfreado. Essas explosões de mercado foram observadas na Espanha em 2008 e na Itália em 2011, por exemplo (IEA-PVPS, 2014a).

Mais recentemente, alguns países adotaram tarifas prêmio que variam com o tempo, mas sempre de forma programada, para que haja incentivo à eficiência e as tecnologias tenham que buscar serem cada vez mais competitivas, além de controlar a rentabilidade de novas instalações, propiciando um melhor controle do mercado e evitando explosões repentinas.

Este sistema de remuneração pode medir o total de $\mathrm{kWh}$ produzido, incluindo o consumo (FIT bruto), ou o kWh líquido. FIT bruto implica que toda a energia produzida pelo sistema fotovoltaico é remunerada e que a energia consumida pelo sistema (por exemplo, a energia usada por uma casa com um sistema fotovoltaico) é comprada da rede elétrica no preço da eletricidade. Já na medição líquido, é garantida uma remuneração para somente o líquido de energia injetada na rede elétrica (a energia produzida por FV menos a energia consumida pelo sistema) (SARASA-MAESTRO et al., 2013).

Em geral, o mecanismo de tarifas prêmio continua a ser o mais amplamente adotado mecanismo de suporte à geração FV. A Figura 3.1 apresenta um comparativo entre a utilização desse mecanismo com os demais.

\subsubsection{Cotas de energia}

No sistema de cota de energia, o governo requer que geradores, transmissores, distribuidores e/ou consumidores mantenham certa cota de energia advinda dessas fontes incentivadas no seu portfólio. $\mathrm{O}$ preço é regulado pelos próprios agentes envolvidos. $\mathrm{O}$ sistema de quotas pode ser empregado para estimular a geração de energia em sistemas 
conectados à rede elétrica da distribuidora de energia (grid-connected) ou isolados (offgrid). Há duas formas desse sistema funcionar: o RPS (Renewable Portfolio Standards) e o sistema de licitações.

No RPS, o Governo estabelece quotas de energia renovável e a remuneração do produtor dá-se na forma de créditos pela energia renovável produzida, os quais podem ser comercializados ou vendidos no mercado (conhecidos como green certificates ${ }^{7}$ ). Alguns países que utilizam esse sistema são Estados Unidos, Bélgica, Polônia, Reino Unido e Romênia. No sistema de licitações, o Governo estabelece, através de editais, a quota e também o preço máximo da energia renovável a ser gerada.

Um sistema similar já acontece no Brasil com o sistema de cotas da energia da hidrelétrica de Itaipu, no qual empresas distribuidoras localizadas nas regiões Sul, Sudeste e CentroOeste do Brasil, por imposição legal, pagam uma quota-parte dos custos referentes à energia elétrica produzida por Itaipu e destinada ao País.

\subsubsection{Desconto em impostos e incentivos de investimentos}

A geração FV é uma forma de geração com baixos custos de manutenção e que não possui custos com combustíveis, diferente da maior parte dos tipos de geração de energia elétrica. Contudo, o custo inicial é bastante elevado e representa um obstáculo para que o investimento se torne rentável. Sendo assim, alguns países adotaram ou adotam políticas que permitiram a redução desse custo inicial, tornando o investimento atrativo. Uma barreira ao desenvolvimento da indústria fotovoltaica são os custos dos tributos e impostos, além do custo do capital necessário para uma nova instalação. Uma série de medidas é utilizada para facilitar o acesso ao crédito e reduzir os impostos de novas instalações, funcionando como um suporte ao investimento.

A Redução de Impostos pode ser considerada um mecanismo de suporte com o mesmo intuito de subsídios de capital direto, pois seu objetivo também é reduzir o custo inicial de uma nova instalação. Isenção ou redução de tributos fiscais, em particular, sobre o investimento, sobre a produção de energia e sobre o mercado de bens e capital que são

\footnotetext{
${ }^{7}$ Green Certificates podem ser entendidos como algo equivalente a créditos de carbono.
} 
aplicáveis para a compra (ou produção) de tecnologias de energias renováveis. Esse mecanismo depende dos interesses e metas do governo de cada país e é influenciado pelo ambiente político e econômico.

Há também a possibilidade de deduções no imposto de renda, o que seria capaz de desempenhar importante papel na disseminação da tecnologia fotovoltaica associada à geração distribuída. Dessa maneira, despesas em energia solar, que podem incluir, além do sistema, os custos do trabalho, preparação e instalação do sistema original, poderiam ser abatidos dos custos do imposto de renda. Estudo realizado pela EPE sugere que este tipo de incentivo é capaz de impactar significativamente o custo nivelado de geração, reduzindo-o em aproximadamente 23\% (EPE, 2012). O custo nivelado corresponde, em princípio, ao valor mínimo da tarifa de fornecimento de energia para o consumidor considerar viável, em termos econômicos, seu investimento na geração fotovoltaica.

Além desses, a disponibilidade de financiamento para o desenvolvimento de energias renováveis, para estimular a pesquisa, para a aquisição e produção dessas tecnologias e para a alocação de capital necessário na implantação de projetos de geração de energia são formas de incentivos financeiros. Muitos países criaram linhas de financiamento ou programas de empréstimos em conjunto com as metas de inserção, como, por exemplo, a Alemanha através do "Solarstrom Erzeugen - Solar Power Generation".

A viabilização para pessoas com menor poder aquisitivo se tornarem produtores de energia gerada através de fontes renováveis só é possível se houver a liberação de uma linha de crédito específica para esse propósito, a qual deve ter por característica a concessão de empréstimos a juros baixos. O Brasil possui a maior taxa de juros reais do mundo, segundo pesquisas recentes, o que dificulta sobremaneira o investimento por meio de empréstimos.

Já existem algumas opções para financiar a compra e instalação de micro ou minigerador FV no país. As principais linhas de financiamento oferecidas por bancos públicos brasileiros são divididas em linhas para pessoa física e pessoa jurídica.

Para pessoas físicas, o consumidor residencial, há linhas de crédito aplicáveis no Banco do Brasil, a linha BB Crédito Material de Construção e na Caixa Econômica Federal (CEF), linha Construcard Caixa, ambas linhas criadas para crédito de material de construção. A 
linha do Banco do Brasil possui taxa de juros que variam entre $1,61 \%$ a 2,1\% ao mês, mais IOF e o prazo é no máximo 60 meses. A linha da CEF possui taxa entre 1,5\% e 1,75\% +TR, com prazo máximo de 96 meses e há um limite na prestação de 30\% da renda bruta do solicitante (AMÉRICA DO SOL, 2014).

Para pessoas jurídicas, há linhas de crédito aplicáveis no Banco do Nordeste do Brasil, a linha Programa de Financiamento à Sustentabilidade Ambiental (FNE Verde) e no Banco Nacional de Desenvolvimento Econômico e Social - BNDES, as linhas Financiamento de empreendimentos (Finem) e o Fundo Clima. A linha do Banco do Nordeste se aplica a produtores e empresas rurais, industriais, agroindustriais, comerciais e de prestação de serviços, cooperativas e associações legalmente constituídas estabelecidas na região Nordeste do país. A taxa de juros fica entre 3,53\% e 4,12\% ao ano, com prazos de até 12 anos para amortização. No BNDES, os empréstimos pelo Finem são de no mínimo R \$10 milhões, com taxa de juros de 5\% ao ano, mais outras taxas como renumeração básica do BNDES e taxa de risco de crédito (AMÉRICA DO SOL, 2014). O Fundo Clima apresenta condições ainda mais favoráveis, como pode ser observado na Tabela 3.1.

Foi criada uma linha do BNDES específica para usinas de geração de energia elétrica a partir da fonte solar fotovoltaica vencedoras em leilões de energia realizados em 2014, no âmbito do Ambiente de Contratação Regulada (ACR). As condições financeiras são mostradas na Tabela 3.1.

Tabela 3.1 Financiamento BNDES para fonte solar.

\begin{tabular}{|lcc|}
\hline Parcelas & Condições do Fundo Clima & $\begin{array}{c}\text { Condições do } \\
\text { BNDES Finem }\end{array}$ \\
\hline Custo financeiro & $0,1 \%$ a.a. & TJLP \\
\hline $\begin{array}{l}\text { Remuneração } \\
\text { básica do BNDES }\end{array}$ & $0,9 \%$ a.a. & $1,0 \%$ a.a. \\
\hline Taxa de intermediação financeira & $0,5 \%$ a.a. & $0,5 \%$ a.a. \\
\hline Taxa de risco de crédito & Entre $0,4 \%$ a.a. e $2,87 \%$ a.a., conforme o risco de crédito \\
\hline Prazo & Até 12 anos & Até 16 anos
\end{tabular}

Fonte: BNDES. Disponível em:

<http://www.bndes.gov.br/SiteBNDES/bndes/bndes_pt/Areas_de_Atuacao/Infraestrutura/Energia_ Eletrica/Leilao_Energia/energia_solar_2014.html >. 
O apoio financeiro aos empreendimentos de geração é obtido pelo somatório das parcelas de recursos do Fundo Clima, até $15 \%$ do valor do módulo ou do sistema fotovoltaico multiplicado pelo "Fator N"; recursos do produto BNDES Finem, até $65 \%$ do valor do módulo ou do sistema fotovoltaico multiplicado pelo "Fator N"; e recursos do produto BNDES Finem, até $80 \%$ do valor dos demais itens financiáveis. O valor do "Fator N" é determinado pela quantidade de componentes fabricados e/ou processos produtivos realizados no Brasil, conforme a metodologia para credenciamento de equipamentos e sistemas fotovoltaicos, divulgada pelo BNDES. Quanto maior a quantidade de componentes fabricados ou processos produtivos realizados no Brasil, maior será a participação do BNDES no financiamento. O valor mínimo do "Fator N" é de 60\%, correspondente à fabricação das molduras no Brasil e à montagem nacional dos módulos.

A metodologia deixa de considerar a apuração do índice de nacionalização, tradicionalmente calculado com base no peso e no valor do equipamento, como critério de credenciamento, e exige a nacionalização progressiva de componentes e processos específicos ao longo do período de implementação do plano. Com a nova metodologia, a participação máxima do BNDES no apoio aos empreendimentos fotovoltaicos crescerá proporcionalmente ao número de processos industriais e componentes incorporados no País.

Essa nova metodologia permitirá ao Brasil o desenvolvimento de uma cadeia industrial para fabricação de componentes fotovoltaicos, atualmente inexistente. Outros benefícios são o incentivo à fabricação de componentes e equipamentos de alto teor tecnológico no País e a atração de novos investimentos nacionais e estrangeiros em território brasileiro para o fornecimento de insumos e componentes em qualquer etapa do processo produtivo.

\subsubsection{Compensação de energia elétrica}

Esses esquemas são comumente chamados de consumo próprio, compensação de energia ou net-metering. Eles permitem que a energia gerada localmente seja utilizada, de forma a abater o valor da conta de energia paga pelo dono da instalação, no local da geração, ou até mesmo em outra propriedade do mesmo consumidor. 
Os sistemas tradicionais de consumo próprio assumem que, para ser compensada, a energia produzida deve ser consumida em um intervalo de até quinze minutos. O mecanismo de apoio denominado net-metering permite que a compensação ocorra durante períodos mais longos, variando de um mês a vários anos. Assume-se que ao injetar energia elétrica ativa na rede, o produtor está emprestando a energia e que posteriormente poderá utilizá-la.

A competitividade nesse modelo deve ser analisada com base nos valores da tarifa paga pelo consumidor à concessionária. Para as aplicações nas residências e no comércio, tipicamente referidas à baixa tensão e fisicamente distribuídas na rede, o custo corresponde, em princípio, ao valor mínimo que deve ter a tarifa de fornecimento de energia para considerar viável, em termos econômicos, seu investimento na geração fotovoltaica. Esse mecanismo vigora atualmente no Brasil, desde a publicação da RN ANEEL nº482/2012, conforme explicado na seção 2.6.1.1.

\subsubsection{Leilão}

Um mecanismo muito comum no Brasil e que já foi utilizado por outros países é o leilão de energia advinda da energia solar. O governo leiloa uma cota de energia dessa fonte e os projetos com menor custo ganham o leilão, tendo um prazo pré-estipulado para colocar os empreendimentos em operação.

Os leilões específicos para energia solar podem ser vistos como uma combinação das tarifas prêmio e das cotas de energia, pois o preço é fixado em valores mais elevados dos que os praticados habitualmente e uma quantidade estipulada dessa fonte é contratada. $\mathrm{O}$ primeiro leilão deste tipo ocorreu no Brasil em outubro de 2014.

\subsubsection{A evolução dos incentivos}

Devido à queda de preços dos sistemas fotovoltaicos nos últimos anos e também circunstâncias econômicas nos países europeus, muitas mudanças vêm ocorrendo nos incentivos. A principal característica que pode ser extraída da evolução das políticas é a diminuição do apoio financeiro, parando ou diminuindo a utilização de tarifa prêmio. Consequentemente, vários países da Europa tomaram medidas que indiretamente diminuíram o ritmo do desenvolvimento FV. 
Fora da Europa, vários países adotaram sistemas de tarifas prêmio, principalmente na Ásia: China e Japão implementaram este regime de apoio financeiro, o que desenvolveu o mercado rapidamente. Países que adotam sistemas de cotas estão diminuindo, mas alguns países ainda os utilizam, dentre eles Coréia do Sul, Austrália e Bélgica.

O que se verifica no contexto global é que vários países já estão apoiando a tecnologia através de uma combinação de incentivos, tais como compensação financeira, autoconsumo, cotas de energia, venda a preços competitivos, além de descontos fiscais ou incentivos financeiros. A Figura 3.2 apresenta um panorama atual das politicas utilizadas para incentivar a energia FV.

A ideia de que os produtores de energia FV poderiam ser considerados como autoprodutores está evoluindo rapidamente e políticas estão sendo adaptados em vários países. Políticas de compensação de energia estão sendo consideradas em alguns países, como o México (essas políticas têm apoiado anteriormente o desenvolvimento do mercado nos EUA, Dinamarca, Holanda e, parcialmente, na Bélgica), mas as discussões sobre o impacto nas empresas de serviços públicos e gestão da rede começaram em 2013. Nesse sentido, as políticas de autoconsumo foram adotadas ou estão em discussão na Espanha, França, Alemanha, Suíça e em vários outros países.

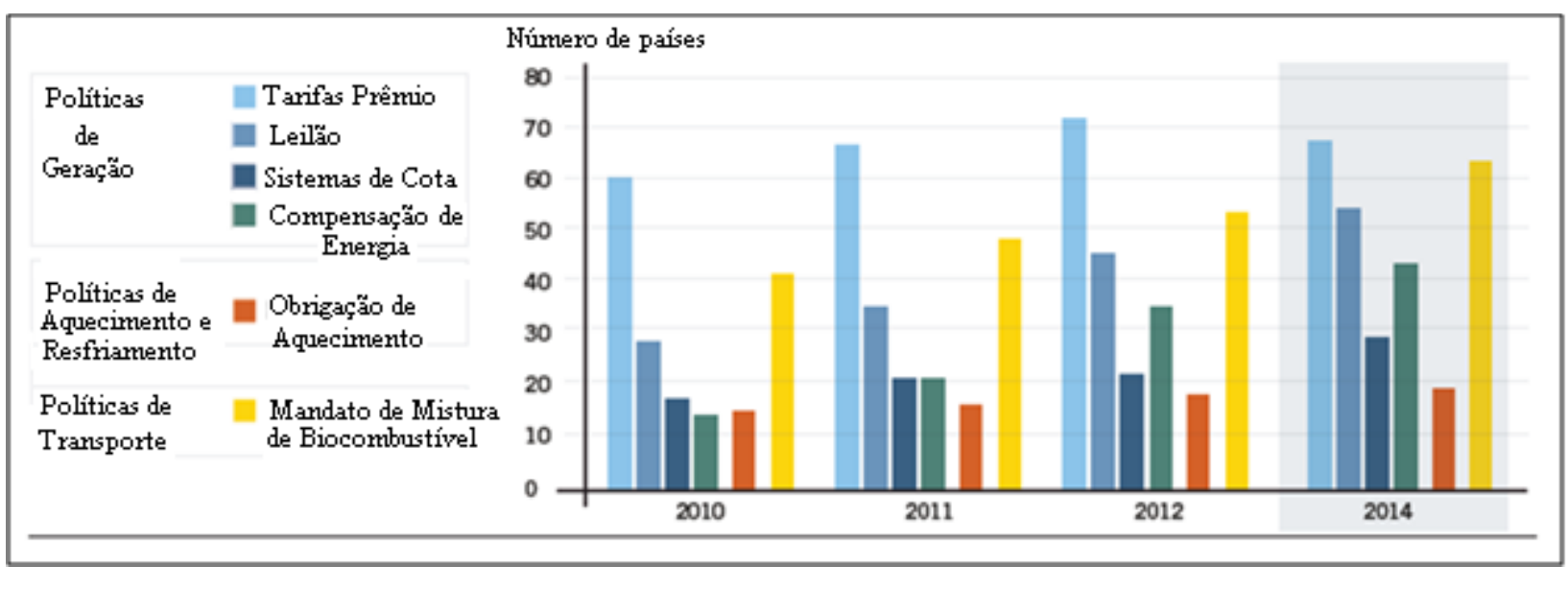

Fonte: REN21, Global Status Report 2014 (modificado). Disponível em: <http://www.ren21.net/REN21Activities/GlobalStatusReport.aspx >. 2014a

Figura 3.2 Número de Países com políticas para energia renovável, por tipo. 


\subsection{CENÁRIO IDEAL DA REGULAMENTAÇÃO DA GD}

Em pouco tempo, o Brasil teve avanços significativos para a inserção da geração fotovoltaica distribuída no país. As normas das distribuidoras em consonância com a RN ANEEL n ${ }^{\circ}$ 482/2012 e as alterações nos Procedimentos de Distribuição (PRODIST) ajudaram a normatizar o tema, possibilitando que o país aumente a inserção desses empreendimentos.

$\mathrm{Na}$ seção 2.6, foi apresentada a regulamentação atual vigente para a GD no Brasil. Apresenta-se a seguir o cenário regulatório ideal para o tema no Brasil.

\subsubsection{Cenário ideal}

\subsubsection{Sob a ótica da concessionária de distribuição}

\subsection{Prestação do serviço Público de energia elétrica}

Segundo o artigo $6^{\circ}$ da Lei 8.989/96, serviço público adequado é aquele que satisfaz as condições de regularidade, continuidade, eficiência, segurança, atualidade, generalidade, cortesia na sua prestação e modicidade das tarifas. As distribuidoras de energia elétrica são concessionárias de serviço público e devem, portanto, nortear todas as suas ações nesses princípios definidos em lei.

Pelo princípio de generalidade, todos os consumidores têm o direito de instalar GDFV em suas residências ou empresas. Assim, as concessionárias devem ter suas redes preparadas ou, no mínimo, estudadas para receber essa GD em qualquer ponto de sua área de concessão.

Considerando o princípio de atualidade, as distribuidoras devem manter sua rede elétrica sempre atual e para tal, fazer investimento em modernização de seus ativos. Ao fazer essas alterações, a concessionária deve considerar a possibilidade de que qualquer um de seus consumidores possa aderir à GD, adequando-se para receber esses potenciais geradores. Ainda nesse sentido, é importante considerar a utilização de smart grids, já que estes criam 
um ambiente em que a GD terá um papel ainda mais relevante na melhoria da qualidade da energia e da eficiência energética (SHAYANI, 2010).

Por fim, o princípio da modicidade tarifaria impõe um limite aos custos de adequação da rede advindos da conexão dos novos geradores, para que não representem um aumento tarifário significativo para os demais consumidores da área de concessão. Deve-se ressaltar que, dentro dos custos módicos, os reforços na rede de distribuição devem permitir que a inserção de geração nos ramais de distribuição não acarrete problemas de descontinuidade no serviço ou perda de segurança na rede.

\subsection{Operação}

A GD impõe um aumento na complexidade de operação do sistema, posto que mais geradores existem em uma mesma área e, principalmente, que a distribuidora não mais é a única que fornece energia, existindo, portanto, um fluxo bidirecional de energia. É clara, então, a necessidade de uma entidade que faça o controle da operação do sistema de geração distribuída, em um modelo similar ao existente no Sistema Interligado Nacional (SIN), no qual o Operador Nacional do Sistema (ONS) controla o despacho e é responsável pela integridade da rede.

Nesse sentido, o módulo 4 do PRODIST cria a figura do Centro de Despacho. Esta entidade é constituída para a coordenação da operação de um agrupamento de centrais de geração distribuída, sendo facultado às distribuidoras o compartilhamento das instalações físicas dos seus Centros de Operação com os Centros de Despacho.

\subsubsection{2. $\quad$ Sob a ótica do consumidor}

\subsection{Viabilidade econômica}

Embora o Brasil seja um país que busca manter sua matriz limpa, incentivando fontes renováveis, esse objetivo não deve ser realizado a qualquer custo. Por isso, para que a GDFV possa vir a ser parte relevante da matriz elétrica brasileira, uma avaliação econômica é primordial. 
Há diversos mecanismos de regulação utilizados para inserir e incentivar a energia fotovoltaica distribuída no mundo, como detalhado na seção 3.1. Porém, não basta inserir essas fontes na matriz energética por meio de subsídios, deve-se sim criar mecanismos para que elas se tornem competitivas a médio ou longo prazo.

O momento no qual os custos da energia gerada pela GDFV são iguais ao preço de venda de energia ao consumidor final é chamado de paridade tarifária. Esta configuração é considerada um ponto decisivo para inserção da energia fotovoltaica em determinado mercado, estabelecendo um cenário no qual a indústria fotovoltaica se torne independente de subsídios governamentais. O sistema de compensação de energia claramente só começa a ser vantajoso depois de atingir a paridade tarifária, já que a GDFV não venderá sua energia excedente, somente será compensado por seu consumo.

No caso do Brasil, dois fatores forçam a convergência entre as curvas de custo de produção e venda de energia elétrica: as altas tarifas residenciais e a radiação solar superior às médias mundiais. Ou seja, espera-se que a GDFV alcance paridade tarifária em um futuro próximo no País (RUTHER et. al., 2011).

Nas unidades federativas em que não haja a paridade tarifária faz-se necessária outra modalidade de incentivo à GDFV, pois somente a compensação da energia gerada pelo consumidor/gerador com a concessionária (net-metering) não é economicamente atraente, já que a geração GDFV é mais dispendiosa que a tarifa cobrada pela energia convencional. O problema se agrava quando se coloca ainda a questão dos tributos e impostos sendo cobrados em cima da energia total consumida e não apenas sobre o consumo líquido.

\subsection{Financiamento}

Qualquer tipo de empreendimento de geração de energia necessita de investimentos e, muitas vezes, estes são feitos por meio de financiamentos. Quando se fala de GD, esses financiamentos são ainda mais importantes, já que os custos de implantação da geração distribuída fotovoltaica tornam impeditivo o investimento para grande parte da população brasileira (AFONSO, 2012). 
A energia fotovoltaica é, por natureza, uma tecnologia com custos de manutenção baixos, sem custos de combustível, mas tem uma necessidade de investimento inicial elevado. Isto levou alguns países a pôr em prática políticas que reduzam o investimento inicial, a fim de incentivar a tecnologia (IEA-PVPS, 2014a). A abertura de uma linha de crédito especialmente direcionada ao financiamento desses empreendimentos é uma necessidade ainda a ser enfrentada pelo governo. Essas linhas de crédito devem ser específicas para a GDFV e o processo não pode ser burocrático a ponto de desmotivar o consumidor a instalar o sistema de geração.

\subsection{Impostos e tarifas}

A tarifa de energia elétrica que o consumidor cativo paga, aquele que só pode comprar energia elétrica de sua distribuidora local, é formada pelos custos incorridos desde a geração da energia até a sua disponibilização aos consumidores. $O$ consumidor paga uma parcela devida à compra na energia das geradoras, uma parcela de uso do sistema de transmissão e de distribuição e uma parcela referente aos encargos do sistema, impostos e tributos.

Os impostos e tributos são: Programas de Integração Social (PIS/PASEP), Contribuição para o Financiamento da Seguridade Social (COFINS), Imposto sobre a Circulação de Mercadorias e Serviços (ICMS) e Contribuição para Custeio do Serviço de Iluminação Pública (CIP); sendo PIS e COFINS a nível federal, ICMS a nível estadual e CIP a nível municipal. Somente o ICMS, que varia de estado para estado, pode responder, sozinho, por mais de $30 \%$ da conta de luz. A Figura 3.3 indica a composição tarifária média do Brasil (incluindo todos os consumidores brasileiros) em 2012. 


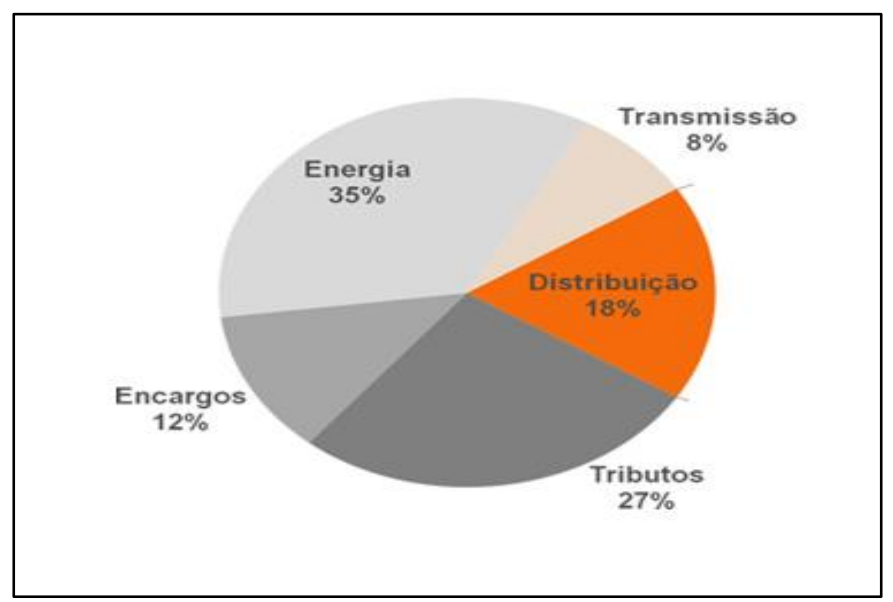

Fonte: ABRADEE - Associação Brasileira de Distribuidores de Energia Elétrica. Tarifas de energia. Disponível em: $\quad \underline{\text { http://www.abradee.com.br/setor-de-distribuicao/tarifas-de- }}$ energia/tarifas-de-energia $>$. Acesso em: dezembro de 2014.

Figura 3.3 Composição tarifária média do Brasil.

No sistema de compensação de energia, a incidência desses impostos deve ser cuidadosamente analisada. Se a incidência desses impostos for sobre o total de energia consumida, o excedente da geração própria não será levado em consideração para os cálculos dos impostos devidos, uma vez que a energia consumida será em algum momento compensada com energia gerada na unidade. No entanto, a legislação atual do país adota o consumo da unidade para realizar os cálculos dos impostos e tributos.

A definição sobre a cobrança de impostos e tributos federais e estaduais foge das competências da ANEEL ou distribuidoras de energia, cabendo à Receita Federal do Brasil e às Secretarias de Fazenda Estaduais tratar da questão.

\subsubsection{Sob a ótica da Sociedade}

\subsection{Fortalecimento da indústria nacional}

A geração solar fotovoltaica é uma fonte de energia relativamente nova e está ainda em período de constante evolução, tanto em avanços tecnológicos quanto em redução de custos, e isso deve ser incentivado para que essa fonte se torne cada vez mais competitiva. 
Por isso, diversos países que utilizam o mecanismo de tarifas prêmio, adotaram tarifas que variam com o tempo, mas sempre de forma programada, para que haja incentivo à eficiência e as tecnologias se tornem mais competitivas economicamente.

Quando se busca reduzir custos, o desenvolvimento de uma indústria nacional capaz de suprir a demanda interna é uma solução com diversos benefícios. Além da questão de redução de preços, uma indústria brasileira geraria empregos no país, desenvolvimento tecnológico e renda.

Esta industrialização, ainda que não incida sobre todos os equipamentos e componentes, é importante para assegurar a continuidade do programa, sob pena da GDFV nacional tornarse dependente da importação, o que contraria o interesse nacional de desenvolvimento (AFONSO, 2012).

\subsection{Interesse ambiental}

O aumento da participação das fontes renováveis de energia é resultado do anseio da sociedade em preservar o meio ambiente. É a consciência ambiental da população que motiva os governos e organizações a estabelecer metas e diretrizes no sentido da preservação. Os crescentes movimentos pela preservação ambiental representam a busca por um novo modelo de desenvolvimento, mais limpo e sustentável, para que as gerações futuras possam usufruir um planeta mais saudável.

É em nome dessa consciência ambiental que o consumidor optará por instalar sua GD, mesmo que o tempo de retorno do seu investimento seja maior do que em outras aplicações. A sociedade fará a escolha sabendo que essa energia limpa estará substituindo uma geração com maiores impactos ambientais e ainda estará promovendo eficiência energética, já que, com a geração próxima a carga, as perdas na transmissão serão reduzidas. 


\subsection{METODOLOGIA DE COMPARAÇÃO ENTRE OS INCENTIVOS ATUAIS NO BRASIL}

Qual a melhor maneira de incentivar o desenvolvimento da energia solar no Brasil? Essa questão se mostra de extrema importância no momento atual da tecnologia no país, já que duas configurações distintas de geração solar surgem como possibilidades viáveis.

No Brasil, duas formas diferentes de incentivo a energia solar vêm sendo conduzidas: a geração distribuída por meio da compensação financeira regulamentada pela RN ANEEL n482/2012 e a geração centralizada por meio de leilões específicos de energia.

A forma utilizada para comparar os dois modelos de incentivos existentes no país é calculando o custo dessas para a sociedade brasileira. Esse custo por ser arcado pelo consumidor de energia ou pelo contribuinte através dos impostos arrecadados pelo governo. Para esse cálculo é usado o Valor Presente Líquido (VPL) ${ }^{8}$ dos custos anuais. A planilha eletrônica Excel® possui essa fórmula inserida em seus modelos, facilitando os cálculos e, portanto, será utilizado neste trabalho.

No leilão de energia específico para a fonte solar, o valor do preço da energia vendida é superior aos praticados em leilões de livre competitividade e, portanto esse sobre preço é pago diretamente pelo consumidor de energia elétrica cativo das distribuidoras de energia. Há também um subsídio a esses investimentos quando o BNDES financia a taxas de juros menores que as habituais. Esses custos referentes ao subsídio do BNDES serão arcados pelo contribuinte.

No caso da geração solar distribuída, o grande entrave para a disseminação relevante dessa forma de geração é a dificuldade do consumidor em financiar a instalação, já que até o momento não há uma linha de crédito que se aplique a esse micro gerador. Portanto, foram criados cenários de incentivo, por meio de financiamento dos custos de instalação com juros subsidiados, que podem ser realizados por bancos públicos como o próprio BNDES.

\footnotetext{
${ }^{8}$ O VPL é a fórmula matemático-financeira capaz de determinar o valor presente de pagamentos futuros descontados a uma taxa de juros apropriada, menos o custo do investimento inicial..
} 
Para comparação desses dois modelos de geração, há que se considerar também o custo evitado da transmissão de energia, já que no caso da geração distribuída não há necessidade de investimento em transmissão, diferente do caso de grandes plantas de energia solar que usualmente se encontram longe dos centros de carga.

\subsubsection{Leilão específico para fonte solar}

O objetivo com esses leilões exclusivos é de criar uma demanda concreta para a energia solar no país e atrair as empresas do setor. Também são importantes para a criação de uma referência de preços e para preparar os empreendedores locais para futuros leilões.

Foram utilizados os dados do leilão de reserva de 2014, ocorrido em 31 de outubro de 2014, para estimar os custos para sociedade com esta modalidade de incentivo. Nesse leilão, os resultados obtidos estão descritos na Tabela 3.2.

Tabela 3.2 Dados do $6^{\circ}$ leilão de energia de reserva 2014 para fonte solar.

\begin{tabular}{|lr|}
\hline \multicolumn{2}{|c|}{ 6 $^{\circ}$ Leilão de Energia de Reserva - Fonte Solar } \\
\hline Montante a ser vendido - Fonte Solar [MW] & 889,70 \\
\hline Montante de energia a ser vendido por mês - Fonte Solar & $147.634,05$ \\
[MWh/mês] & $1.771 .608,60$ \\
\hline Energia vendida por ano - Fonte Solar [MWh/ano] & $35.432 .172,00$ \\
\hline Energia nos 20 anos de concessão - Fonte Solar [MWh] & 262,00 \\
\hline Preço teto do leilão - Fonte Solar [R\$/MWh] & 215,12 \\
\hline Preço médio do leilão - Fonte Solar [R\$/MWh] & 144,00 \\
\hline Preço teto do leilão - Fonte Eólica [R\$/MWh] & 142,34 \\
\hline Preço médio do leilão - Fonte Eólica [R\$/MWh] & 72,78 \\
\hline Diferença entre preço médio de Eólica e solar [R\$/MWh] & \\
\hline
\end{tabular}

Fonte: CCEE.

No leilão foram negociados $1.771 .608,60 \mathrm{MWh} / \mathrm{ano}$ a um preço médio de $\mathrm{R} \$$ 215,12/MWh. No mesmo leilão, a fonte eólica foi negociada a um preço médio de R\$ 142,34/MWh. Nota-se pelos valores diferentes nos preços da energia decorrente do leilão 
que o MWh gerado por fonte solar é mais caro que o gerado por fonte eólica, a diferença é de $\mathrm{R} \$ 72,78 / \mathrm{MWh}$. Essa diferença caracteriza o subsídio do leilão à fonte solar quando comparada a outras mais baratas.

No documento com o resultado do $6^{\circ}$ leilão de energia de reserva da CCEE (Anexo A), constam os dados de investimento em reais de cada um dos vencedores, assim como os preços e os montantes de geração. Portanto, o valor de investimento total dos empreendimentos vencedores somam $\mathrm{R} \$ 4.144 .227 .000$.

Assim, o objetivo é calcular o custo anual dessa diferença e o valor presente desse custo, descontando uma taxa de juros condizente com o custo de capital do Brasil. O custo médio da dívida pública brasileira em outubro de 2014 é de 11,63\% a.a., de acordo com Relatório Mensal da Dívida Pública Federal - Outubro/2014 realizado pela Secretaria de Tesouro Nacional do Ministério da Fazenda (STN/MF) e a inflação para o mesmo período é 5,5\%, sendo possível o cálculo dos juros reais, que corresponde à rentabilidade efetiva de um investimento financeiro.

Foi considerada a taxa de juros reais porque tanto a receita dos contratos de venda de energia no ambiente regulado (ACR) quanto os custos da energia sofrem correção pela inflação. Dessa forma, para construir o fluxo do sobre preço, que é a diferença de duas variáveis que crescem com a inflação, este também cresce com a inflação. Nesse trabalho, optou-se por considerar que esse sobre preço não crescerá pela inflação, sendo a conta realizada a preços correntes e uso da taxa de juros real.

Para determinar esse valor, utiliza-se a equação de Fisher (3.1):

$$
r=\frac{1+i}{1+\text { inflação }}-1
$$

Onde,

$\mathrm{i}=$ taxa de juros nominal; e

$r=$ taxa de juros real. 
Assim, no leilão específico para fonte solar, calcula-se o valor de taxa de juros real do governo brasileiro através da equação de Fisher.

$$
\text { Taxa de juros real } \text { Leilão }=5,81 \%
$$

Outra parcela do subsídio inerente a esse tipo de incentivo é o financiamento a juros baixos. A Tabela 3.1 contém os dados das linhas de créditos utilizadas pelo BNDES para os vencedores do leilão específico para fonte solar fotovoltaica do ano de 2014. Com esses dados, foram criados dois cenários de nacionalização dos empreendimentos, já que para cada "Fator N", a taxa de juros será diferente. A Tabela 3.3 apresenta esses valores. Para o Fundo Clima a taxa pode variar de $1,9 \%$ a 4,37\% a.a. a depender das garantias financeiras apresentadas e foi escolhido utilizar 1,9\% a.a. Para o FINEM, a variação é de 6,9\% a 9,37\% a.a., dado que TJLP é igual a 5\% e a remuneração da instituição de 0,5\% a.a.; e foi utilizada a menor taxa, de $6,9 \%$ a.a.

Assim, no cenário de nacionalização 100\%, o investidor tem acesso às melhores taxas de juros, pegando $15 \%$ do empréstimo pelo Fundo Clima e o restante, para inteirar os $70 \%$ possíveis, via FINAME. Essa suposição se deve, pois, geralmente, ao consumir o limite de crédito de uma linha, reduzem-se as demais. O prazo do financiamento é de 12 anos para o Fundo Clima e de 16 anos para o FINAME.

$$
\text { Taxa de Juros } \text { Cenário 100\% de Nacionalização }=\frac{(0,15 * 1,9 \%)+(0,55 * 5,7 \%)}{0,7}
$$

No cenário de mínima nacionalização, utiliza-se apenas o FINAME, com taxa de juros de $6,9 \%$ a.a. Em ambos os casos, foram utilizadas as menores taxas disponíveis pelo banco.

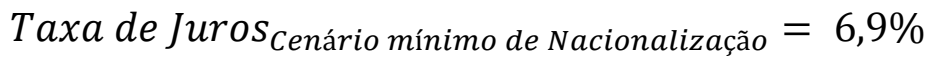


Tabela 3.3 Dados do Financiamento BNDES aos vencedores do Leilão Solar.

Financiamento dos empreendimentos vendidos no leilão

\begin{tabular}{|lrr|}
\hline \multicolumn{3}{|c|}{ Financiamento dos empreendimentos vendidos no leilão } \\
& $\begin{array}{c}\text { Cenário de } \\
\text { nacionalização }\end{array}$ & $\begin{array}{c}\text { Cenário de } \\
\text { mínima } \\
\text { nacionalização }\end{array}$ \\
\hline $\begin{array}{l}\text { Total dos investimentos a serem realizados pelos vencedores } \\
\text { do leilão [R\$] }\end{array}$ & 4.144 .227 .000 & 4.144 .227 .000 \\
\hline Proporção dos investimentos financiados pelo BNDES [\%] & 70 & 70 \\
\hline Prazo do financiamento [anos] & 16 & 16 \\
\hline Taxa de juros captação Tesouro [\% a.a.] & 11,63 & 11,63 \\
\hline Taxa de juros empréstimos BNDES [\% a.a.] & 5,7 & 6,9 \\
\hline
\end{tabular}

Cabe ressaltar que os custos com financiamento do BNDES não possuem contratualmente qualquer relação com a inflação e a premissa é que a inflação já esta embutida na taxa de juros, de forma que é possível calcular o valor exato da prestação sem depender da inflação.

Portanto, no caso do leilão, têm-se dois subsídios inseridos: o sobre preço da energia, com valor presente calculado utilizando-se a taxas de juros real da equação (3.2) e o subsídio concedido pelo BNDES pelo financiamento desses empreendimentos a taxa de juros reduzidas, que varia de acordo com o cenário de nacionalização escolhido: um de máxima nacionalização com taxa de juros final de 5,7\% a.a. e outro de mínima nacionalização, com taxa de juros final de 6,9\% a.a. Os cenários utilizados estão resumidos na Figura 3.4. 


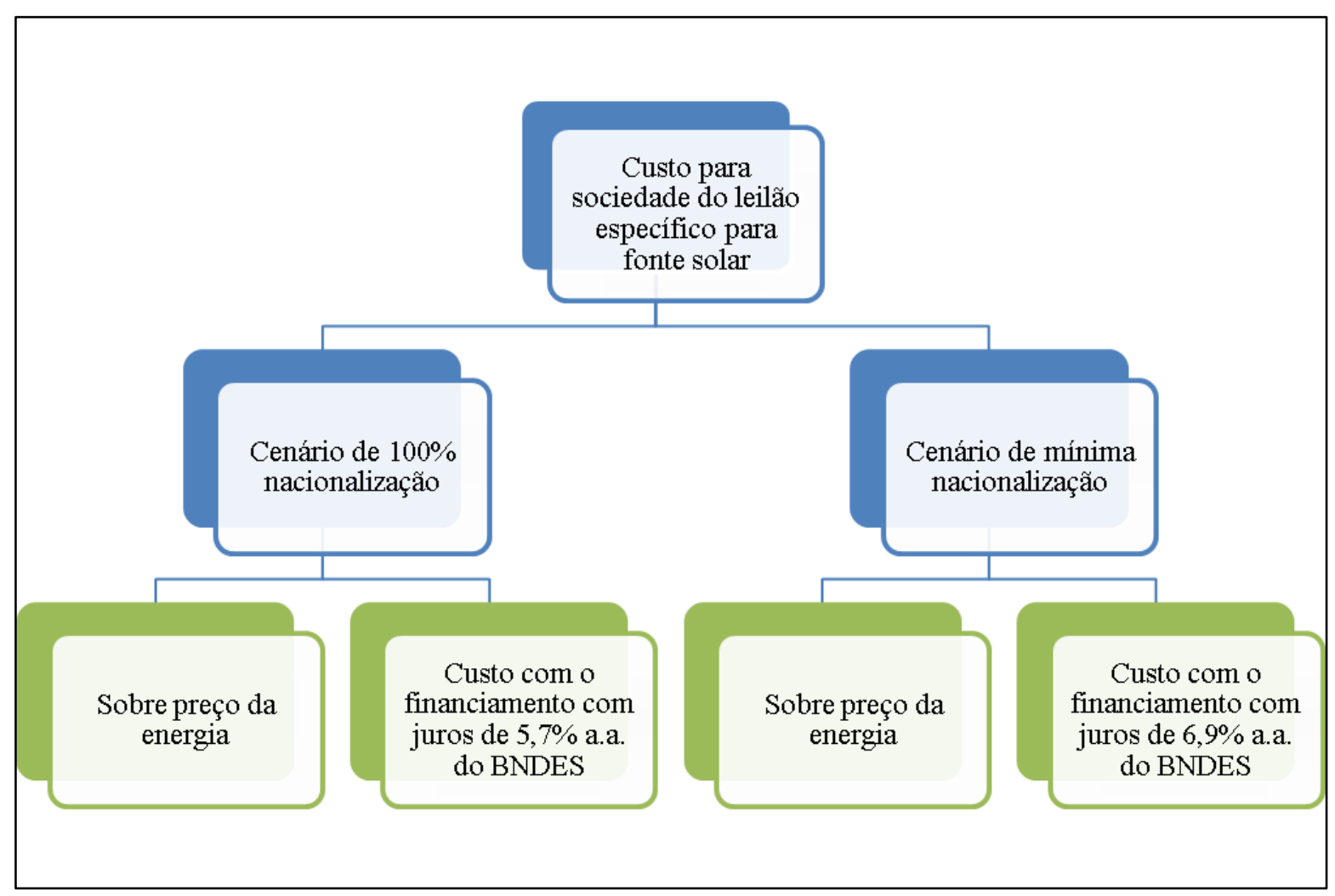

Figura 3.4 Custo para sociedade do leilão específico para a fonte solar.

\subsubsection{Geração distribuída}

A forma escolhida de simular o incentivo à geração distribuída foi a de viabilizar financiamentos subsidiados ao micro ou mini gerador que aderir o sistema de compensação financeira vigente desde a regulamentação ANEEL nº482/2012. Assim, algumas premissas foram generalizadas para simplificar o problema, elas estão na Tabela 3.4.

Tabela 3.4 Dados da simulação para GD.

\begin{tabular}{|lr|}
\hline \multicolumn{2}{|c|}{ Dados da Geração Distribuída } \\
\hline Hotência instalada média [kWp] & 3 \\
\hline Geração mensal por casa [kWh/mês] & 5 \\
\hline Geração anual por casa [kWh/ano] & 450 \\
\hline Custo de Instalação [R\$/kWp] & 5.475 \\
\hline Custo de geração [R\$/MWh] & 8.000 \\
\hline Custo da geração anual [R\$.ano/MWh] & 219,18 \\
\hline
\end{tabular}


Pelos valores médios das instalações utilizadas em residências no Brasil desde a entrada do sistema de compensação de energia, foi utilizado o valor de $3 \mathrm{kWp}$ como a média da potência instalada em um sistema, com custo médio de $\mathrm{R} \$ 8.000 / \mathrm{kWp}$ instalado. Foi estimado um valor médio de 5 horas de sol por dia, totalizando um total de geração de $5.475 \mathrm{kWh} /$ ano por sistema. Esses valores foram obtidos por uma pesquisa realizada pelo Portal Solar ${ }^{9}$ em janeiro de 2014 e estão de acordo com a média das potências instaladas até o momento, por meio da $\mathrm{RN}$ nº482/2012 (ANEEL, 2015).

Para se obter a mesma geração anual do leilão para fonte solar com geração distribuída, 1.771.608 MWh, e estimando o custo da GDFV em R \$ 8.000/ kWp instalado e a geração em $5.475 \mathrm{kWh} / \mathrm{ano}$, tem-se o custo da geração distribuída como:

$$
\text { Custo da instalação }=\frac{\text { Custo de Instalação total }}{\text { Geração em } 1 \text { ano }}=\frac{3 \times R \$ 8.000}{5,475 \frac{M W h}{a n o}}=4.383,56 \frac{R \$}{\frac{M W h}{a n o}}
$$

Para calcular o subsídio no financiamento da GD será fixado o montante de energia anual a ser gerado de forma a viabilizar o mesmo total vendido no leilão específico de 2014 , como parâmetro de comparação.

Assim, o total de recursos necessários para implementar o mesmo montante de energia pode ser calculado pela equação 3.6.

Total dos investimentos em GD = Energia gerada por ano x Custo anual da GD

$$
=1.771 .608,60 \frac{\mathrm{MWh}}{\mathrm{ano}} x 4.383,56 \frac{R \$}{\frac{M W h}{a n o}}=R \$ 7.765 .955 .507
$$

Os dados para simular os gastos com a GD estão resumidos na Tabela 3.5. Para esses financiamentos, os custos, da mesma forma que no financiamento do BNDES para os

\footnotetext{
${ }^{9}$ Disponível em: http://www.portalsolar.com.br/quanto_custa_a_energia_solar_fotovoltaica.html . Acesso em 09 de dezembro de 2014.
} 
leilões, não possuem relação com a inflação, ou seja, esta já esta embutida na taxa de juros de empréstimo.

Tabela 3.5 Dados da simulação para GD.

\begin{tabular}{|lr|}
\hline \multicolumn{2}{|c|}{ Dados dos cenários de financiamento } \\
\hline $\begin{array}{l}\mid \\
\text { Valor dos investimentos a serem financiados para o total de geração }\end{array}$ & 7.765 .955 .507 \\
\hline distribuída [R\$] & 100 \\
\hline Proporção dos investimentos financiados pelo BNDES [\%] & 20 \\
\hline Prazo do financiamento [anos] & 11,63 \\
\hline Taxa de juros captação Tesouro [\%] & 1 \\
\hline Taxa de juros a.a. empréstimos BNDES - Cenário 1 [\%] & 3,5 \\
\hline Taxa de juros a.a. empréstimos BNDES - Cenário 2 [\%] & 5 \\
\hline Taxa de juros a.a. empréstimos BNDES - Cenário 3 [\%] & 10 \\
\hline Taxa de juros a.a. empréstimos BNDES - Cenário 4 [\%] & \\
\hline
\end{tabular}

Foram propostos quatro cenários de financiamento com taxas de juros diferentes: de $1 \%$, de $3,5 \%$, de $5 \%$ e de $10 \%$, se aproximando às altas taxas de juros do Brasil. Em cada cenário, foi calculado o VPL dos investimentos utilizando a taxa de juros real, que variará para cada cenário.

Para a energia distribuída, foi levado em consideração o custo evitado com investimentos em transmissão de energia elétrica, já que, nesse modelo, carga e geração estão no mesmo ponto da rede e o excedente será consumido nas proximidades do micro gerador. O sistema de transmissão é planejado para atender a ponta do sistema, ou seja, o momento de maior consumo. Em várias áreas de concessão o horário de ponta se modificou, devido às altas temperaturas e ao grande crescimento da utilização de aparelhos de ar condicionado. A geração solar fotovoltaica tem sua maior geração nas horas do dia em que há maior incidência de energia solar, ou seja, a utilização dessa fonte contribui diretamente na diminuição da ponta da demanda.

Assim, considera-se o custo médio da tarifa de energia para o consumidor residencial em baixa tensão como R\$ 392/MWh, valor no ano de 2013, disponível no "Relatório do Sistema de Apoio a Decisão: Consumidores, Consumo, Receita e Tarifa Média - Classe de 
Consumo" da ANEEL. De acordo com a ABRADEE, o percentual médio do custo de transmissão na conta do consumidor de baixa tensão é de 8\% (Figura 3.3). Assim, é calculado o VPL desse investimento evitado, que será subtraído do total do VPL do subsídio da geração distribuída (Tabela 3.5).

Tabela 3.6 Dados do custo evitado em transmissão.

\section{Dados do custo evitado em transmissão}

Energia vendida por ano [MWh]

$1.771 .608,60$

Preço médio da tarifa de energia pro consumidor BT [R\$/MWh] 392

Percentual médio referente ao custo de transmissão [\%] 8

$\begin{array}{ll}\text { Taxa de juros captação Tesouro [\%] 11,63 } & \text { 1\% }\end{array}$

Parte da tarifa para o custo de transmissão [R\$/MWh] $\quad 31,4$

Redução do custo de transmissão com geração distribuída [R [ ] 55.557 .646

É possível calcular a redução dos custos de transmissão pela equação:

Redução do custo de transmissão com geração distribuída

$=$ Energia anual $x$ Parte da tarifa para custo de transmissão

$=1.771 .608,60 \times 31,4=R \$ 55.557 .646$

Assim, no caso da geração distribuída, duas parcelas devem ser consideradas em cada cenário para simular o custo para a sociedade nesse caso de incentivo, como pode ser observado na Figura 3.5. 


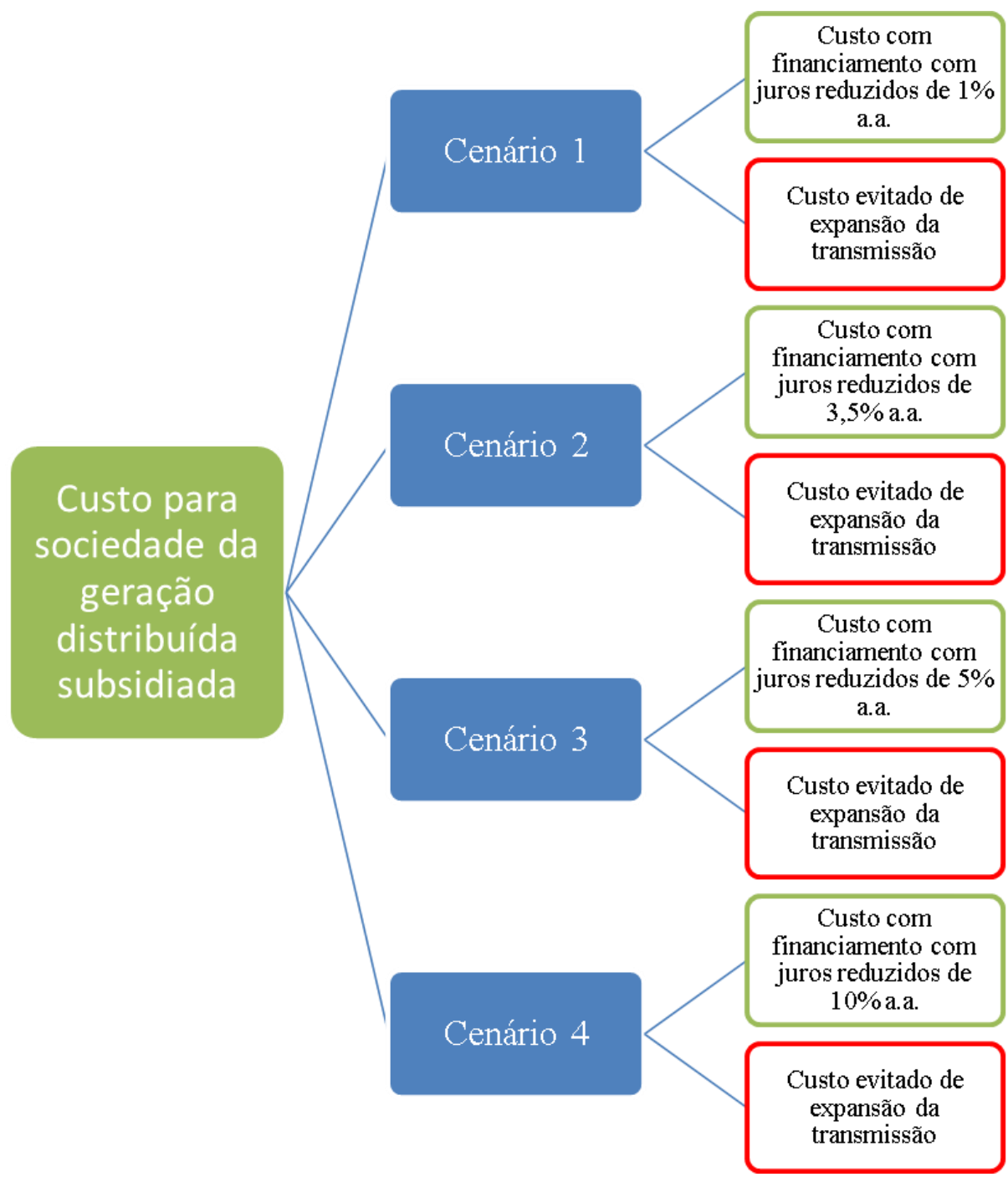

Figura 3.5 Custo para sociedade da GD subsidiada.

\subsubsection{Cálculo do Valor Presente}

Para Cálculo do valor presente, são necessários os seguintes argumentos: taxa de juros; período de Pagamento e valor a ser financiado. Assim, para que o processo realizado possa ser reproduzível, os argumentos utilizados em cada etapa da simulação são: 


\subsubsection{Leilão Específico}

\begin{tabular}{|l|c|c|c|}
\multicolumn{2}{|c}{ Dados } & \multicolumn{4}{c|}{ Subsídio Leilão } \\
\cline { 2 - 4 } & $5,81 \%$ & $\begin{array}{c}\text { Cenário de } 100 \% \text { de } \\
\text { nacionalização }\end{array}$ & $\begin{array}{c}\text { Cenário de mínima } \\
\text { nacionalização }\end{array}$ \\
\hline Taxa de juros final & 20 anos & $5,92 \%$. & $4,73 \%$. \\
\hline Período & $\mathrm{R} \$ 128.937 .674$ & $\mathrm{R} \$ 2.900 .958 .900$ & $\mathrm{R} \$ 2.900 .958 .900$ \\
\hline $\begin{array}{l}\text { Valor a ser } \\
\text { financiado }\end{array}$ & & & 16 anos \\
\hline
\end{tabular}

\subsubsection{GD}

\begin{tabular}{|l|c|c|c|c|}
\hline \multicolumn{1}{|c|}{ Dados } & Cenário 1 & Cenário 2 & Cenário 3 & Cenário 4 \\
\hline Taxa de juros final & $10,63 \%$ & $8,13 \%$ & $6,63 \%$ & $1,63 \%$ \\
\hline Período & 20 anos & 20 anos & 20 anos & 20 anos \\
\hline $\begin{array}{l}\text { Valor a ser } \\
\text { financiado }\end{array}$ & $\mathrm{R} \$ 7.765 .955 .507$ & $\mathrm{R} \$ 7.765 .955 .507$ & $\mathrm{R} \$ 7.765 .955 .507$ & $\mathrm{R} \$ 7.765 .955 .507$ \\
\hline
\end{tabular}

\subsubsection{Custo evitado de Transmissão}

\section{Dados}

\section{Custo evitado de transmissão}

\section{Taxa de juros final}

Período

Valor a ser financiado

$11,63 \%$

20 anos

$\mathrm{R} \$ 55.557 .646$ 


\subsection{CONSIDERAÇÕES FINAIS}

Os diversos mecanismos de suporte ao desenvolvimento da energia solar fotovoltaica apresentados são medidas que podem ser viáveis no Brasil, a depender do interesse governamental em promover uma política com essa finalidade. Como já foi relatado, o governo brasileiro já iniciou a regulamentação dos incentivos, optando inicialmente pelo leilão específico e o sistema de compensação de energia. Porém há a necessidade de melhora da regulamentação nacional em alguns pontos, destacando-se a necessidade de financiamentos a juros baixos para a GDFV. O capítulo seguinte traz o resultado da metodologia de comparação entre os incentivos propostos, bem como sugestões de mudanças no cenário regulatório para desenvolvimento da geração distribuída. 


\section{RESULTADOS E ANÁLISES}

Nesse capítulo são apresentados os resultados obtidos e são feitas as análises. Primeiramente, estão os resultados das simulações e cenários quanto à forma de incentivo mais apropriada ao País, ou seja, o mecanismo que deve ser fortalecido para que o crescimento da geração solar fotovoltaica ocorra de forma mais acelerada e segura. Em seguida, serão apresentadas as mudanças sugeridas na regulamentação atual da geração distribuída no Brasil para um desenvolvimento mais rápido e robusto da capacidade instalada de geração solar fotovoltaica. Essas mudanças são aplicadas principalmente à RN n 482/2012 e ao PRODIST, mas também a questões estruturais como a tributária e a de financiamento estatal.

\subsection{INCENTIVO MAIS APROPRIADO PARA O BRASIL}

A simulação dos dois mecanismos vigentes no Brasil apresentou os resultados relatados nas Tabela 4.1e Tabela 4.2, referentes a cada um dos cenários.

Tabela 4.1 Custos para sociedade com o leilão específico para fonte solar.

\begin{tabular}{|c|c|c|c|c|}
\hline \multicolumn{5}{|c|}{ Custos pra sociedade } \\
\hline \multicolumn{2}{|c|}{ Leilão de geração solar } & $\begin{array}{l}\text { Sobre preço em } \\
\text { relação a outras } \\
\text { fontes renováveis }\end{array}$ & $\begin{array}{c}\text { Subsidio BNDES } \\
\text { financiamento }\end{array}$ & Total \\
\hline \multirow{2}{*}{ 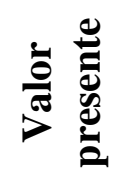 } & $\begin{array}{l}\text { Cenário de } 100 \% \text { de } \\
\text { nacionalização }\end{array}$ & \multirow{2}{*}{$\mathrm{R} \$ 1.501 .988 .965$} & $\mathrm{R} \$ 915.459 .375$ & R\$ 2.417.448.340 \\
\hline & $\begin{array}{l}\text { Cenário de mínima } \\
\text { nacionalização }\end{array}$ & & $\mathrm{R} \$ 730.998 .672$ & $\mathrm{R} \$ \mathbf{2 . 2 3 2 . 9 8 7 . 6 3 7}$ \\
\hline
\end{tabular}


Tabela 4.2 Custos para sociedade com a geração distribuída subsidiada.

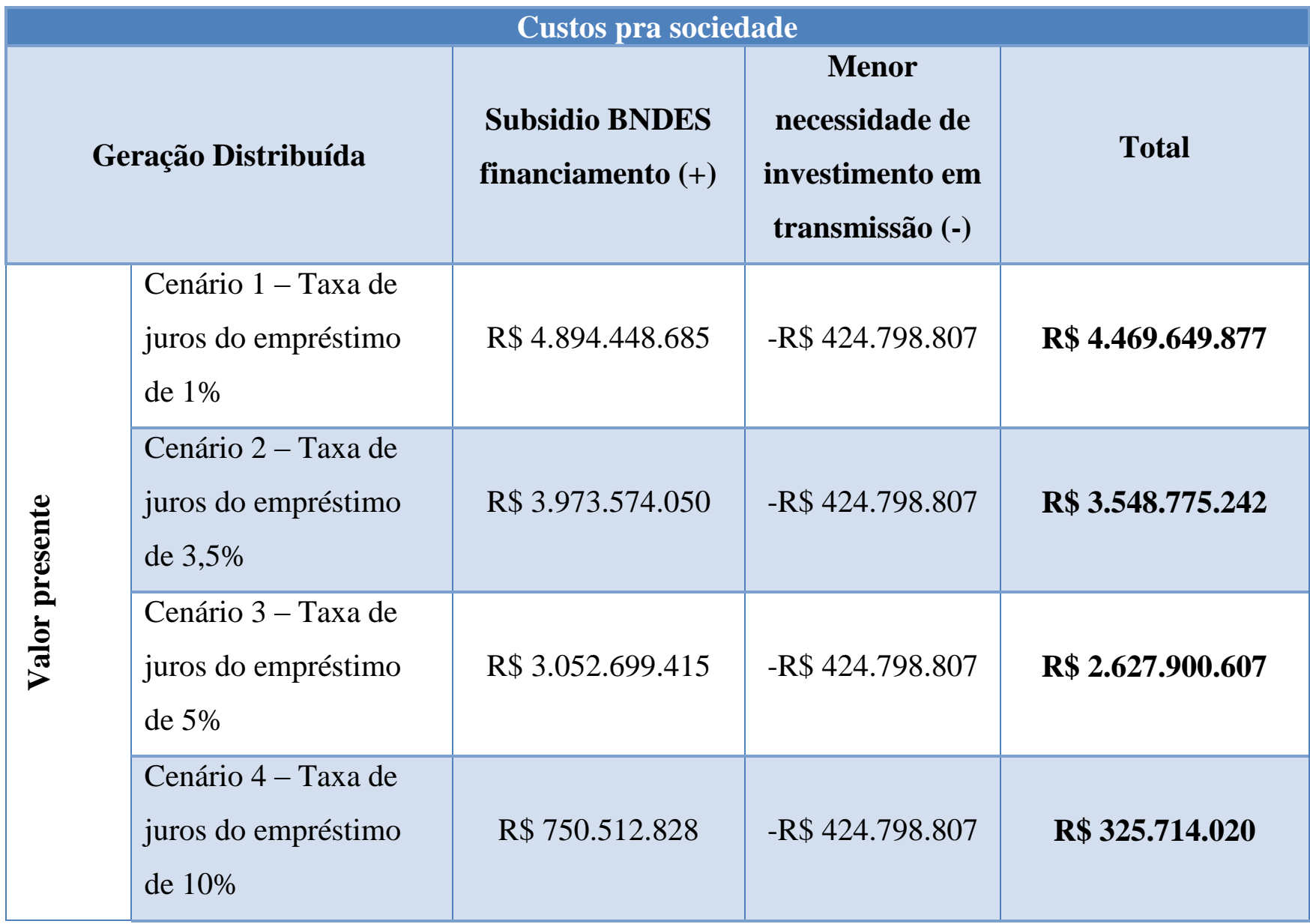

Das tabelas, chega-se ao resultado que os custos para sociedade dos $1.771 .608 \mathrm{MWh} / \mathrm{ano}$ vendidos no leilão somam 2,4 bilhões de reais no cenário de $100 \%$ de nacionalização e 2,2 bilhões de reais, no cenário de mínima nacionalização, devido ao sobre preço da energia e do subsídio no financiamento com banco público.

Para geração distribuída, o custo de se financiar os empreendimentos a taxas de juros mais atrativas varia de acordo com a taxa escolhida. No cenário de menor taxa, ou seja, mais atrativo ao investidor, os custos foram muito superiores ao custo do leilão: 4,4 bilhões de reais. No cenário intermediário de taxa de juros de 5\% a.a., os custos já se tornam competitivos, 2,6 bilhões de reais. No último caso, com as taxas de juros altas, o custo seria mínimo para sociedade, devido à postergação de investimentos em transmissão. No entanto, taxas de juros elevadas podem não ser atrativas para o investidor.

Por sim, foi realizada uma análise de sensibilidade do custo do financiamento de GDFV, alterando a taxa de juros disponibilizada pelo BNDES de $0,1 \%$ a $10 \%$ a.a., com intervalos 
de $0,1 \%$. Essa curva foi comparada aos custos do leilão específico para energia solar, na Figura 4.1.

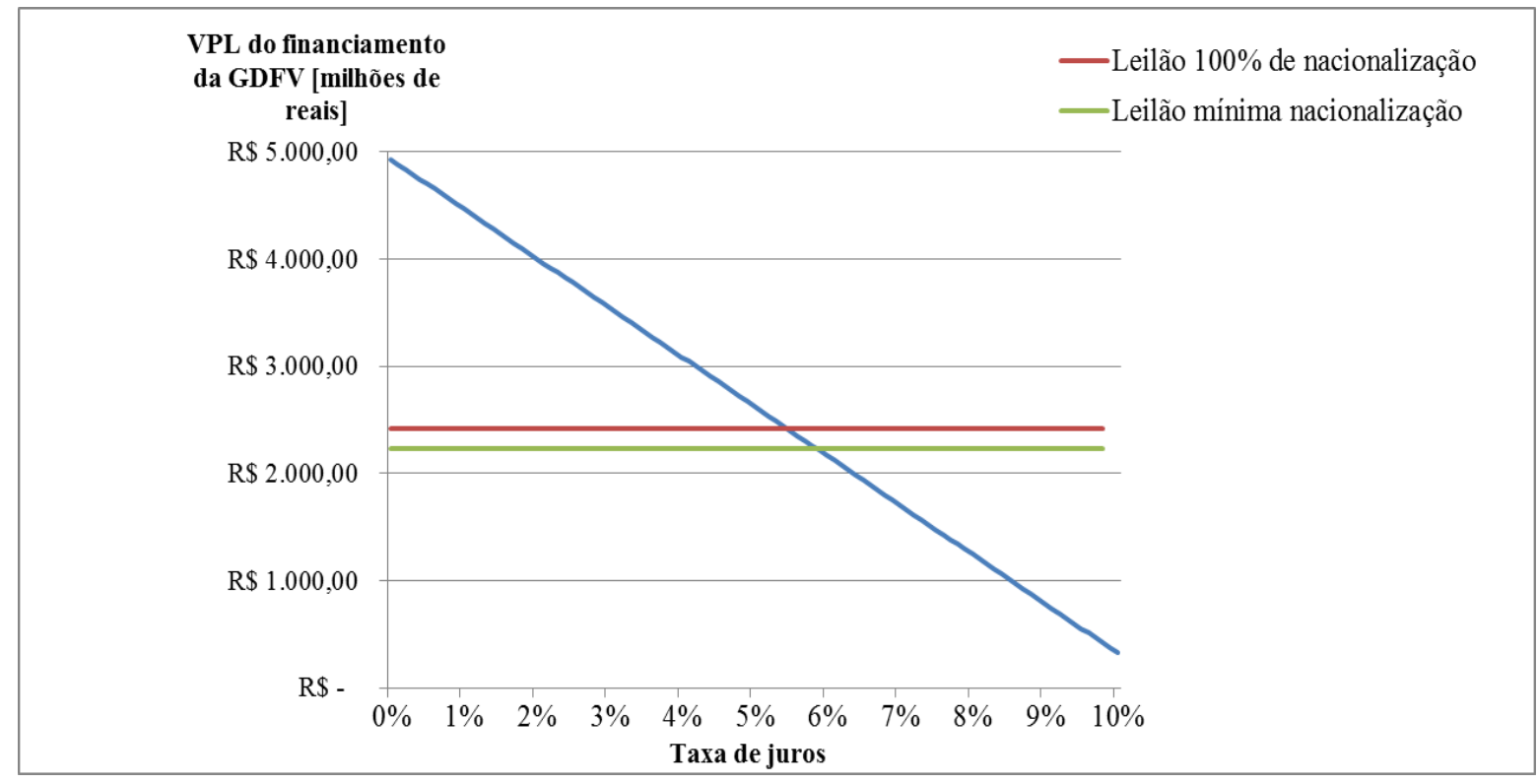

Figura 4.1 Análise de sensibilidade do custo para a sociedade do financiamento da GDFV

Nota-se pela figura que o custo da GDFV é igual ao custo do leilão no cenário de $100 \%$ de nacionalização com taxa de juros 5,7\% a.a., e é igual ao custo do leilão no cenário de mínima nacionalização com taxas de juros de 5,3\% a.a.

Portanto, se taxas de juros subsidiadas fossem disponibilizadas ao micro gerador, valores próximos a 6\%, a GD seria uma opção atrativa e economicamente mais favorável à sociedade brasileira, quando comparada aos leilões específicos de energia solar. Vários países praticaram empréstimos com taxas de juros dessa mesma ordem, como, por exemplo, a Alemanha.

Os resultados mostram que leilões de energia específicos para a fonte solar, embora tenham um impacto significativo para os consumidores e contribuintes, se mostram uma opção econômica mais atrativa que o subsídio à geração distribuída, sem um financiamento com condições favoráveis ao investidor, quando observada a ótica dos custos dessa geração para a sociedade como um todo. A geração solar centralizada é considerada complementar à geração hidrelétrica e deve ser avaliada junto com a operação dos 
reservatórios, no processo de variações do armazenamento de energia na forma de estoque de água.

No entanto, tanto a geração centralizada quanto a GD tendem a ganhar maior atratividade econômica com a instalação de novos empreendimentos no país, trazendo não só investidores, como também a cadeia produtiva a se instalar no Brasil. As Regras de nacionalização progressiva existentes para o financiamento pelo BNDES desses empreendimentos estimulam a criação de uma cadeia produtiva de equipamentos fotovoltaicos no Brasil, desenvolvendo a indústria. O governo pretende sinalizar que leilões de energia solar devem ocorrer anualmente. A meta oficial do governo é alcançar 3.500 MW de capacidade instalada até 2023, no entanto, essa meta já foi considerada conservadora pelo próprio governo (MME/EPE, 2014).

A crise que reduziu investimentos nesse tipo de tecnologia na Europa e nos EUA nos últimos anos, aliado aos preços recordes da energia no Brasil, fizeram com que grandes empresas, nacionais e internacionais, começassem a se interessar por esse mercado e a tendência é esse interesse aumentar nos próximos anos.

O modelo de compensação financeira vigente em conjunto com os leilões de energia propicia um mercado promissor e atrativo para novos investimentos. $\mathrm{O}$ cenário tende a mudar com a sinalização dada pelo governo federal de que essa fonte será objeto de novos leilões, anuais. Com a expansão do uso da GD, o mercado passará a investir mais e isso estimulará a produção nacional em equipamentos, produção vital para viabilizar as metas de nacionalização, exigidas pelo Banco Nacional de Desenvolvimento Econômico e Social (BNDES) para os financiamentos dos empreendimentos ligados à geração de energia. No cenário atual, com problemas de estiagem e abastecimento de água, outras fontes energéticas podem ajudar a diminuir o risco de racionamento de energia no futuro.

\subsection{MUDANÇAS NO CENÁRIO REGULATÓRIO BRASILEIRO PARA DESENVOLVIMENTO DA GD}

A publicação da RN ANEEL nº 482 em 2012 permitiu um novo paradigma na expansão das redes de distribuição. Isso porque, no novo cenário, não é mais somente a concessionária que, após estudo adequado, decide o local, o momento e a quantidade de 
energia que será injetada na rede. Agora há a figura do consumidor/gerador. Com a implantação da GD, o consumidor, que tem garantido o direito de se conectar à rede de distribuição, irá definir a quantidade de energia que injetará na rede da distribuidora no ponto em que está conectado.

Um mudança interessante seria a possibilidade do micro e mini gerador de energia receber pela energia gerada em excesso, o que poderia diminuir o tempo de retorno do seu investimento e incentivar a instalação de maiores capacidades.

\subsubsection{PRODIST e normas das distribuidoras}

Buscando avaliar a forma como as distribuidoras farão a gestão da GD, foram analisadas algumas das normas para o tema após a RN ANEEL 482/2012. Após um estudo amplo da normatização criada pelas concessionárias, a ANEEL publicou revisão do módulo 3 do PRODIST, que traz os aspectos gerais do acesso ao sistema dessas distribuidoras.

As normas em questão são, sem dúvida alguma, um passo importante para a inserção da GD no Brasil. No entanto, embora elas tenham sido feitas buscando tornar o processo transparente e desburocratizado, alguns pontos devem ser mais bem avaliados e, eventualmente, aprimorados.

\subsubsection{Prazo}

O PRODIST definiu os prazos e etapas para cada uma das atividades envolvidas no processo de instalação da GD, desde a solicitação do acesso à distribuidora até a efetiva conexão do acessante. De forma esquemática o processo foi estabelecido conforme a Figura 4.2. 


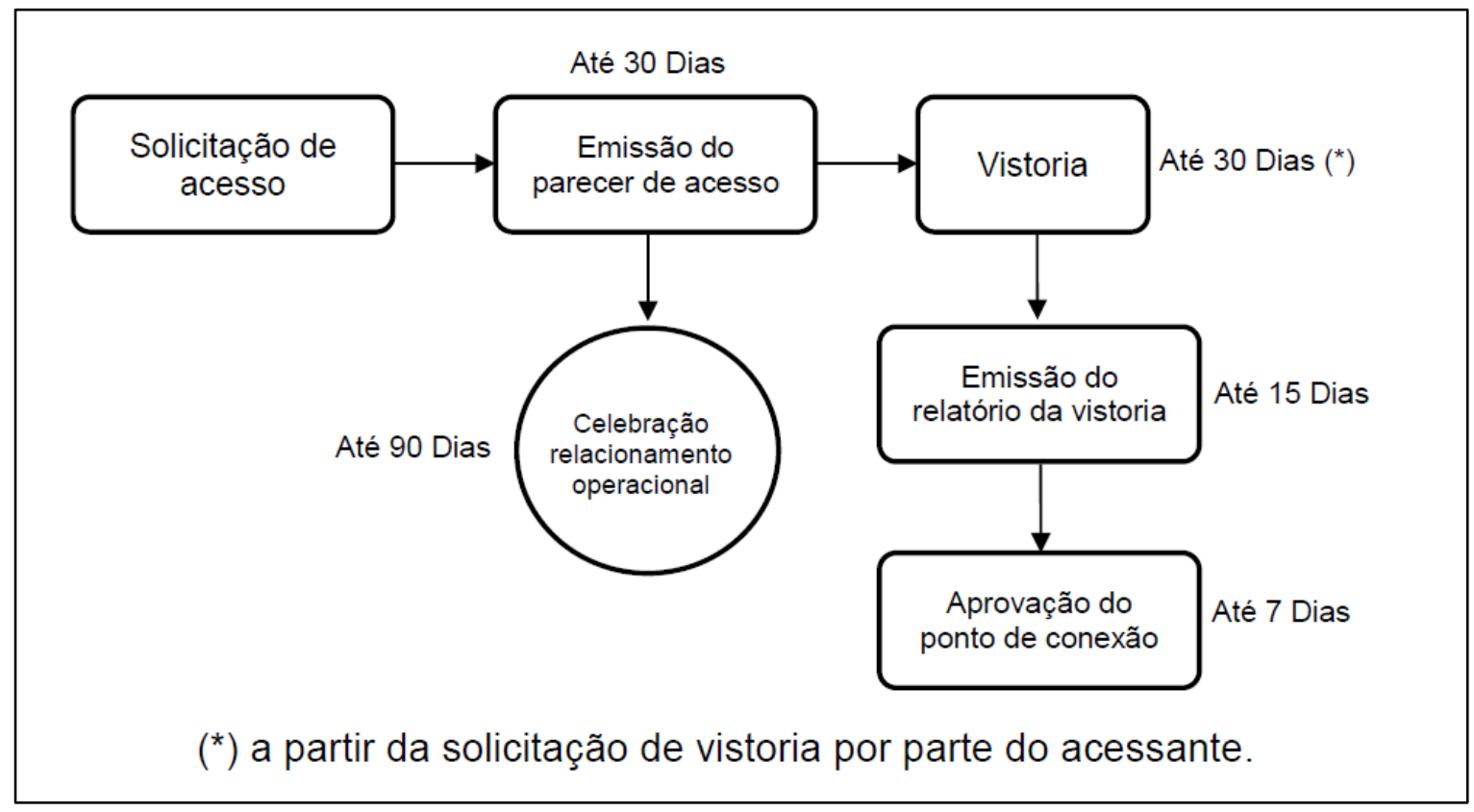

Fonte: CEB. NT 6.09.

Figura 4.2 Prazos das Distribuidoras nas etapas de acesso de Microgeradores ao Sistema de Distribuição.

Pelo processo estabelecido, a distribuidora tem 30 dias para emitir o seu parecer de acesso. No entanto, o impacto que a GD causa na rede de distribuição é um tema novo, com pesquisas em andamento (JUNQUEIRA, 2013; CAMARGO 2013; FERREIRA, 2013, SHAYANI, 2011), e ainda não existe um método normatizado que permita à distribuidora fazer o estudo dentro desse prazo (SHAYANI, 2010). Certamente, o processo de avaliação será bastante simplificado em um momento inicial, em que se espera um número modesto de pedidos de ligações. Entretanto, com o avanço da tecnologia de fabricação das placas fotovoltaicas e diminuição dos preços, poderá haver um grande aumento no número de solicitações de acesso.

Dada a grande diversidade existente entre as áreas de concessão para o serviço de distribuição no Brasil, bem como a diferença técnica existente entre as concessionárias e permissionárias do setor, espera-se que alguns agentes não tenham meios para atender todos os pedidos de conexão para GD em tempo razoável. $\mathrm{O}$ atraso na ligação de um consumidor pode implicar em prejuízo significativo, podendo inclusive frustrar o retorno do investimento feito, já que, ao solicitar o acesso, o consumidor tem um cronograma de implantação, e, possivelmente, tenha investido recursos tanto nos estudos quanto na compra de equipamentos. Ademais, o consumidor pode exigir na justiça o ressarcimento 
relativo ao que deixou de gerar, causando um pagamento de uma energia que não foi gerada. Os prazos estabelecidos nas normas das distribuidoras e no PRODIST devem ser objeto de análise mais aprofundada após a adoção de uma metodologia clara e uniforme de inserção da GD.

\subsubsection{Responsabilidades do acessante e da distribuidora}

Merece destaque a prerrogativa dada à Concessionária para desconectar uma determinada unidade consumidora, cuja geração esteja prejudicando a operação da rede, de acordo com o trecho que segue, retirado da norma da distribuidora CEB:

\section{Norma Técnica CEB $n^{\circ} 6.09$}

A CEB-D poderá interromper o acesso ao seu sistema quando constatar a ocorrência de qualquer procedimento irregular ou deficiência técnica elou de segurança das instalações de conexão que ofereçam risco iminente de danos a pessoas ou bens, ou quando se constatar interferências, provocadas por equipamentos do acessante, prejudiciais ao funcionamento do sistema elétrico da acessada ou de equipamentos de outros consumidores.

A prática descrita aliada a um consumidor/gerador conectado em um trecho precário da rede da Distribuidora pode levar à interrupção sistemática da geração na UC em questão, mesmo que a GD tenha sido construída dentro de todos os critérios técnicos e aprovada pela distribuidora, levando a um retardo significativo no prazo de retorno do investimento aportado no sistema de geração.

As normas separam como obras de responsabilidade do acessante aquelas de conexão de uso restrito e aquelas para instalações do ponto de conexão. A cargo da Distribuidora ficam as obras de reforma ou reforço em seu próprio sistema de distribuição para viabilização da conexão da microgeração, "respeitando os prazos habitualmente utilizados para tal". Existe ainda a possibilidade do acessante assumir a execução das obras de reforço ou reforma da rede acessada seguindo os procedimentos da distribuidora. Posteriormente, a concessionária ficará responsável pelo ressarcimento dos custos referentes a essas obras conforme Resolução Normativa ANEEL nº 482 de 2012. 
O próximo passo regulatório deverá definir como as distribuidoras devem considerar a GD na expansão e nos reforços de suas redes. Para isso, é necessário que haja um levantamento estatístico de quais consumidores podem se conectar, bem como o momento em que isso deve ocorrer. Como a conexão de um novo consumidor/gerador não deve ter impactos negativos para a qualidade do serviço, a distribuidora deve possuir regras claras de prioridade para o atendimento de novos pedidos. Preventivamente, as redes devem ser reforçadas de forma a possibilitar a geração do máximo de GD a partir de fontes renováveis, respeitando os limites impostos pela modicidade tarifaria.

As redes de distribuição devem estar preparadas para abrigar esse tipo de geração, pois o caráter de radialidade, tradicionalmente presente nesses sistemas, dá lugar a redes que operam com multigeradores. Esse fato requer atenção na gestão dos níveis de tensão, no controle dos reativos e na forma de operação e de conexão dessas centrais. O caráter intermitente, sujeitos a incerteza climática do sombreamento resultante das nuvens traz peculiaridades operativas a um sistema de distribuição que abriga grande capacidade de oferta fotovoltaica.

\subsubsection{C Critérios para seleção de projetos de GD}

Não constam nas normas um critério para seleção de projetos, o que pode representar uma dificuldade para a implementação dos sistemas. Essa seleção poderia ser feita de diversas maneiras, por exemplo, por ordem de data da solicitação, sendo o primeiro a solicitar a conexão, o primeiro a ser analisado; ou pelo custo da preparação da rede, já que dependendo do local da rede onde o consumidor se encontre, os custos e obras necessárias para adequação do sistema de distribuição pode variar consideravelmente. A falta de definição é uma deficiência, já que os custos envolvidos com a adequação da rede para ingresso dos novos acessantes são pagos por todos os consumidores da área de concessão da distribuidora acessada.

Nesse sentido, para que haja generalidade no serviço, a distribuidora deve estar com sua rede apta a receber essa geração, onde quer que o acessante pretenda instalá-la. Uma proposta seria a divulgação de metas por região e planos periódicos de expansão da GD, realizando consultas periódicas a possíveis interessados em aderir ao sistema em um médio prazo. 


\subsubsection{Metodologia para inserção da GD}

Já existem trabalhos acadêmicos que buscam delimitar o limite de penetração fotovoltaico (SHAYANI, 2010; GUEDES, 2013.) bem como avaliar os impactos do incremento de GD em determinados alimentadores (JUNQUEIRA, 2013). Porém, ainda não há uma metodologia normatizada e amplamente utilizada que permita identificar os reforços de rede prudentes a serem efetuados, sem afetar a modicidade tarifária e sem prejudicar a qualidade da energia.

A falta de uma metodologia que leve em consideração a GD na expansão e modernização da rede é um ponto essencial e que deve ser abordado pela regulação com brevidade. Isso evitará que novas conexões de GD sejam inviabilizadas, além de evitar que novas expansões fiquem obsoletas, do ponto de vista da ligação da GD, ou que a distribuidora faça reforços desnecessários, o que geraria retrabalho e custo adicional, prejudicando a modicidade tarifária. Assim, um criterioso planejamento prévio é exigido. O planejamento das redes de distribuição passa a exigir profundas mudanças, tanto no projeto, quanto no dimensionamento dos sistemas de operação e controle. Há a necessidade de se rever, alterar e adaptar as redes de distribuição existentes hoje em dia. Estas intervenções na rede são necessárias para que não ocorram violações nos parâmetros nominais dos equipamentos (JUNQUEIRA, 2013).

\subsubsection{Financiamento}

O Governo Federal, no âmbito do Plano Brasil Maior (MDIC, 2011) colocou como um dos objetivos a criação de linhas de crédito no Banco do Brasil e Caixa Econômica Federal para o financiamento de equipamentos e serviços de GD. As linhas comerciais disponíveis são menos atrativas e, portanto, poderiam não viabilizar a geração distribuída. Portanto, o financiamento a esses novos geradores é um problema que o Governo ainda não conseguiu solucionar e deve ser discutido nas esferas federal e estadual. Percebe-se claramente a existência de financiamentos em condições mais atrativas para pessoas jurídicas do que para os cidadãos que aderirem ao sistema de compensação financeira vigente. Estudos da EPE indicam que juros reais de $4 \%$ ao ano já dariam estímulo ao investimento na GDFV (EPE, 2012). 


\subsubsection{Questões tributárias}

Recentemente com o inicio do sistema de Compensação Financeira para a micro e mini geração distribuída, ficou evidente a incidência inadequada dos impostos sobre toda a energia consumida, independente do quanto foi injetado de volta na rede.

O Conselho Nacional de Política Fazendária - CONFAZ aprovou o Convênio ICMS 6, de 5 de abril de 2013, estabelecendo que o ICMS apurado tem como base de cálculo toda energia que chega à unidade consumidora proveniente da distribuidora, sem considerar qualquer compensação de energia produzida pelo micro gerador. Com isso, a alíquota aplicável do ICMS incide sobre toda a energia consumida no mês. Deve-se ressaltar que a ANEEL possui entendimento diverso em relação à cobrança do ICMS no âmbito do sistema de compensação, pois a energia elétrica injetada é cedida, por meio de empréstimo gratuito, à distribuidora e posteriormente compensada com o consumo dessa mesma unidade consumidora ou de outra unidade consumidora de mesma titularidade da unidade consumidora onde os créditos foram gerados.

A lei 20.824, 31 de julho de 2013, promove alteração na legislação tributária de Minas Gerais e insere a seguinte novidade:

"Pelo prazo de cinco anos, contado da data de início da geração de energia, a base de cálculo do imposto, relativamente às operações do micro gerador e do mini gerador de energia elétrica participantes do sistema de compensação de energia elétrica, de que trata a Resolução Normativa n 482/2012 da Agência Nacional de Energia Elétrica - Aneel -, será reduzida, de forma que corresponda à diferença positiva entre a entrada de energia elétrica fornecida pela empresa distribuidora e a saída de energia elétrica com destino à empresa distribuidora." Essa alteração se restringe ainda a apenas alguns estados da Federação, como Minas Gerais, São Paulo, Goiás e Pernambuco, pois o Governo Federal não adotou a medida nacionalmente.

O Programa de Integração Social (PIS) e a Contribuição para o Financiamento da Seguridade Social (COFINS) obedecem ao regime de tributação não cumulativo, isto é, cada etapa da cadeia produtiva se apropria dos créditos decorrentes das etapas anteriores. As alíquotas estabelecidas são: PIS, 1,65\%; COFINS, 7,60\% ; e PIS + COFINS , 9,25\%. A 
ANEEL determinou às concessionárias de distribuição de energia uma nova fórmula de cálculo para estas contribuições, tendo em vista que as alíquotas efetivas passaram a variar mensalmente em função dos créditos adquiridos nas etapas anteriores da cadeia. $\mathrm{O}$ custo do PIS e da COFINS passou, então, a ser calculado mensalmente. Atualmente, para o cálculo do montante de impostos a pagar, algumas distribuidoras aplicam a tarifa final com impostos (PIS/COFINS e ICMS) para todo o consumo, deduzindo-se o montante equivalente ao valor do consumo total com a tarifa sem impostos.

Os consumidores que decidirem aderir ao sistema de compensação de energia precisam considerar em seus cálculos de retorno financeiro diversos fatores ainda não estabelecidos ou não homogêneos no país como um todo. São eles: a concessionária de distribuição a que são conectados (diferentes tarifas de energia elétrica, em $\mathrm{R} \$ / \mathrm{kWh}$ ), o estado da federação (diferentes alíquotas de ICMS) e ainda o município (diferentes metodologias e /ou tarifas de iluminação pública). Em 2015, as dificuldades se tornarão maiores pela implementação das bandeiras tarifárias, que irão variar para diferentes regiões do país.

A visão da ANEEL é que a tributação deveria incidir apenas na diferença, se positiva, entre os valores finais de consumo e energia excedente injetada (geração). Caso a diferença entre a energia consumida e gerada seja inferior ao consumo mínimo, a base de cálculo dos tributos (PIS/COFINS e ICMS) deveria ser apenas o valor do custo de disponibilidade (ANEEL, 2014).

\subsection{CONSIDERAÇÕES FINAIS}

É necessária a criação de uma metodologia normatizada que permita identificar a expansão e os reforços de rede prudentes a serem efetuados a fim de receber a GD, sem afetar a modicidade tarifária e sem prejudicar a qualidade da energia. Um levantamento estatístico de quais consumidores tem o interesse de se conectar, bem como o momento em que isso deve ocorrer pode ser interessante de forma a nortear as distribuidoras no planejamento de sua expansão. A distribuidora deve possuir regras claras de prioridade para o atendimento de novos pedidos. Preventivamente, as redes devem ser reforçadas de forma a possibilitar a geração de GD a partir de fontes renováveis, respeitando os limites de operação, qualidade de energia e, sempre respeitando o princípio da modicidade tarifaria. Os prazos estabelecidos nas normas das distribuidoras e no PRODIST devem ser padronizados após a 
adoção de uma metodologia clara e uniforme. Uma regulamentação mais clara quanto ao Centro de Despacho de Geração Distribuída faz-se necessária, determinando como será feito o controle e o despacho dessa energia.

O sistema de compensação definido pela norma se mostra interessante no Brasil já que o custo da eletricidade tem aumentado ao longo do tempo, enquanto o valor para instalar sistemas fotovoltaicos faz o caminho inverso, diminuindo anualmente. No entanto, o retorno do investimento para o consumidor que aderir o sistema depende de muitos fatores que dificultam o cálculo se viabilidade do empreendimento. Estas dificuldades para estimar e verificar o retorno financeiro de sistemas de micro geração representam um entrave para o desenvolvimento do setor de energia solar fotovoltaica.

O financiamento da GD é um problema que o Governo precisa equacionar, de forma a viabilizar que os consumidores residenciais tenham interesse e meios de se tornar geradores. É necessário haver um sistema de remuneração especial, tal como as tarifas prêmio, até que se atinja a paridade tarifária, para que o investidor possa amortizar seu investimento em um tempo razoável.

A única forma da distribuidora comprar energia solar fotovoltaica em grande escala é se essa energia for vencedora de leilão. No entanto, como os custos da energia solar ainda são superiores aos das outras fontes de energia, principalmente a energia hidrelétrica e a eólica, a competição é inviável.

Sendo assim, uma solução para inserir essa fonte de maneira significativa no Brasil é por meio de leilões específicos de energia solar, nos quais os projetos solares competem somente entre si.

Leilões de energia específicos para energia fotovoltaica no país podem ser um mecanismo de incentivo aos investidores e à indústria nacional, contudo, não deixa de ser um tipo de subsídio, já que a competitividade dessa energia ainda é reduzida quando comparada a outras fontes.

O incentivo a indústria nacional é questão ainda a ser discutida, de forma que o desenvolvimento dessa tecnologia seja menos dependente do mercado externo e ainda possa criar novos empregos e renda para a população. 
Outro forma bastante discutida é a possibilidade de comercialização para a rede de excedentes de geração dos micro e mini geradores. Investidores argumentam que se pudessem vender seu excedente, no lugar de ganhar somente créditos de energia como atualmente, já teriam realizado novos investimentos. Em vários países, o micro e mini gerador são considerados produtores independentes de energia, permitindo-se, assim, a venda de seus excedentes líquidos de produção. Nesse sentido, é necessário desenvolver mecanismos específicos de comercialização do excedente, e oferecer incentivos à difusão que estimulem a compra de equipamentos que até então possuem pequena escala de produção e baixa viabilidade econômica. 


\section{CONCLUSÕES E SUGESTÕES}

\subsection{CONCLUSÕES DO TRABALHO}

A demanda por energia no Brasil está diretamente relacionada ao crescimento econômico e aumento de maneira substancial. A diversificação da matriz energética com fontes de energia renovável é uma tendência global e o Brasil já tem tomado medidas que proporcionam a inserção de novas fontes. A energia solar vem ao encontro desse objetivo como fonte de energia abundante, renovável, não poluente, e, sobretudo, disponível em todo o planeta. Duas formas de explorar esse recurso são abordadas: a geração centralizada e por meio da geração distribuída. A GD vem tomando importante espaço no mundo, principalmente, em países mais desenvolvidos que já exploraram muitas das suas reservas.

O uso de leilões de energia é um mecanismo interessante para promover a inserção da energia fotovoltaica no país. No entanto, ele deve ser estudado com cautela para produzir os efeitos esperados. Os resultados deste trabalho mostraram que esses leilões específicos para a fonte solar são a opção econômica mais atrativa no caso do setor elétrico brasileiro, já que produzem custos menores para a sociedade. Com as premissas adotadas por este trabalho, o subsídio que o governo brasileiro deu ao leilão específico de 2014 para a energia solar foi de 2,4 bilhões de reais. No entanto, se taxas de juros mais baixas fossem disponibilizadas, valores menores que $6 \%$, a GD poderia se tornar uma opção mais favorável à sociedade brasileira, quando comparada aos leilões específicos de energia solar.

Uma forma de viabilizar tal financiamento seria disponibilizar recursos dos diversos programas voltados a fontes renováveis alternativas, como o Fundo Clima e o Finem Fontes Alternativas para pessoas físicas.

O sucesso da implantação de um programa de geração distribuída de energia através de fonte solar fotovoltaica depende, sobretudo, da criação de condições mínimas de segurança para os investidores. Um passo para o desenvolvimento dessa tecnologia no Brasil foi a publicação da Resolução Normativa n482/2012 pela ANEEL e em seguida das normas técnicas pelas distribuidoras buscando definir os parâmetros para ligação da GD. A adoção 
do sistema de compensação (net metering) não envolve a necessidade de recursos financeiros de incentivo, tão somente de regulamentação dos requisitos técnicos de geração e de conexão, além da obrigatoriedade da distribuidora adquirir a energia gerada pela unidade geradora. Esse tipo de geração pode aliar economia financeira, consciência socioambiental e autossustentabilidade ao setor de energia elétrica.

Ao analisar a Norma publicada pelas distribuidoras, percebeu-se que é cabível a realização de mais estudos e melhorias de forma a tornar claro e homogêneo todo o processo de conexão dos geradores distribuídos nas áreas de concessão de cada distribuidora. É necessário que exista uma uniformização dos padrões e prazos de conexão, de forma a tornar claras as exigências ao investimento em GD.

A paridade tarifária ou algum outro tipo de subsídio à implantação de GD criará um ambiente favorável para o crescimento do número de interessados. As mudanças mais prementes na regulação existente são a abertura de linhas de crédito específicas e vantajosas para o micro e mini gerador e a redução de tributos. Uma medida de incentivo seria ofertar financiamento em condições atraentes para a instalação de mini ou micro geração.

A questão tributária ainda é uma das principais barreiras ao desenvolvimento do segmento de geração distribuída fotovoltaica no país. A cobrança do ICMS pelos estados e a alta carga sobre os equipamentos ainda deixam essa modalidade de geração com um alto preço. Uma medida simples para promover a geração distribuída seria reduzir a incidência de tributos sobre a atividade, pois não faz sentido propor subsídios e em seguida tributar a mesma atividade subsidiada. É necessário assegurar que a energia compensada não seja tributada, não só pelo ICMS, mas também pelo PIS/PASEP e COFINS e por qualquer outro tributo.

Apesar de os primeiros passos terem sido trilhados pela Resolução no 482/2012, ainda há um conjunto de iniciativas que precisam ser executadas por meio de políticas públicas bem coordenadas para que a geração distribuída ocupe um espaço relevante no Brasil. Enquanto essas barreiras não forem solucionadas, o leilão específico é a maneira de inserção da energia solar fotovoltaica na matriz elétrica brasileira com menos curto para a sociedade. 


\subsection{RECOMENDAÇÕES PARA PESQUISAS FUTURAS}

Muitos estudos relevantes podem ser realizados de forma a aprimorar o conteúdo deste trabalho. Dessa forma, são apresentadas sugestões trabalhos futuros.

1. Avaliação econômica do investimento em GDFV para o consumidor residencial que tome um empréstimo subsidiado, levando em consideração os impostos que podem ser ou não cobrados pelos estados e municípios.

2. Estudo do impacto de outros incentivos fiscais sobre a paridade tarifária, apontando $\mathrm{o}(\mathrm{s})$ mais apto(s) a produzir efeitos positivos em menor tempo.

3. Estudo que demonstre os efeitos de incentivos fiscais por governos locais em aspectos tais como geração de empregos, aumento de arrecadação, benefícios sociais diversos etc.

4. Estudo do impacto financeiro dos leilões específicos de energia solar na tarifa do consumidor cativo brasileiro.

5. Estudo de como a geração solar fotovoltaica distribuída contribui para a diminuição da demanda no horário de ponte de determinada área de concessão. 


\section{REFERÊNCIAS BIBLIOGRÁFICAS}

AMÉRICA DO SOL. Mineirão solar. Disponível em:

<http://www.americadosol.org/mineirao-solar/ >. Acesso em: agosto de 2014.

ABRADEE - Associação Brasileira de Distribuidores de Energia Elétrica. Tarifas de energia. Disponível em: <http://www.abradee.com.br/setor-de-distribuicao/tarifas-deenergia/tarifas-de-energia >. Acesso em: dezembro de 2014.

ABREU, Y. V.; OLIVEIRA, M. A. G.; GUERRA A, S. M. G. Energia, Economia, Rotas tecnológicas. Textos selecionados. Málaga, Espanha: Eumed.Net, Universidad de Málaga, 2010a.

ABREU, Y. V.; OLIVEIRA, M. A. G.; GUERRA, S. M. G. Energia, Sociedade e Meio Ambiente. Brasil, 2010b.

AFONSO, G. S. (2012). Análise dos Instrumentos Normativos de Suporte à Geração Solar Fotovoltaica Distribuída Conectada à Rede de Distribuição. Dissertação de Mestrado em Engenharia Elétrica, Publicação PPGENE.DM - 489/2012, Departamento de Engenharia Elétrica, Universidade de Brasília, Brasília, DF, 146p.

ANEEL - Agência Nacional de Energia Elétrica. Resolução Normativa ANEEL $n^{\circ} 482$, de 17 de abril de 2012. Estabelece as condições gerais para o acesso de microgeração e minigeração distribuída aos sistemas de distribuição de energia elétrica, o sistema de compensação de energia elétrica, e dá outras providências. Disponível em: <http://www.aneel.gov.br>. Acesso em: dezembro de 2013.

Cadernos Temáticos ANEEL. Micro e Minigeração Distribuída e Sistema de Compensação de Energia Elétrica. Março, 2014. Disponível em: < http://www.aneel.gov.br/biblioteca/downloads/livros/caderno-tematicomicroeminigeracao.pdf $>$. Acesso em agosto de 2014a.

. Relatórios do Sistema de Apoio a Decisão: Consumidores, Consumo, Receita e Tarifa Média - Classe de Consumo. Disponível em: < http://relatorios.aneel.gov.br/_layouts/xlviewer.aspx?id=/RelatoriosSAS/RelSampClasseC ons.xlsx\&Source=http://relatorios.aneel.gov.br/RelatoriosSAS/Forms/AllItems.aspx\&Defa ultItemOpen=1 >. Acesso em: outubro de 2014b.

Banco de Informações de Geração. Brasília, ANEEL, 2014. Disponível em: <http://www.aneel.gov.br>. Acesso em: janeiro de 2015.

BMU - Federal Ministry for the Environment, Nature Conservation and Nuclear Safety. Electricity from renewable energy sources - What does it cost?.Berlim, Alemanha: BMU, 2012. Disponível em: 〈http://www.bmu.de/english/aktuell/4152.php〉. Acesso em: 17 ago 2012. 
BNDES - Banco Nacional de Desenvolvimento Econômico e Social. Condições de Apoio Financeiro ao Segmento de Geração de Energia Solar - Leilão 2014. Disponível em: < http://www.bndes.gov.br/SiteBNDES/bndes/bndes_pt/Areas_de_Atuacao/Infraestrutura/Energia/Le ilao_Energia/energia_solar_2014.html>. Acesso em: janeiro de 2015.

BP - British Petroleum. Statistical Review of World Energy. (2014). Disponível em: <bp.com/statisticalreview>. Acesso em: janeiro de 2015.

BRASIL. Constituição da República Federativa do Brasil de 1988, de 5 de outubro de 1988.

Lei $\mathrm{n}^{\circ}$ 8.987, de 13 de fevereiro de 1995a. Disponível em: <http://www.planalto.gov.br>. Acesso em: setembro de 2014.

Lei no 9.074, de 07 de julho de 1995b. Disponível em: <http://www.planalto.gov.br>. Acesso em: setembro de 2014.

Lei no 9.427, de 26 de dezembro de 1996. Disponível em: <http://www.planalto.gov.br>. Acesso em: setembro de 2014.

Lei $\mathrm{n}^{\circ}$ 9.478, de 06 de agosto de 1997. Disponível em: <http://www.planalto.gov.br>. Acesso em: setembro de 2014.

Lei $\mathrm{n}^{\circ} 10.438$, de 26 de abril de 2002. Disponível em: <http://www.planalto.gov.br>. Acesso em: setembro de 2014.

Decreto $\mathrm{n}^{\circ}$ 5.025, de 30 de março de 2004a. Disponível em: <http://www.planalto.gov.br>. Acesso em: setembro de 2014.

Lei $\mathrm{n}^{\circ} 10.847$, de 15 de março de 2004b. Disponível em: <http://www.planalto.gov.br>. Acesso em: setembro de 2014.

Lei $\mathrm{n}^{\circ} 10.848$, de 15 de março de 2004c. Disponível em: <http://www.planalto.gov.br>. Acesso em: setembro de 2014.

Decreto 6.263, de 21 de novembro de 2007.

Institui o Comitê Interministerial sobre Mudança do Clima - CIM, orienta a elaboração do Plano Nacional sobre Mudança do Clima, e dá outras providências. Disponível em <www.planalto.gov.br>. Acesso em: setembro de 2014.

Lei ${ }^{\circ} 12.783$, de 11 de janeiro de 2013. Disponível em:

<http://www.planalto.gov.br>. Acesso em: dezembro de 2014. 
CAMARGO, R. S. C. (2013). Análise técnica de impactos e limite de penetração da geração distribuída fotovoltaica em uma rede radial de distribuição - Estudo de caso para o alimentador da embaixada da Itália em Brasília. Trabalho de Conclusão de Curso em Engenharia Elétrica, 2013, Departamento de Engenharia Elétrica, Universidade de Brasília, Brasília, DF, 220p.

CEB - Companhia Elétrica de Brasília. Norma técnica de distribuição nº.09: Requisitos para conexão de acessantes ao sistema de distribuição CEB-D - conexão em baixa e média tensão, publicada em dezembro de 2012. Disponível em:

<http://www.ceb.com.br/index.php/normas-normas-21 >. Acesso em julho de 2014.

CCEE - Câmara de Comercialização de Energia Elétrica. Preço de liquidação das diferenças. Disponível em:

$<$ http://www.ccee.org.br/portal/faces/pages_publico/inicio?_afrLoop=411963281052653\# $\% 40 \% 3 F$ afrLoop\%3D411963281052653\%26_adf.ctrl-state\%3Duyselxl1q_4> . Acesso em: janeiro de 2015 .

COUTURE, T., GAGNON, Y. (2010). An analysis of feed-in tariff remuneration models: Implications for renewable energy investment. Energy Policy, 38,955-968. Doi 10.1016/j.enpol.2009.10.047.

DEUTSCHE BANK GROUP - DB Climate Change Advisors: The German Feed-in-Tariff for PV, 2011. Disponível em: 〈https://www.db.com/cr/en/docs/German_FIT_for_PV.pdf $>$.

The German Feed-in-Tariff: Recent Policy Changes, 2012. Disponível em : < https://www.dbresearch.com/PROD/DBR_INTERNET_ENROD/PROD000000000029437 6/The+German+Feed-in+Tariff\%3A+Recent+Policy+Changes.PDF > .

EIA - U.S. Energy Information Administration. Annual Energy Outlook 2013 (modificado). Disponível em: http://www.eia.gov/forecasts/aeo/. Acesso em: agosto de 2014.

EPE - Empresa de Pesquisa Energética. Análise da Inserção da Geração Solar na Matriz Elétrica Brasileira. EPE, 2012. Disponível em: 〈www.epe.gov.br〉. Acesso em: junho de 2014.

Leilões. Disponível em http://www.epe.gov.br/Lists/Leilao/AllItems.aspx Acesso em: agosto de 2014a.

Apresentação sobre energia solar da EPE para ABINEE. Disponível em: $\langle$ http://www.abinee.org.br/informac/arquivos/ >. Acesso em: dezembro de 2014b. 
EPIA - European Photovoltaic Industry Association. Global Market Outlook For Photovoltaics 2013-2017. 2013. Disponível em < http://www.epia.org/news/publications/ >. Acesso em: dezembro de 2013.

. Global Market Outlook For Photovoltaics 2014-2018. 2014. Disponível em < http://www.epia.org/news/publications/ >. Acesso em: dezembro de 2014.

ESPANHA. Real Decreto n. 661, 25 de maio de 2007. Por el que se regula laactividad de producción de energia eléctrica em régimen especial. Boletin Oficial del Estado, Madri, Espanha, n. 126, p. 22846-22886, 26 de maio de 2007. Disponível em: <www.boe.es〉. Acesso em: agosto de 2014.

Real Decreto n. 1578, 26 de setembro de 2008. De retribución de laactividad de producción de energia eléctrica mediante tecnologia solar fotovoltaica para instalaciones posteriores a la fecha limite de mantenimiento de laretribucióndel Real Decreto 661/2007, de 25 de mayo, para dichatecnología. Boletin Oficial del Estado, Madri, Espanha, n. 234, p. 39117-39125, 27 de setembro de 2008. Disponível em: 〈www.boe.es〉. Acesso em: agosto de 2014.

Real Decreto n. 1565, 19 de novembro de 2010. Por el que se regulan y modifican determinados aspectos relativos a laactividad de producción de energia eléctrica em régimen especial. Boletin Oficial del Estado, Madri, Espanha, n. 283, p. 97428-97446, 23 de novembro de 2010. Disponível em: <www.boe.es>. Acesso em: agosto de 2014.

. Real Decreto Lei n. 1, 27 de janeiro de 2012. Por el que se procede a lasuspensión de los procedimentos de preasignación de retribución y a lasupresión de los incentivos económicos para nuevasinstalaciones de producción de energia eléctrica a partir de cogeneratión, fuentes de energia renovables y residuos. Boletin Oficial del Estado, Madri, Espanha, n. 24, p. 8068-8072, 28 de janeiro de 2012. Disponível em: <www.boe.es>. Acesso em: agosto de 2014.

EUROPE'S ENERGY PORTAL (2014). Disponível em: <http://www.energy.eu/\#renewable>.

EU - European Commission. The support of electricity from renewable energy sources, 2008. Disponível em:

<http://ec.europa.eu/energy/climate_actions/doc/2008_res_working_document_en.pdf>.

FERREIRA, A. A. (2013). Determinação do Limite de Penetração da Geração Distribuída Fotovoltaica em Alimentadores Radiais considerando Recursos de Manobra. Trabalho de Conclusão de Curso em Engenharia Elétrica, 2013, Departamento de Engenharia Elétrica, Universidade de Brasília, Brasília, DF, 178p. 
FIRST SOLAR. World's Largest Operational Solar Pv Project, Agua Caliente, Achieves 250 Megawatts Of Grid-Connected Power, 2012. Disponível em:

<http://investor.firstsolar.com>. Acesso em julho de 2014.

Topaz Solar Farm. 2014. Disponível em: < http://www.firstsolar.com/en/aboutus/projects/topaz-solar-farm >.Acesso em janeiro de 2015.

ISE - Fraunhofer Institute for Solar Energy Systems. Photovoltaics Report, 2014. Disponível em: < http://www.ise.fraunhofer.de>. Acesso em: Agosto de 2014.

GUEDES, L.M. (2013). Alocação de Unidades de Geração Distribuída Considerando Perdas e Aspectos Econômicos. Tese de doutorado em Engenharia Elétrica, Publicação 075/2013, Departamento de Engenharia Elétrica, Universidade de Brasília, Brasília, DF, $112 \mathrm{p}$.

GREENTECHMEDIA, 2014. New York Launches Major Regulatory Reform for Utilities. Disponível em: < http://www.greentechmedia.com/articles/read/new-york-launches-majorregulatory-reform-for-utilities >. Acesso em dezembro de 2014.

IEA - International Energy Agency. World Energy Outlook 2010. (2010). Acesso em: junho de 2014.

. Solar Energy Perspectives. (2011). Disponível em: <

http://www.iea.org/publications/freepublications/publication/Solar_Energy_Perspectives20 11.pdf>. Acesso em: outubro de 2014.

World Energy Outlook 2013. (2013a). Disponível em: <http://www.iea.org/>. Acesso em: junho de 2014.

Key World Energy Statistics. (2013b). Disponível em: <http://www.iea.org/>. Acesso em: junho de 2014.

IEA-PVPS- International Energy Agency - Photovoltaic Power Systems Programme. Trends in photovoltaic applications: Survey report of selected IEA countries between 1992 and 2005. (2006) Report IEA-PVPS T1-20:2006. Disponível em: <www.iea-pvps.org>. Acesso em: setembro de 2014.

Trends in Photovoltaic Applications: Survey Report of Selected IEA Countries Between 1992 and 2008. (2009) Report IEA-PVPS T1-20:2009. Disponível em: <www.iea-pvps.org>. Acesso em: junho de 2014.

Trends in photovoltaic applications: Survey report of selected IEA countries between 1992 and 2010. (2010) Report IEA-PVPS T1-20:2011. Disponível em: <www.iea-pvps.org>. Acesso em: junho de 2014. 
Trends 2013 in Photovoltaic Applications. (2013) Report IEA-PVPS T1-23:2013.

Disponível em: <www.iea-pvps.org>. Acesso em: dezembro 2013.

. Annual report 2013 (2014a). Report IEA-PVPS T1-20:2014. Disponível em:

<www.iea-pvps.org>. Acesso em: maio de 2014.

A Snapshot of Global PV 1992 - 2013. (2014b) Report IEA-PVPS T1-24:2014.

Disponível em: <www.iea-pvps.org>. Acesso em: junho de 2014.

ISES - International Solar Energy Society. Whitepaper: Transitioning to a Renewable Energy Future.2008. Disponível em: <http://whitepaper.ises.org.> Acesso em: junho de 2014.

JANNUZZI, G. de M.; MELO, C. A.(2013). Grid-connected photovoltaic in Brazil:

Policies and potencial impacts for 2030. Energy for Sustainable Development, 17, 40-46.

Doi 10.1016/j.esd.2012.10.010.

JUNQUEIRA, F. S. (2013). Planejamento de Redes de Distribuição Considerando Geração Distribuída. Dissertação de Mestrado em Engenharia Elétrica, Publicação PPGEE.DM-536/2013, Departamento de Engenharia Elétrica, Universidade de Brasília,

Brasília, DF, 116p.

MALAGUETA, D.; SZLO, A.; BORBA, B. S. M. C.; SORIA. R.; ARAGÃO, R.; SCHAEFFER, R.; DUTRA, R. (2013). Assessing incentive policies for integrating centralized solar power generation in the Brazilian electric power system. Energy Policy, 59, 198-212. Doi 10.1016/j.enpol.2013.03.029. Disponível em:

<http://www.sciencedirect.com/science/article/pii/S0301421513001833 >. Acesso em: dezembro de 2013.

MDIC - Ministério do Desenvolvimento, Indústria e Comércio Exterior. Plano Brasil Maior. 2011

MITSCHER, M.; RUTHER, R. (2012). Economic performance and policies for gridconnected residential solar photovoltaic systems in Brazil. Energy Policy, 49, 688-694. Doi 10.1016/j.enpol.2012.07.009.

MME - Ministério de Minas e Energia. Relatório do Grupo de Trabalho de Geração Distribuída em Sistemas Fotovoltaicos - GT - GDSF. Brasília: MME, 2009. Disponível em <www.mme.gov.br>. Acesso em: julho de 2014.

MME - Ministério de Minas e Energia, EPE - Empresa de Pesquisa Energética. Plano Nacional de Energia - 2030. Rio de Janeiro, MME/EPE, 2008. Disponível em <www.mme.gov.br>. Acesso em: julho de 2014. 
Balanço Energético Nacional 2009: Ano Base: 2008. Rio de Janeiro, MME/EPE, 2009. Disponível em <www.mme.gov.br>. Acesso em: julho de 2014.

Plano Decenal de Expansão de Energia 2014 - 2023. Brasília, MME/EPE, 2014. Disponível em <www.mme.gov.br>. Acesso em: julho de 2014.

Plano Decenal de Expansão de Energia 2012 - 2021. Brasília, MME/EPE, 2012. Disponível em <www.mme.gov.br>. Acesso em: julho de 2014.

. Balanço Energético Nacional 2013: Ano Base: 2012. Rio de Janeiro, MME/EPE, 2013a. Disponível em <www.mme.gov.br>. Acesso em: julho de 2014.

Plano Decenal de Expansão de Energia 2013 - 2022. Brasília, MME/EPE, 2013b. Disponível em <www.mme.gov.br>. Acesso em: julho de 2014.

Balanço Energético Nacional 2014: Ano base 2013 - Relatório Síntese. Rio de Janeiro: MME/EPE, 2014a. Disponível em <www.mme.gov.br>. Acesso em: julho de 2014.

Plano Decenal de Expansão de Energia 2014 - 2023. Brasília, MME/EPE, 2014b. Disponível em <www.mme.gov.br>. Acesso em: julho de 2014.

MOVILLA, S., MIGUEL, L. J., BLÁZQUEZ, L. F.: A system dynamics approach for the photovoltaic energy market in Spain .2013 Disponível em: < http://www.sciencedirect.com/science/article/pii/S030142151300325X >. Acesso em: dezembro de 2013.

NCA - National Climate Assessment. Climate Change Impacts in the United States. 2014 Disponível em: 〈 http://nca2014.globalchange.gov/ >. Acesso em: dezembro de 2014.

OLIVEIRA, M. S. Orientações Metodológicas para Monografias de Lato Sensu. Lavras, MG, 2007.

PRADO, T. G. F. Políticas Públicas e Programas de Desenvolvimento Energético com Foco em Energias Renováveis no Brasil: do Planejamento Setorial de Infraestrutura em Energia às Perspectivas de Mudanças Globais para o Acesso e Uso de Recursos Energéticos. Tese de Doutorado, Departamento de Engenharia Elétrica, Faculdade de Tecnologia, Universidade de Brasília. Brasília, 2014.

PROINFA - Programa de Incentivo às Fontes Alternativas de Energia Elétrica. Publicações. Disponível em: < http://www.mme.gov.br/programas/proinfa>. Acesso em: agosto de 2014.

QUASCHNING, V.; Renewable Energy and Climate Change. John Wiley \& Sons, 2011. 
REN21 - Renewable Energy Policy Network for the $21^{\text {st }}$ Century. Renewables interactive map. Disponível em : < http://map.ren21.net/\#fr-FR/search/by-technology/4,15,14,29 > Acesso em: julho de 2013.

Global Status Report 2013. (2013) Disponível em : <

http://www.ren21.net/ren21activities/globalstatusreport.aspx > Acesso em: julho de 2014.

Global Status Report 2014. (2014) Disponível em : <

http://www.ren21.net/REN21Activities/GlobalStatusReport.aspx $>$ Acesso em: julho de 2014.

RENI - Renewables Insight. PV Power Plants 2012. Disponível em:

<http://www.renewablesinsight.com>. Acesso em 12 de fevereiro de 2012.

ROSS, Stephen A.; WESTERFIELD, Randolph W.; JAFFE, Jeffrey F. Administração financeira. São Paulo: Editora Atlas, 1995.

RÜTHER, R.; ZILLES, R. Making the case for grid-connected photovoltaics in Brazil. Energy Policy, v. 39, p. 1027-1030, 2011.

SARASA-MAESTRO, C.J., DUFO-LOPES, R., BERNAL-AGUSTIN, J.L.; Photovoltaic remuneration policies in the European Union. 2013. Disponível em: < http://www.sciencedirect.com/science/article/pii/S0301421512010567 >. Acesso em: dezembro de 2013.

SEVERINO, M. M. (2008). Avaliação técnico-Econômica de um sistema Híbrido de geração Distribuída Para Atendimento a Comunidades Isoladas Da Amazônia. Tese de Doutorado em Engenharia Elétrica, Publicação PPGENE.TD-027/08. Departamento de Engenharia Elétrica, Faculdade de Tecnologia, Universidade de Brasília. Brasília, DF, $335 p$.

SHAYANI, R.A.; de OLIVEIRA, M.A.G.,

"Photovoltaic Generation Penetration Limits in Radial DistributionSystems",

Power Systems, IEEE Transactions on , vol.26, no.3, pp.1625,1631, Aug. 2011.

SHAYANI, R. A. (2010). Método para Determinação do Limite de Penetração da Geração Distribuída Fotovoltaica em Redes Radiais de Distribuição. Tese de Doutorado em Engenharia Elétrica, Publicação PPGENE.TD-051/10, Departamento de Engenharia Elétrica, Universidade de Brasília, Brasília, DF, 161p.

SOLARGIS. Disponível em : < http://solargis.info/doc/free-solar-radiation-maps-GHI $>$. Acesso em: dezembro de 2013. 
SPE - Secretaria de Política Econômica. Disponível em: <

https://www1.fazenda.gov.br/spe/novo_site/home/panorama_economia.html >. Acesso em: março de 2014.

SECRETARIA DO TESOURO NACIONAL - Relatório Mensal da Dívida Pública

Federal - Outubro/2014. Disponível em: < http://www.tesouro.fazenda.gov.br >. Acesso em: dezembro de 2014. 


\section{APÊNDICE A - RESULTADO DO $6^{\circ}$ LEILÃO DE ENERGIA DE RESERVA}

\section{A.1 FONTE SOLAR}

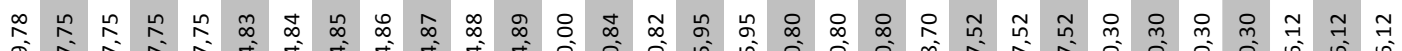
ปे

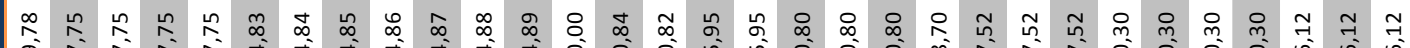

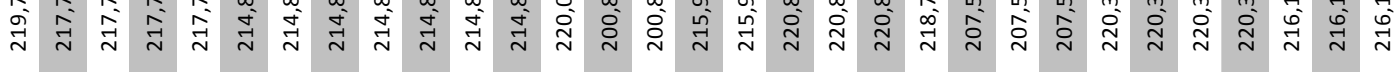

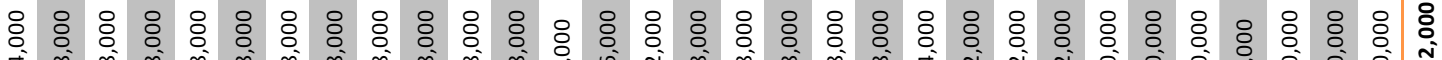

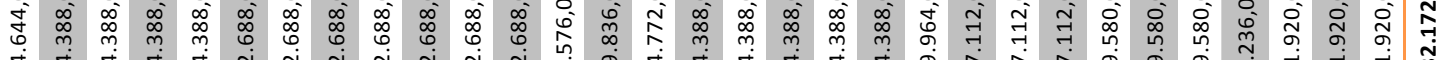

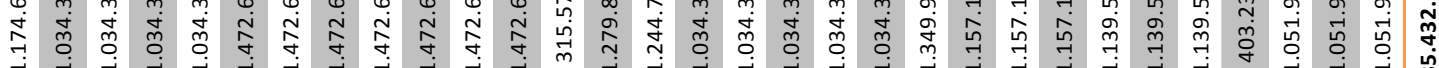

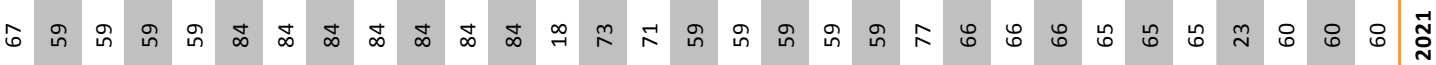

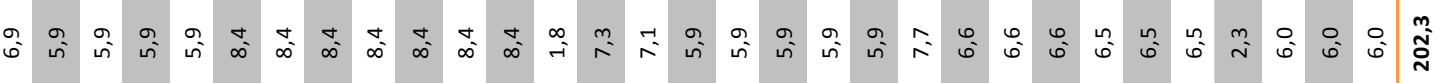

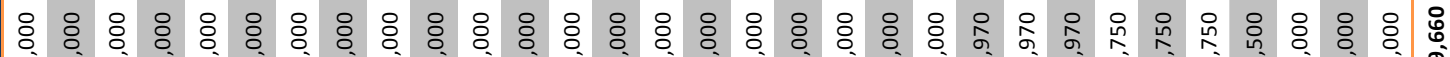

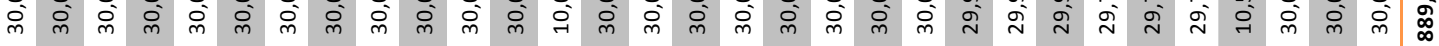

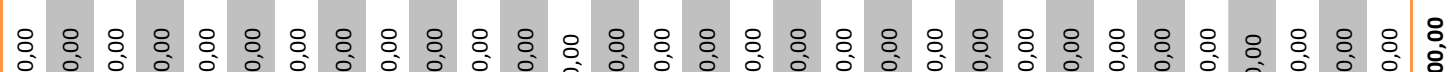
定

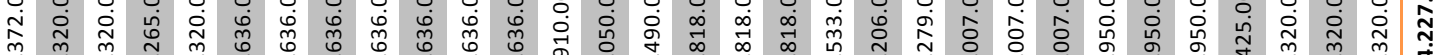
总

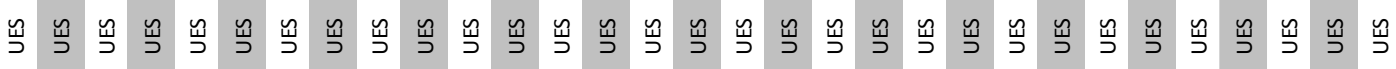

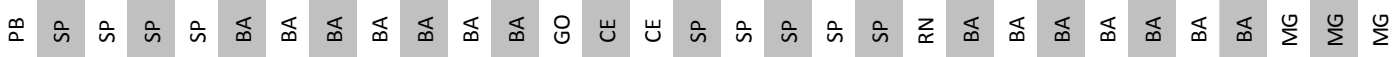

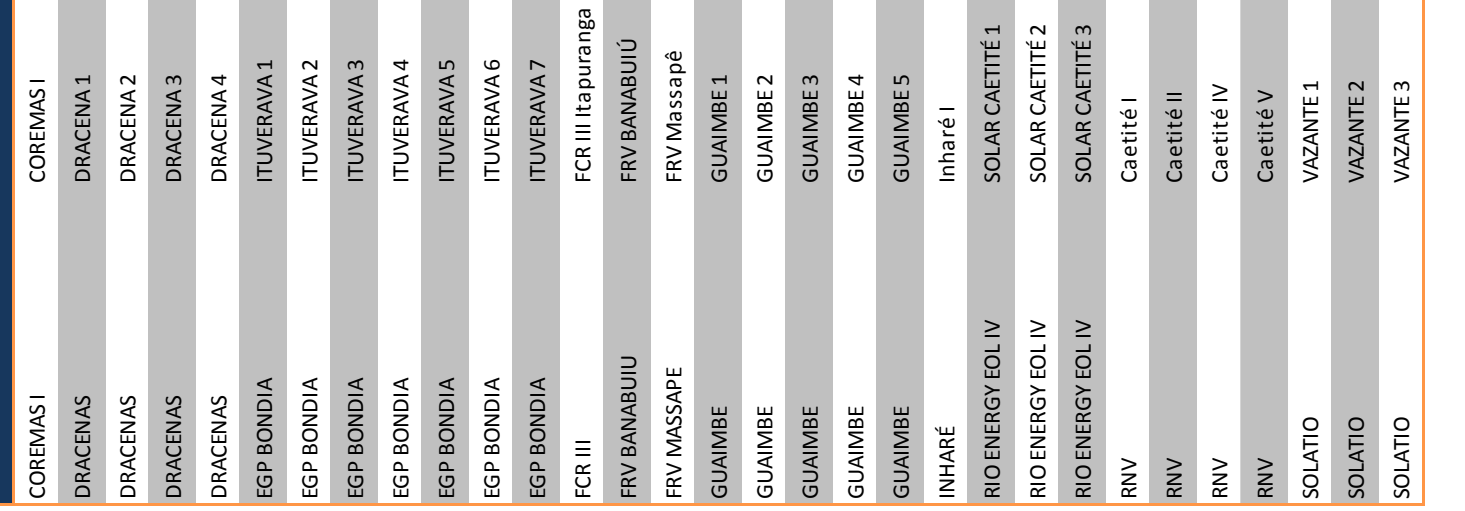




\section{A.2 FONTE EÓLICA}

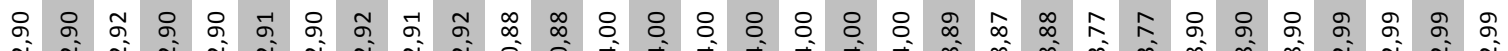

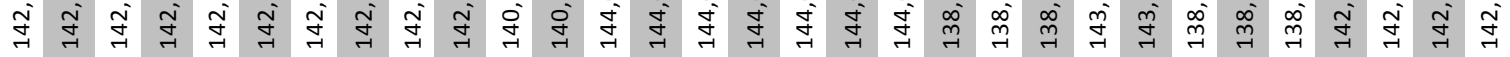

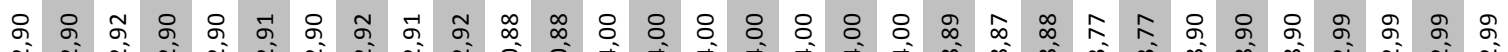

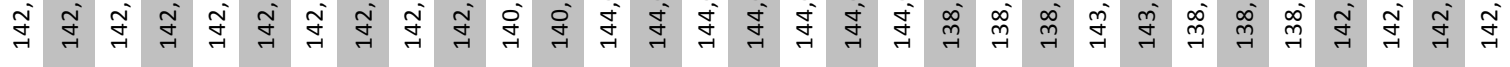

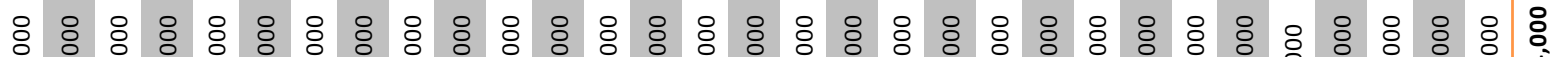

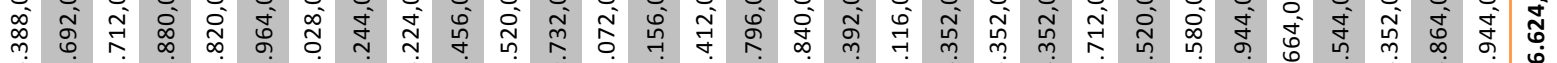

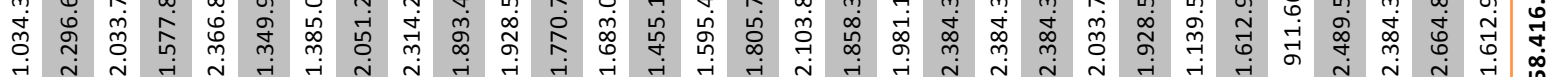
$\cos 0$

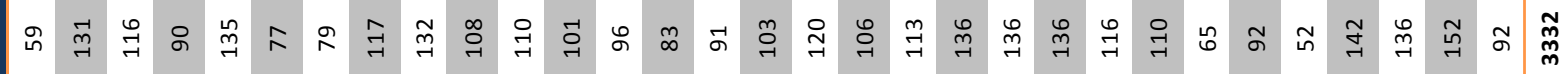

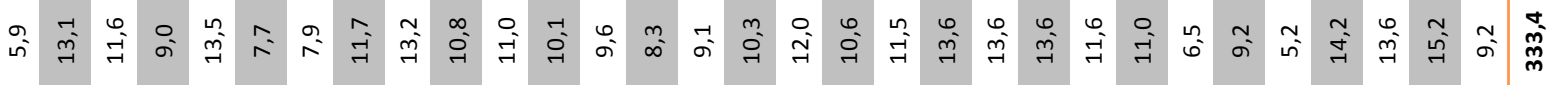
ه 웅 ป

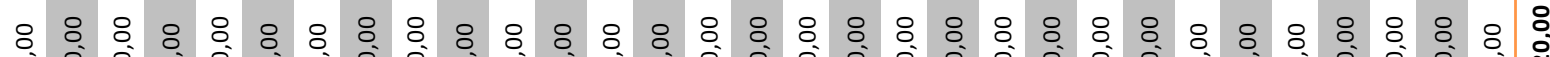

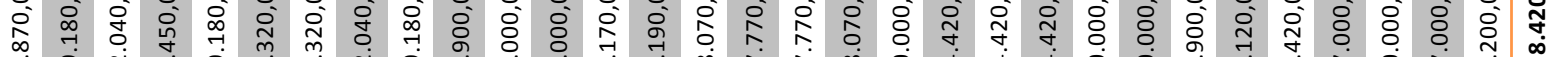

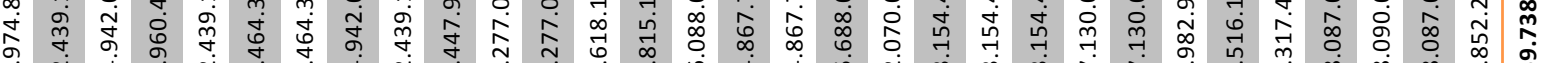

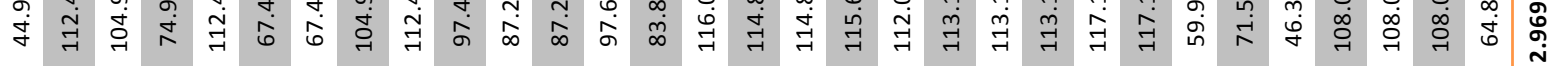

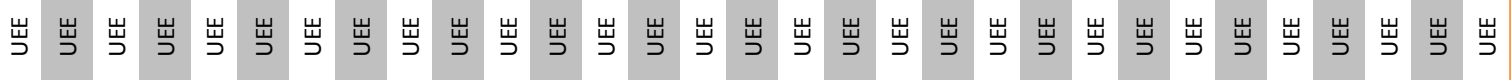

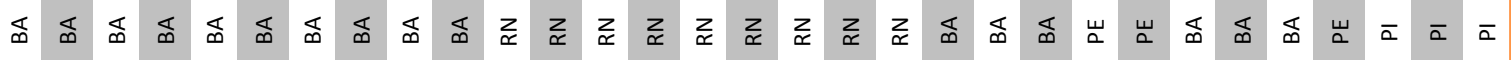

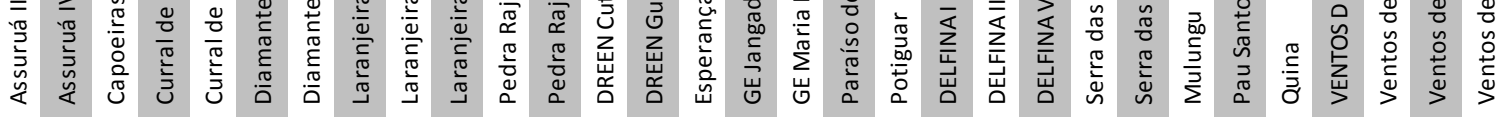


Potência (MWmédio)

1658,760

Garantia Física (MWmédio)

535,700

Total Contratado (MWmédio)

535,3

Preço Médio(R\$̦/MWmédio)

169,82

Total (MWh)

$93.848 .796,000$

Montante (R\$)

$15.937 .064 .344,44$ 